NUREG/CR-6283

CNWRA 94-017.

\title{
Field Site Investigation: Effect of Mine Seismicity on Groundwater Hydrology
}

Prepared by

G. I. Ofoegbu, S. Hsiung, A. H. Chowdhury/CNWRA

J. Philip/NRC

Center for Nuclear Waste Regulatory Analyses

Prepared for

U.S. Nuclear Regulatory Commission 


\section{AVAILABILITY NOTICE}

- Availability of Reférence Materials Cited in NRC Publications

Most documents cited In NRC publications will be available from one of the following sources:

1. The NRC Public Document Room, 2120 L Street, NW., Lower Level, Washington, DC 20555-0001

2. The Superintendent of Documents, U.S. Government Printing Office, P. O. Box 37082, Washington, DC 20402-9328

3. The National Technical Information Service, Springfield, VA 22161-0002

Although the llsting that follows represents the majority of documents cited in NRC publications, it is not intended to be exhaustive.

Referenced documents available for Inspection and copying for a fee from the NRC Public Document Room include NRC correspondence and internal NRC memoranda; NRC bulletins, circulars, information notices, inspection and investigation notices; licensee event reports; vendor reports and correspondence; Commission papers; and appllcant and licensee documents and correspondence.

The following documents in the NUREG series are available for purchase from the Government Printing Office: formal NRC staff and contractor reports, NRC-sponsored conference proceedings, international agreement reports, grantee reports, and NRC booklets and brochures. Also available are regulatory guides, NRC regulations in the Code of Federal Regulations, and Nuclear Regulatory Commission Issuances.

Documents avallable from the National Technical Information Service include NUREG-series reports and technical reports prepared by other Federal agencies and reports prepared by the Atomic Energy Commission, forerunner agency to the Nuclear Regulatory Commission.

Documents available from publlc and special technical libraries include all open literature items, such as books. journal articles, and transactions. Federal Register notices. Federal and State legislation, and congressional reports can usually be obtained from these libraries.

Documents such as theses, dissertations, foreign reports and translations, and non-NRC conference proceedings are avallable for purchase from the organization sponsoring the publication cited.

Single coples of NRC draft reports are available free, to the extent of supply, upon written request to the Office of Administration, Dlstribution and Mail Services Section, U.S. Nuclear Regulatory Commission, Washington, DC 20555-0001.

Coples of industry codes and standards used in a substantive manner in the NRC regulatory process are maintained at the NRC Library. Two White Flint North, 11545 Rockville Pike, Rockville, MD 20852-2738, for use by the public. Codes and standards are usually copyrighted and may be purchased from the originating organization or, if they are American National Standards. from the American National Standards Institute. 1430 Broadway, New York, NY 10018-3308.

\section{DISCLAIMER NOTICE}

This report was prepared as an account of work sponsored by an agency of the United States Government. Neither the United States Govemment nor any agency thereof, nor any of their employees, makes any warranty, expressed or implied, or assumes any legal liability or responsibility for any third party's use, or the results of such use, of any information, apparatus, product, or process disclosed in this report, or represents that its use by such third party would not infringe privately owned rights. 


\section{DISCLAIMER}

Portions of this document may be illegible in electronic image products. Images are. produced from the best available original document. 
NUREG/CR-6283

CNWRA 94-017

\section{Field Site Investigation: \\ Effect of Mine Seismicity on \\ Groundwater Hydrology}

Manuscript Completed: July 1994

Date Published: April 1995

Prepared by

G. I. Ofoegbu, S. Hsiung, A. H. Chowdhury/CNWRA

J. Philip/NRC

Center for Nuclear Waste Regulatory Analyses

6220 Culebra Road

San Antonio, TX 78238-5166

Prepared for

Division of Regulatory Applications

Office of Nuclear Regulatory Research

U.S. Nuclear Regulatory Commission

Washington, DC 20555-0001

NRC Job Code B6643 


\section{PREVIOUS REPORTS IN SERIES}

\begin{tabular}{|c|c|c|}
\hline Number & & Date Issued \\
\hline CNWRA 90-004 & $\begin{array}{l}\text { Qualification Studies on the Distinct Element Code } \\
\text { UDEC Against Some Benchmark Analytical Problems }\end{array}$ & January 1990 \\
\hline CNWRA 90-005 & $\begin{array}{l}\text { Development of a Rock Joint Dynamic Shear Test } \\
\text { Apparatus }\end{array}$ & January 1990 \\
\hline CNWRA 90-006 & $\begin{array}{l}\text { Qualification Studies on the Finite Element Code } \\
\text { HONDO II Against Some Benchmark Analytical } \\
\text { Problems }\end{array}$ & February 1990 \\
\hline NUREG/CR-5440 & $\begin{array}{l}\text { Critical Assessment of Seismic and Geomechanics } \\
\text { Literature Related to a High-Level Nuclear Waste } \\
\text { Underground Repository }\end{array}$ & June 1991 \\
\hline CNWRA 92-005 & $\begin{array}{l}\text { Thermo-Hydro-Mechanical Coupled Modeling: } \\
\text { Multiple Fracture Model, BMT2 } \\
\text { Coupled Stress - Flow Model, TC1 } \\
\text { DECOVALEX - PHASE I }\end{array}$ & April 1992 \\
\hline CNWRA $92-012$ & $\begin{array}{l}\text { Field Site Investigation: Effect of Mine Seismicity } \\
\text { on a Jointed Rock Mass }\end{array}$ & December 1992 \\
\hline CNWRA 93-002 & $\begin{array}{l}\text { Thermo-Hydro-Mechanical Coupled Modeling: } \\
\text { Near Field Repository Model, BMT3 } \\
\text { DECOVALEX - PHASE II }\end{array}$ & August 1993 \\
\hline CNWRA 93-013 & Laboratory Characterization of Rock Joints & September 1993 \\
\hline CNWRA 93-024 & $\begin{array}{l}\text { Evaluation of Rock Joint Models and Computer Code } \\
\text { UDEC Against Experimental Results }\end{array}$ & December 1993 \\
\hline
\end{tabular}




\begin{abstract}
The results of a field investigation on the groundwater-hydrologic effect of mining-induced earthquakes are presented in this report. The investigation was conducted at the Lucky Friday Mine, a silver-lead-zinc mine in the Coeur d'Alene Mining District of Idaho. The groundwater pressure in sections of three fracture zones beneath the water table was monitored over a 24 -mo period. The fracture zones were accessed through a 360-m-long inclined borehole, drilled from the 5,700 level station of the mine. The magnitude, source location, and associated ground motions of mining-induced seismic events were also monitored during the same period, using an existing seismic instrumentation network for the mine, augmented with additional instruments installed specifically for the project by the Center for Nuclear Waste Regulatory Analyses (CNWRA).
\end{abstract}

More than 50 seismic events of Richter magnitude 1.0 or larger occurred during the monitoring period. Several of these events caused the groundwater pressure to increase, whereas a few caused it to decrease. Generally, the groundwater pressure increased as the magnitude of seismic event increased; for an event of a given magnitude, the groundwater pressure increased by a smaller amount as the distance of the observation point from the source of the event increased. The data was examined using regression analysis. The statistical models obtained predicted the effects of small-magnitude seismic events more satisfactorily than those of larger ones. The observed change in groundwater pressure due to seismic events of magnitude 3.0 or more were larger than those predicted for similar seismic events using the statistical models.

Based on these results, it is suggested that the effect of earthquakes on groundwater flow may be better understood through mechanistic modeling. The mechanical processes and material behavior that would need to be incorporated in such a model are examined. They include a description of the effect of stress change on the permeability and water storage capacity of a fractured rock mass; transient fluid flow; and the generation and transmission of seismic waves through the rock mass. 
- + - 


\section{CONTENTS}

Section

Page

FIGURES $\ldots \ldots \ldots \ldots \ldots \ldots \ldots \ldots \ldots \ldots \ldots \ldots \ldots \ldots \ldots \ldots \ldots \ldots \ldots \ldots \ldots$

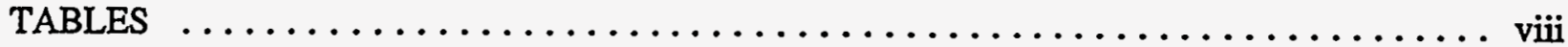

ACKNOWLEDGMENTS $\ldots \ldots \ldots \ldots \ldots \ldots \ldots \ldots \ldots \ldots \ldots \ldots \ldots \ldots$ ix

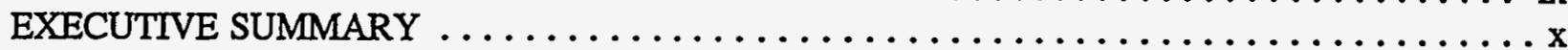

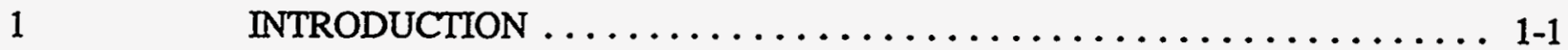

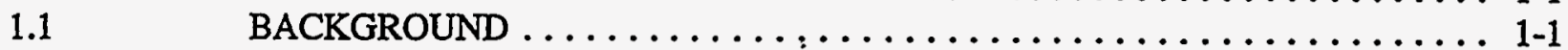

1.1.1 Mechanisms of Earthquake-Induced Hydrologic Changes . . . . . . . . . . 1-3

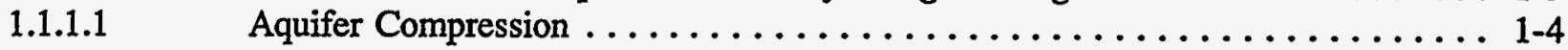

1.1.1.2 Change in Aquifer/Aquitard Permeability ................... 1-5

1.1.2 Numerical Modeling of Earthquake-Induced Hydrologic Changes . . . . . . . 1-5

1.1.2.1 Short-Term Changes Related to Seismic Waves ................ 1-5

1.1.2.2 Long-Term Changes Due to Aquifer Compression $\ldots \ldots \ldots \ldots \ldots \ldots \ldots$

1.1.2.3 Long-Term Changes Due to Change in Rock Mass Permeability . . . . . . . . 1-7

$1.2 \quad$ REGULATORY FRAMEWORK $\ldots \ldots \ldots \ldots \ldots \ldots \ldots \ldots \ldots \ldots \ldots \ldots$

$1.3 \quad$ SCOPE OF INVESTIGATION $\ldots \ldots \ldots \ldots \ldots \ldots \ldots \ldots \ldots \ldots \ldots \ldots \ldots \ldots$

1.4 SITE EVALUATION AND SELECTION $\ldots \ldots \ldots \ldots \ldots \ldots \ldots \ldots \ldots \ldots$

2 SITE DESCRIPTION (LUCKY FRIDAY MINE) $\ldots \ldots \ldots \ldots \ldots \ldots \ldots \ldots$ 2-1

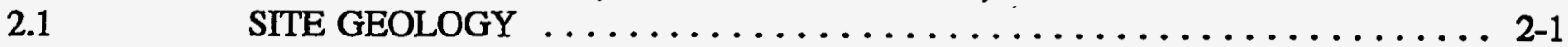

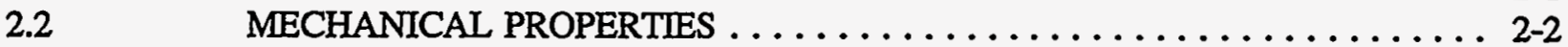

$3 \quad$ SEISMIC MONTTORING $\ldots \ldots \ldots \ldots \ldots \ldots \ldots \ldots \ldots \ldots \ldots \ldots \ldots \ldots$

3.1 MINE-WIDE SEISMIC INSTRUMENTATION $\ldots \ldots \ldots \ldots \ldots \ldots \ldots \ldots \ldots$. $\ldots \ldots \ldots$

3.2 ADDITIONAL SEISMIC INSTRUMENTATION $\ldots \ldots \ldots \ldots \ldots \ldots \ldots \ldots \ldots . \ldots$.

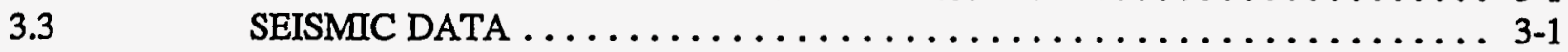

3.3.1 Determination of the Source Locations for the Macroseismic Events . . . . . . . 3-2

3.3.2 Determination of Peak Particle Velocity .................. 3-4

4 GROUNDWATER PRESSURE MONITORING ............. $4-1$

4.1 INSTRUMENTATION AND DATA ACQUISITION $\ldots \ldots \ldots \ldots \ldots \ldots \ldots$

4.2 CALIBRATION OF VIBRATING-WIRE PIEZOMETER $\ldots \ldots \ldots \ldots \ldots \ldots .4$

$4.3 \quad$ GROUNDWATER PRESSURE DATA $\ldots \ldots \ldots \ldots \ldots \ldots \ldots \ldots \ldots \ldots$

4.4 SHORT-TERM SEISMIC EFFECTS ON GROUNDWATER PRESSURE . . . . 4 4-10

$5 \quad$ CONCLUSION $\ldots \ldots \ldots \ldots \ldots \ldots \ldots \ldots \ldots \ldots \ldots \ldots \ldots \ldots \ldots \ldots$

$6 \quad$ REFERENCES $\ldots \ldots \ldots \ldots \ldots \ldots \ldots \ldots \ldots \ldots \ldots \ldots \ldots \ldots \ldots \ldots \ldots \ldots$

APPENDIX A LABORATORY DETERMINATION OF INTACT ROCK PROPERTIES

APPENDIX B $\quad$ ROCK QUALITY LOG FOR THE GROUNDWATER RESPONSE

BOREHOLE AND TYPICAL JOINT SURFACE PROPERTIES

APPENDIX C GROUNDWATER PRESSURE HISTORY PLOTS 


\section{FIGURES}

Figure

Page

1-1 Water level changes in a shaft at the Clayton Silver Mine, following the October 1983 Borah Peak earthquake (from Wood et al., 1985) . . . . . . . . . . . 1-3

2-1 Plan view of the Lucky Friday orebody showing fault traces $\ldots \ldots \ldots \ldots \ldots \ldots$

2-2 Estimation of in situ modulus of deformation from Norwegian Geotechnical Institute (NGI) and Council for Scientific and Industrial Research (CSIR) classification methods (from Board and Beus, 1989) . . . . . . . . . . . 2-4

3-1 Schematic diagram of seismic data acquisition system $\ldots \ldots \ldots \ldots \ldots \ldots \ldots \ldots$

3-2 Observed seismic events during $1991 \ldots \ldots \ldots \ldots \ldots \ldots \ldots \ldots \ldots \ldots \ldots$

3-3 Observed seismic events during $1992 \ldots \ldots \ldots \ldots \ldots \ldots \ldots \ldots \ldots \ldots \ldots$

4-1 Schematic drawing of straddle packer pair with piezometer enclosure . . . . . . . 4-2

4-2 Zones packed off for water pressure measurement along the borehole drilled from Lucky Friday Silver Shaft at a depth of $1,737 \mathrm{~m}$ below ground surface . . . . . . 4-3

4-3 Schematic diagram of piezometer data acquisition system . . . . . . . . . . 44

4-4 Summary of Zone 1 Hydraulic Head, January 1991 through December $1992 \ldots \ldots$. . . . 4 47

4-5 Summary of Zone 2 Hydraulic Head, January 1991 through December $1992 \ldots \ldots$. . . . 4-8

4-6 Summary of Zone 3 Hydraulic Head, January 1991 through December 1992 . . . . . . . . 4-9

4-7 Groundwater pressure history for Zone 1, September 18 through 20, $1991 \ldots$. . . . . . 4-11

48 Groundwater pressure history for Zone 2, September 18 through $20,1991 \ldots$. . . . . . 4-11

4-9 Groundwater pressure history for Zone 3, September 18 through $20,1991 \ldots \ldots$. . . . . 4 12

4-10 Groundwater pressure history for Zone 1, March 21 through April 10, $1991 \ldots$. . . . . 4 4-12

4-11 Groundwater pressure history for Zone 2, March 21 through April 10, $1991 \ldots$. . . . . 4-13

4-12 Groundwater pressure history for Zone 3, March 21 through April 10, $1991 \ldots$. . . . . 4-13

4-13 Scatter plot of change in groundwater pressure versus seismic event magnitude

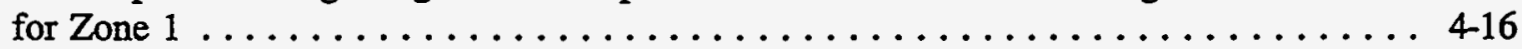

4-14 Scatter plot of change in groundwater pressure versus seismic event magnitude

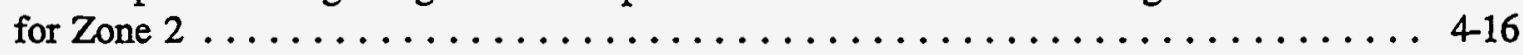

4-15 Scatter plot of change in groundwater pressure versus seismic event magnitude for Zone $3 \ldots \ldots \ldots \ldots \ldots \ldots \ldots \ldots \ldots \ldots \ldots \ldots \ldots \ldots \ldots \ldots \ldots$

4-16 Scatter plot of change in groundwater pressure versus seismic event magnitude, including data for all three zones $\ldots \ldots \ldots \ldots \ldots \ldots \ldots \ldots \ldots \ldots \ldots \ldots$ 4 $\ldots \ldots \ldots$

4-17 Scatter plot of change in groundwater pressure versus scaled source distance

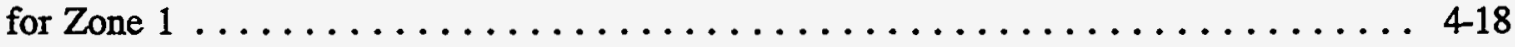

4-18 Scatter plot of change in groundwater pressure versus scaled source distance

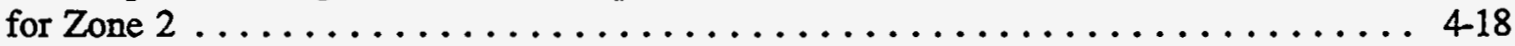

4-19 Scatter plot of change in groundwater pressure versus scaled source distance

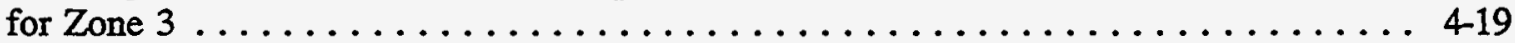

420 Scatter plot of change in groundwater pressure versus scaled source distance, including data for all three zones . . . . . . . . . . . . . . . . . . . 4-19

4-21 Measured versus predicted pressure head change for Zone 1, based on model described by Eq. (4-2) . . . . . . . . . . . . . . . . . . . . . . . . 4-20 


\section{FIGURES}

Figure

Page

4-22 Measured versus predicted pressure head change for Zone 2, based on model described by Eq. (4-2) ............................ 4 420

4-23 Measured versus predicted pressure head change for Zone 3, based on model described by Eq. (4-2) . . . . . . . . . . . . . . . . . . . . . 421

4-24 Measured versus predicted pressure head change for Zones 1, 2, and 3, combined, based on model described by Eq. (4-2) . . . . . . . . . . . . . . . . 4-21

4-25 Measured versus predicted pressure head change for Zone 1, based on model described by Eq. (4-3) . . . . . . . . . . . . . . . . . . . . . 4 4-23

4-26 Measured versus predicted pressure head change for Zone 2, based on model described by Eq. (4-3) . . . . . . . . . . . . . . . . . . . . . 4-23

4-27 Measured versus predicted pressure head change for Zone 3, based on model described by Eq. (4-3) . . . . . . . . . . . . . . . . . . . . . . . . 4-24

4-28 Measured versus predicted pressure head change for Zones 1, 2, and 3, combined,

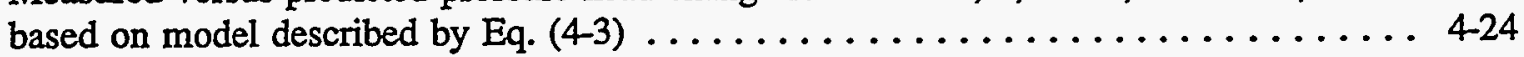




\section{TABLES}

Table

Page

2-1 Lucky Friday Mine material property data (from Pariseau and Moon, 1987) . . . . . . 2-3

2-2 Average rock properties by geologic formation (from Whyatt, 1986) $\ldots \ldots \ldots \ldots$

3-1 Seismic events which produced measurable changes in groundwater pressure $\ldots \ldots \ldots 3$

4-1 Coordinates of piezometer locations $\ldots \ldots \ldots \ldots \ldots \ldots \ldots \ldots \ldots \ldots \ldots \ldots$

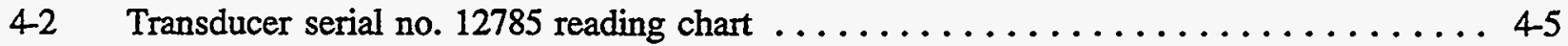

4-3 Comparison of calibration factors used for the four vibrating wire

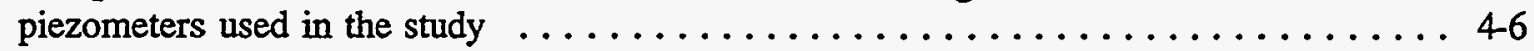

44 Values of initial reading and calibration factors of the piezometers . . . . . . . . . 4 46

4-5 Groundwater pressure changes associated with seismic events . . . . . . . . . . 4-15 


\section{ACKNOWLEDGMENTS}

The authors would like to express their appreciation to the management of Hecla Mining Company for providing access to the Lucky Friday Mine for the field study. The study would not have been possible without their permission and assistance. Appreciation also goes to the Spokane Research Center of the U.S. Bureau of Mines for its cooperation in permitting the use of its macro-seismic monitoring system for seismic signal data collections and in sharing data with the Center for Nuclear Waste Regulatory Analyses (CNWRA). The authors would like to acknowledge the contribution of Dr. B.H.G. Brady in the evaluation and selection of the site. The authors would like to thank Drs. Wesley C. Patrick and Vivek Kapoor for their technical review of the report. Thanks also go to Dr. S.D. McKinnon of Itasca Consulting Group, Inc., for his assistance with instrument installation; Mr. Mikko P. Ahola, and Drs. Amitava Ghosh and Wilson Blake for valuable assistance rendered at various stages of the project; and Dr. John Kemeny of the University of Arizona for his assistance with laboratory intact rock testing. The authors are also thankful to Ms. Rebecca A. Sanchez for skillful typing and formatting of the report, and to Mr. Jim Pryor and Mrs. Cathy Cudd, who provided a full range of expert editorial services in the preparation of the final document.

This report was prepared to document work performed by the CNWRA for the Nuclear Regulatory Commission (NRC) under Contract No. NRC-02-93-005. The activities reported here were performed on behalf of the NRC Office of Nuclear Regulatory Research, Division of Regulatory Applications. This report is an independent product of the CNWRA and NRC staffs, and does not necessarily reflect the views or regulatory position of the NRC.

\section{QUALITY OF DATA}

CNWRA-generated original data contained in this report meet quality assurance requirements described in the CNWRA Quality Assurance Manual. Sources for other data should be consulted for determining the level of quality for those data.

\section{SOFTWARE QUALTTY ASSURANCE}

The statistical analysis code S-PLUS was used for some of the analyses contained in this report. This code is commercially available; the CNWRA does not have access to its source code; therefore, it is not controlled under the CNWRA's Software Configuration Procedures. 


\section{EXECUTIVE SUMMARY}

This report presents the result of field studies on the nature and magnitude of hydrologic response generated by mining-induced small-magnitude earthquakes. The studies were conducted at the Lucky Friday Mine, a silver-lead-zinc mine located in Precambrian metasediments of the Coeur d'Alene Mining District in Idaho. The mine experiences frequent seismic activity as a result of slip on steeply dipping bedding or joint planes as well as rockbursts. Fluid flow in the rock mass is controlled by a series of fracture zones associated with major faults or mineralized veins. The water pressure in sections of three such fracture zones below the groundwater table was monitored over a 24 mo period. The magnitude, source location, and associated ground motion of seismic events at the mine were also monitored during the period.

The hydrologic effects of earthquakes are related to changes in the water conductivity and storage capacity of rocks, which result from rock deformations (opening or closure of pores and fractures) caused by stress changes associated with the earthquake. The effects include changes in groundwater pressure and discharge rate through springs, wells, and streams. Some earthquake-induced hydrologic responses develop and dissipate rapidly (within a matter of hours or a few days following the earthquake), and are believed to be caused by changes induced directly by the seismic waves; these are referred to as the short-term response. The others, known as the long-term response, develop more slowly and persist for a longer period of time (up to about $12 \mathrm{mo}$ ) following the earthquake; they are thought to be caused by changes in tectonic stress occurring both before and after the earthquake.

The type of earthquake-induced hydrologic response predicted in a numerical analysis depends on the kind of input disturbance applied in the model. For example, models based on direct application of seismic energy will predict mainly the short-term effects. If the seismic waves are strong enough to cause permanent changes in permeability, then some long-term effects may also be predicted. On the other hand, those models that account for both the release of seismic energy and the preceding and consequent stress changes may predict both long- and short-term responses. Similarly, the type of earthquake-induced hydrologic response observed through field measurements would vary, depending on the frequency and duration of measurement. Earthquake-induced hydrologic changes are superimposed on the ambient hydrologic changes; such as diurnal variations due to earth tide, barometric pressure variation, seasonal variations, and long-term changes due to such factors as water loss through wells and mine openings. Because the short-term earthquake-induced changes develop more rapidly than the ambient effects, they can be separated out quite easily. However, because they last only for a short time (matter of hours) following the earthquake, the short-term earthquake-induced changes are best observed through frequent (e.g., minute by minute) sampling. On the other hand, the long-term response develops almost at the same rate as the ambient hydrologic changes; consequently, it is necessary to collect data over several years in order to separate the earthquake-induced long-term response from the ambient response.

The hydrologic response at the Lucky Friday Mine during the field work included the normal seasonal hydrologic variations, diurnal variations, mining-induced water table drawdown, and the earthquakeinduced changes. The data collected are not sufficient to enable the separation of possible earthquakeinduced long-term effects from the ambient response. On the other hand, the data were sampled frequently enough to enable the recognition of several episodes of earthquake-induced short-term effects.

More than 50 seismic events of Richter magnitude 1.0 or larger occurred during the field work, the largest event being of magnitude 3.5. The majority of the events were of magnitude 2.5 or less. Their effects on 
groundwater pressure were observed using piezometers installed in isolated sections of a 360 -m-long inclined borehole, drilled from the 5,700 level station of the mine. The observed effects consist mainly of increase in groundwater pressure, though some decrease was also observed. Most of the observed changes developed rapidly, almost at the same time as the causal seismic event, and dissipated within $24 \mathrm{hr}$, thereafter.

In general, the magnitude of groundwater pressure change increased as the event magnitude increased; for a given event magnitude, the groundwater pressure change decreased as the distance of the observation point from the source location increased. Regression analyses were performed, using both linear and nonlinear models, in an attempt to model the groundwater pressure change as a function of earthquake magnitude and source distance. It was observed that the groundwater pressure change due to events of magnitude 3.0 or larger deviated most from values predicted using the resulting statistical models. The measured values for such events were consistently larger than the predicted values. It is believed that this inability to predict the groundwater response correctly is because the groundwater pressure change associated with small magnitude earthquakes is most likely caused by elastic rock deformations, whereas the contribution of inelastic deformations is likely to increase rapidly as the earthquake magnitude increases. To obtain a statistical model that would be applicable to a wide range of earthquake magnitudes, the database from which such a model would be derived needs to include data from a similar range of earthquakes.

Based on these results, it is suggested that the effect of earthquakes on groundwater flow may be better understood through mechanistic modeling, instead of the statistical modeling approach discussed previously. Such a mechanistic model should provide for a means of relating changes in stress to changes in the hydraulic conductivity and storage capacity of a rock mass and for the analysis of transient fluid flow. The model should also provide for either the direct external input of seismic energy or for the internal generation of seismic motion through intact rock failure or slip on a pre-existing surface. 


\section{INTRODUCTION}

\subsection{BACKGROUND}

Several aspects of nuclear waste management and underground repository design impose more stringent design and performance requirements on a repository than would be called for by established practices for other underground openings, such as mines and oil and gas storage facilities. For example, the time scale ( $\geq 10,000 \mathrm{yr}$ ) mandated for effective waste isolation calls for a broad and in-depth understanding of rock mass behavior and its associated groundwater system over a range of time that may transcend the domain of current underground rock engineering experience. The rock mass at the proposed waste emplacement horizon of Yucca Mountain is understood to be competent, with prominent vertical and subvertical jointing; there are also several small- and large-scale faults within an area of about $100 \mathrm{~km}$ radius around the potential repository site. The rock mass is unsaturated at the repository horizon, with the water table being 200 to $400 \mathrm{~m}$ (656 to $1,312 \mathrm{ft}$ ) below the horizon. In the assessment of the site, those natural phenomena that could adversely affect the achievement of the prescribed performance objectives will need to be considered. A phenomenon that could affect the long-term performance of a repository is ground motion due to earthquakes. One of the concerns is the effect of such earthquakes on the hydrologic regime.

During the development of the site characterization plan for the proposed repository (U.S. Department of Energy, 1988), a report by a U.S. Department of Energy (DOE) staff hydrologist (Szymanski, 1989) suggested that the groundwater level in the Yucca Mountain area had periodically risen well above the proposed repository level. The report attributed the suggested rise and fall of the groundwater table to cyclic stress changes and to deformation related to the seismicity of the region. The possibility of such groundwater level changes would lead to serious questions regarding the suitability of the site. The conclusions of the report were based primarily on the occurrence of the following within the region: (i) near-surface and subsurface carbonate and siliceous fracture fillings, or veins; (ii) breccias cemented by carbonate and silica; and (iii) surficial and surface-parallel deposits of carbonate and silica.

A panel set up by the National Academy of Sciences (NAS), in response to a DOE request, examined both the report and the field evidence, and concluded that the available geologic and geochemical evidence do not support the occurrence of such magnitude of groundwater level changes in the past (National Academy of Sciences/National Research Council, 1992). The NAS panel argued that the geologic and geochemical evidence strongly support a surface-process origin from rainwater for the vein and surface parallel carbonate and carbonate-silica deposits throughout the Yucca Mountain area. The panel suggested that, although the available scientific evidence does not support the occurrence of largescale rise in the water table in the past, the possibility of a significant water table rise occurring in the future should be examined carefully. The panel identified three possible mechanisms that could cause a significant water table rise: (i) an increase in rainfall, (ii) igneous intrusion, and (iii) earthquake. There is still considerable uncertainty regarding the magnitude of hydrologic response that could be generated by each of these mechanisms.

Hydrologic changes associated with earthquakes have been reported in the literature, mainly in terms of observed changes in stream discharge and groundwater levels. Waller (1966) described the effects of the March 27, 1964, Alaska earthquake (Richter magnitude 8.4-8.6) on the hydrology of the Anchorage, Alaska, area. The hydrologic effects of the earthquake were observed through a network of observation wells and stream-gauging stations, which had been in operation for about $15 \mathrm{yr}$ prior to the 
earthquake; therefore, a large amount of pre-earthquake data were available to enable separation of the effects of the earthquake from normal seasonal variations. The observed earthquake effects included increased stream discharge and both decrease and increase in groundwater levels. Some of the changes occurred immediately following the earthquake and lasted for a short time, but others developed more slowly and lasted for up to 6 mo. For example, it was noted that the piezometric levels in the glacio-

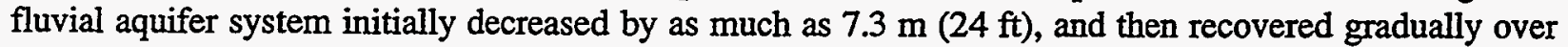

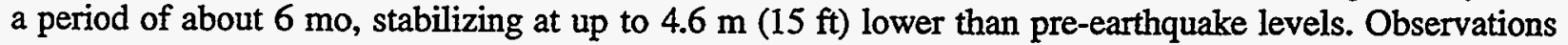
in one well suggest that similar changes may have occurred in the Tertiary bedrock beneath about $122 \mathrm{~m}$ (400 ft) of glacial deposit. The effect of the earthquake was also observed at a well in Ottawa, Canada (Bower and Heaton, 1978). The water level in the well dropped suddenly by about $0.3 \mathrm{~m}(1 \mathrm{ft})$ and then recovered slowly over a period of several days.

The hydrologic effects of the magnitude 7.3 Borah Peak (Idaho) earthquake, which occurred on October 28, 1983, were documented by Wood et al. (1985). The effects include increase in spring and stream discharge, and both increase and decrease in groundwater levels. A piezometric head increase of up to $35 \mathrm{~m}$ (115 ft) was observed in the epicentral area. The earthquake was caused by a normal fault, and the associated hydrologic changes were observed to occur more in the hanging wall area than in the footwall area. Similar to the Alaskan earthquake, some of the effects occurred immediately and lasted for a short time, whereas others lasted much longer. Figure 1-1 shows data collected for a shaft at the Clayton Silver Mine, located in the hanging wall about $24 \mathrm{~km}$ west of the nearest surface faulting associated with the earthquake. The figure shows a rise in water level in the shaft, by about $55 \mathrm{~m}(182 \mathrm{ft})$, despite continuous pumping at about $930 \mathrm{gal} .\left(3.5 \mathrm{~m}^{3}\right)$ per min. The water level declined slowly over a period of about $2 \mathrm{mo}$, after the pumping rate was increased to about 2,000 gal. $\left(7.6 \mathrm{~m}^{3}\right)$ per min. The hydrologic effects of the Borah Peak earthquake have also been examined recently by Muir-Wood and King (1993). They used stream flow changes associated with two major normal fault earthquakes in the western United States (those of Hebgen Lake, magnitude 7.5, in August 1959 and Borah Peak) to examine the relationship between earthquake-induced strains and hydrologic changes.

Rojstaczer and Wolf (1992) studied the hydrologic consequences of the magnitude 7.1 Loma Prieta, California, earthquake, which occurred on October 17, 1989. They reported that groundwater levels in the highland parts of the Pescadero drainage basin dropped by as much as $21 \mathrm{~m}$ within weeks to months following the earthquake, whereas the discharge rate of springs and streams within the basin increased within $15 \mathrm{~min}$ after the earthquake. The increase in discharge dissipated within months.

Three earthquakes occurred on June 28-29, 1992, namely, a magnitude 7.5 earthquake near Landers, California; a magnitude 6.6 event near Big Bear Lake, California; and a magnitude 5.6 event near Little Skull Mountain, Nevada. These earthquakes caused significant water level changes throughout the Yucca Mountain area (O'Brien, 1993). The Landers earthquake caused the water level to fluctuate by as much as $0.9 \mathrm{~m}$ in well USW H-5, which is located on the crest of Yucca Mountain. The Big Bear Lake earthquake caused a water level fluctuation of $0.2 \mathrm{~m}$ in the same well. The Little Skull Mountain earthquake occurred about $23 \mathrm{~km}$ from Yucca Mountain, and caused a maximum water level rise of $0.39 \mathrm{~m}$ in well USW $\mathrm{H}-5$.

The magnitude 6.8 Northridge earthquake of January 17, 1994, which occurred in San Fernando Valley, California, caused a rapid water level increase in wells located in Chino Basin about $75 \mathrm{~km}$ (50 miles) from the epicenter (Thrupp and Wuthrich, 1994). The rise in six wells ranged from 3 to $18 \mathrm{~cm}$ (0.1 to $0.6 \mathrm{ft})$. 


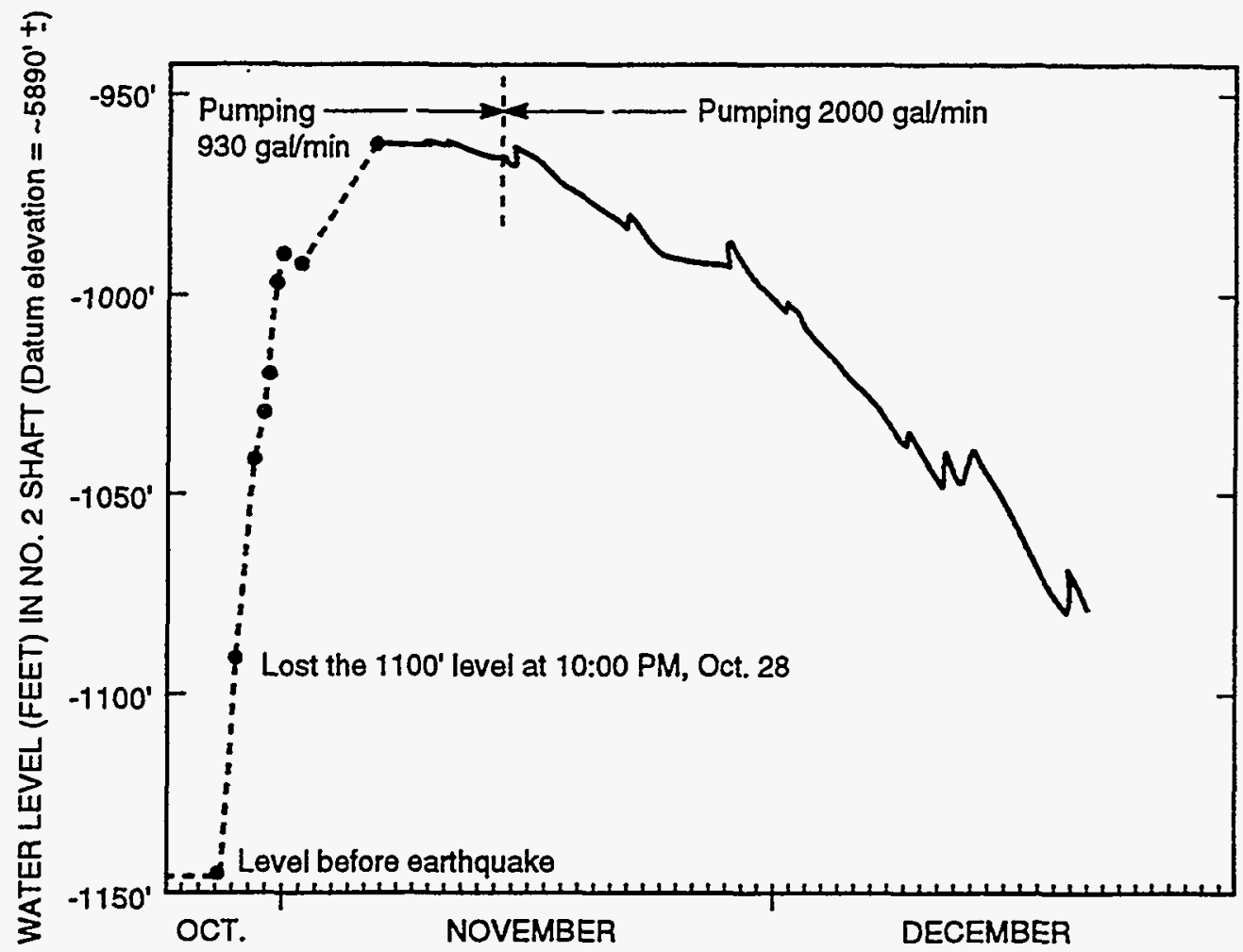

Figure 1-1. Water level changes in a shaft at the Clayton Silver Mine, following the October 1983 Borah Peak earthquake (from Wood et al., 1985)

Raney (1988) provided a summary of the hydrologic effects of selected earthquakes that occurred during 1852-1983 in the Western North American Intermontane Region. The earthquakes occurred at Pleasant Valley, Nevada (Jones, 1915); Cedar Mountain, Nevada (Gianella and Callaghan, 1934); east of Fallon, Nevada (Slemmons, 1956); Dixie Valley, Nevada (Zones, 1957); and Hebgen Lake, Montana (de Costa, 1964). Their hydrologic effects include flooding of mines, increase or decrease of flow in springs and streams, formation of new springs, and drying up of some existing ones.

The effects of earthquakes on groundwater flow may have some implications with respect to the performance of an underground repository. For example, it may affect the distribution of hydraulic gradient and, consequently, the groundwater travel time (GWTT); it may also affect the possibility of water flow toward the waste package. In order to understand such implications, techniques are required for the simulation of both rock mass and groundwater response to earthquakes. A reliable set of field data reflecting the relationship between seismically induced hydrologic changes and the causal earthquakes would contribute to the development of the required simulation techniques. With these factors in mind, a field study was undertaken by the Center for Nuclear Waste Regulatory Analyses (CNWRA) under contract with the Nuclear Regulatory Commission (NRC).

\subsubsection{Mechanisms of Earthquake-Induced Hydrologic Changes}

Earthquake-induced hydrologic changes generally fall into two categories (cf. Rojstaczer and Wolf, 1992): (i) Short-term effects on groundwater levels, which build up and dissipate very fast (within 
a matter of hours or a few days following the earthquake); and (ii) Long-term changes in stream flow and groundwater levels, some of which have been known to persist for 6-12 mo following the earthquake.

The short-term effects can readily be attributed to groundwater response to compressional waves associated with earthquakes (cf. Rojstaczer and Wolf, 1992). For example, the water level oscillations observed in the wells USW H-5 and H-6, that were associated with the Little Skull Mountain earthquake were most likely related to seismically induced cyclic compression of water in rock fractures and pores.

The mechanisms that have been suggested to account for the long-term changes belong to two groups, namely, (i) aquifer compression, and (ii) changes in aquifer/aquitard permeability.

\subsubsection{Aquifer Compression}

The stress changes associated with an earthquake cause changes in water pressure, due to an increase or decrease in the volume of crack or pore space available for water storage in the rock mass. The excess pressure dissipates over a period of time because the water flows into areas of lower hydraulic head. The phenomenon is actually initiated long before the earthquake, by the gradual buildup of crustal stress as a result of viscous motion at depth [cf. Kemeny and Cook (1990); Nur (1974)]. The gradual stress buildup continues until rock strength is overcome at some point, at which time rupture occurs. Following the rupture, stress drops rapidly to a lower value. In extensional regions of the crust, associated with normal faulting, the "stress buildup" causes a decrease in horizontal stress, which in turn causes an increase in crack and pore volumes, and a decrease in water pressure. Following the occurrence of rupture and the consequent "stress drop," the horizontal stress increases rapidly, leading to a rapid increase in water pressure; thereafter, the excess pressure dissipates slowly as the water flows into areas of lower hydraulic head. The stress change accompanying normal fault earthquakes is usually more pronounced in the hanging wall than in the footwall. Therefore, its hydrologic consequences, that is, increase in groundwater pressure and stream discharge, tend to occur more in the hanging wall area (e.g., Wood et al., 1985).

The mechanism for this category of long-term hydrologic effects is similar to the one discussed earlier for the short-term effects. The important difference between them is that the short-term effects are caused by the seismic energy released by fault rupture (or fault slip), whereas the long-term effects under this category are caused by stress changes that occur prior to, and after the release of seismic energy. The importance of this difference relates to the magnitude and time rate of the associated hydrologic effects and to the method and input data required to model the effects numerically.

Muir-Wood and King (1993) applied the concept of aquifer compression to explain the increase in stream discharge associated with the Hebgen Lake and Borah Peak earthquakes. They argued that the hydrologic effect of pure reverse faults (associated with gradual increase in horizontal stress, and a rapid decrease following faulting) should be the opposite of pure normal faults; that is, pure reverse faults should cause a decrease in groundwater pressure and stream discharge. Though there is insufficient empirical data to verify the hydrologic signature of reverse fault earthquakes, the data available for normal faults, and the theoretical understanding of the stress changes associated with normal faulting, offer strong evidence in support of the aquifer compression mechanism for some long-term earthquake-induced hydrologic changes. 


\subsubsection{Change in Aquifer/Aquitard Permeability}

Earthquake-induced rock deformation may cause changes in the permeability of an aquifer or the neighboring aquitard or both, leading to significant changes in discharge rates and, consequently, hydraulic heads. A good example was reported recently by Rojstaczer and Wolf (1992). They examined stream flow and water chemistry data, as well as groundwater level data from utility wells, for the San Lorenzo and Pescadero drainage basins (California), following the 1989 Loma Prieta earthquake. They observed an increase in stream discharge above the normal seasonal changes, along with a decrease in groundwater levels, especially in areas of high elevation. They also observed an increase in calcite saturation index and a decrease in water temperature (for the stream water), which were interpreted to indicate that the additional stream discharge was derived from groundwater from surrounding highlands. Furthermore, they suggested that these changes were most likely caused by an increase in permeability due to seismically induced opening of micro- and macrofractures. The earthquake-induced deformations caused an enhancement of the fracture networks that control groundwater flow in the area. As a result, groundwater flow rates increased initially, causing a surge in stream discharge rates. The increased discharge caused groundwater levels to drop, especially in relatively elevated areas. The excess stream discharge dissipated rapidly because of the decay of the driving hydraulic head.

\subsubsection{Numerical Modeling of Earthquake-Induced Hydrologic Changes}

Three general mechanisms of earthquake-induced hydrologic changes were identified in the foregoing section, namely, (i) dynamic changes in water pressures, due to the dynamic compression/extension of rock caused by the seismic waves; (ii) aquifer compression due to the stress buildup and stress release accompanying earthquakes; and (iii) changes in aquifer/aquitard permeability caused by rock deformation. Because the physical phenomena associated with these mechanisms are very different, the method(s) adopted for modeling earthquake-induced hydrologic changes will depend on which mechanisms are considered important.

\subsubsection{Short-Term Changes Related to Seismic Waves}

The following information is required to model the short-term hydrologic changes, caused by the response of fractured/porous rock to seismic waves:

(i) A description of the seismic signal;

(ii) A description of the constitutive behavior of the rock mass, sufficient to relate changes in rock stress to changes in crack/pore volume and changes in water pressure; and

(iii) A description of the fluid-conductance characteristics of the rock, sufficient to permit modeling of transient fluid flow.

Items (i) and (iii) are likely to be implemented in several currently available geomechanics numerical codes; on the other hand, it would be necessary to develop a formulation of item (ii) and possibly implement it in an available numerical code, in order to provide the analytical capability required to model this problem. 


\subsubsection{Long-Term Changes Due to Aquifer Compression}

This mechanism of earthquake-induced hydrologic changes is difficult to model because the required input information is difficult to obtain. The following information is required as input:

(i) The magnitude and distribution of the stress change. Obtaining this information requires the capability to generate the spatial distribution of stress change, using a model of the stress buildup and fault rupture/slip phenomena. This approach is difficult to accomplish. Therefore, an approximate measure of the stress change is often obtained through the stress-drop parameter, which Kemeny and Cook (1990) described as "the best measure for changes in ground stress following an earthquake."

(ii) The location, geometry, and mechanical behavior of pre-existing rupture surfaces, or a description of the constitutive behavior of intact rock, sufficient to predict rupture initiation and growth, or both.

(iii) A description of the constitutive behavior of the rock mass, sufficient to relate changes in rock stress to changes in crack/pore volume and water pressure.

(iv) A description of the fluid-conductance characteristics of the rock, sufficient to permit modeling of transient fluid flow.

Kemeny and Cook (1990) proposed the following empirical formula for calculating the maximum rise in water table $\left(\Delta z_{w}\right)$ caused by a normal fault earthquake:

$$
\Delta z_{w}=\Delta \sigma\left(1.1 \times 10^{-10}\right) h
$$

where $h$ is the vertical depth of faulting, estimated using the following equation:

$$
h=(\sin \theta)\left[\frac{C M_{0}}{3 \pi \Delta \tau}\right]^{1 / 3}
$$

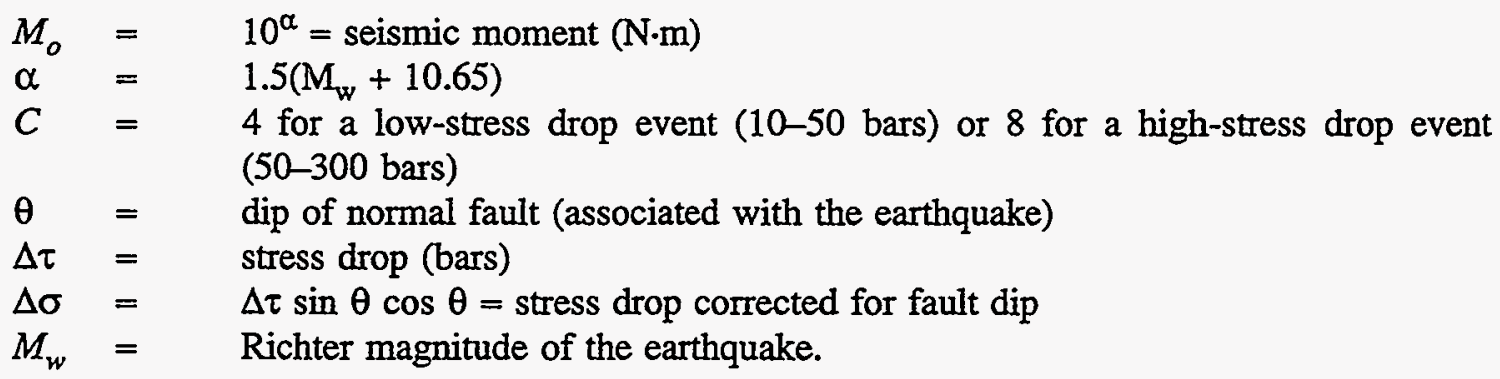

Using this formula, Kemeny and Cook (1990) calculated an average water table rise of $4.5 \mathrm{~m}$ for the Borah Peak earthquake (magnitude 7.3, fault depth of $15 \mathrm{~km}$, and stress drop of $30 \mathrm{bars}$ ), and about $15 \mathrm{~m}$ for the Hebgen Lake earthquake (magnitude 7.5, fault depth of $15 \mathrm{~km}$, and stress drop of 110 bars). In deriving this formula, Kemeny and Cook (1990) made assumptions regarding the volume of rock subjected to co-seismic stress change, the distribution of the stress change within that volume, the pore/fracture compressibility of the rock mass, the rate of flow of the displaced water, and the degree of saturation above the water table. They cautioned, and rightly so, that the water table rise calculated using 
this formula represents an average value over the affected volume of rock; locally, the rise in the water table could be much larger along faults or fracture zones. For example, as was reported earlier, the Borah Peak earthquake caused a piezometric rise of about $35 \mathrm{~m}$ in the epicentral area, as well as a water level rise of about $55 \mathrm{~m}$ in a mine shaft; both of these numbers are very large compared to the average water table rise of $4.5 \mathrm{~m}$ computed using the empirical formula (see Figure 1-1 and Wood et al., 1985).

\subsubsection{Long-Term Changes Due to Change in Rock Mass Permeability}

The permeability of a rock mass may change significantly as a result of rock fracturing and the re-opening or closure of existing fractures under the influence of earthquake-related stress change. Significant changes in the hydrologic regime of a rock mass may occur as a result. This phenomenon is difficult to model, because of the involvement of a suite of complicated processes, including nonlinear deformation of intact rock and rock fractures, the relationship between such deformation and the rock mass permeability, and the transient flow of water through variably saturated rock. The following processes need to be accounted for in developing a numerical model of earthquake-induced long-term hydrologic change related to change in rock mass permeability:

(i) Rock fracturing, which may occur as a result of rock strength being overcome locally by the superimposition of earthquake-related stress change on the existing rock stress;

(ii) Opening and closure of existing fractures and pores, due to changes in compressive stress;

(iii) Shear-induced dilation of rock joints and faults;

(iv) Possible changes in fracture connectivity as a result of any of the above deformations; and

(v) Changes in the water storage capacity and conductivity of the rock, as a result of the above deformations.

Numerical codes are available that incorporate aspects of the processes (ii), (iii), (v), and, to a limited extent, (i). Results presented by Ahola et al. (1993) suggest that the numerical code used in that study may be able to account for the (iv)th process; however, the same code does not have facilities to consider fluid flow through the rock matrix (intact rock), which implies that its application would be limited to situations in which it can be assumed that only pre-existing fractures may contribute to changes in rock mass permeability. Such assumptions may be made for situations in which the intact rock porosity is very small and the possible earthquake-related stress changes are not expected to cause any new fractures.

\subsection{REGULATORY FRAMEWORK}

This field study is designed to develop a better understanding of the potential impact of seismicity on the rise of groundwater table. The result of this field study will be used to provide a basis for development of portions of the License Application Review Plan (LARP) related to Section 5.3, "Assessment of Compliance with the Design Criteria for the Preclosure Features of the Underground Facility"; Section 5.4, "Assessment of Compliance with the Engineered Barrier System (EBS) Performance Assessment"; and Section 3.2.2.11, "Potentially Adverse Conditions: Potential for Unsaturated Zone Saturation." 


\subsection{SCOPE OF INVESTIGATION}

The work described in this report is part of a field investigation conducted in 1991 and 1992 by the CNWRA, under contract with the NRC. The field investigation, conducted at the Lucky Friday Mine in the Coeur d'Alene region of Idaho, included measurements of rock deformation, groundwater pressure, and mining-induced seismic events. The investigation was conducted under the auspices of the Seismic Rock Mechanics Research Project, which was initiated to contribute ideas and data toward an understanding of the effects of repetitive dynamic loading on the performance of an underground repository. The aspect of the field investigation dealing with rock deformation and its relationship with mining-induced seismicity has been presented in an earlier report (Hsiung et al., 1992). This report presents the results of the groundwater pressure monitoring, as well as the observed relationship between groundwater pressure changes and mining-induced seismic events.

Groundwater pressure was monitored through four piezometers installed in four different fracture zones, intersected by an inclined borehole drilled from the 5,700-level station of the mine [i.e., section of the mine generally at a depth of $5,700 \mathrm{ft}(1,737 \mathrm{~m})$ below ground surface]. The four fracture zones were isolated in the borehole using inflatable packers. Unfortunately, one of the packers failed; thus, only three of the piezometers gave usable data. The groundwater pressure data were collected over a period of $24 \mathrm{mo}$. Mining-induced seismicity was monitored through a mine-wide macro-seismic monitoring system installed by the U.S. Bureau of Mines augmented by additional instruments installed by CNWRA. The system includes geophones and velocity gages, which enable seismic parameters such as source location, arrival time, and magnitude to be determined. Seismic data were collected over the 24 -mo period of the field investigation.

The background information presented in Section 1.1 identified two types of earthquake-induced hydrologic changes; namely, (i) the short-term changes, which build up and dissipate rapidly; and (ii) the long-term changes, which build up slowly, lasting up to about $12 \mathrm{mo}$. These changes are superimposed on normal seasonal hydrologic variations, as well as hydrologic changes due to other causes, such as mining-induced water table drawdown. Because the earthquake-induced short-term changes develop rapidly, relative to the diurnal, seasonal, and mining-induced changes, they are easy to observe on a groundwater pressure history record, such as was collected in this study. On the other hand, the earthquake-induced long-term changes develop slowly, almost at the same rate as, or perhaps slower than, the seasonal and mining-induced changes. Therefore, their observation requires that the hydrologic changes due to all other causes be separated from the recorded hydrologic data.

If there were no mining-induced drawdown effects, the water pressure data collected in this study (over a period of $2 \mathrm{yr}$ ) might have been sufficient to estimate the seasonal trend of groundwater pressure, which would have enabled the separation of any earthquake-induced long-term effects that might have occurred (compare, for example, Muir-Wood and King, 1993; Rojstaczer and Wolf, 1992). However, mining, and therefore mining-induced drawdown, occurred during the monitoring period. Because the data collected are insufficient to determine the magnitude and distribution of mining-induced drawdown, it is not possible to isolate any earthquake-induced long-term effects that might have occurred. Therefore, the scope of the investigation is limited to an examination of the groundwater pressure data to identify shortterm effects caused by mining-induced seismicity. 


\subsection{SITE EVALUATION AND SELECTION}

Two important factors governed the selection of a mine site for the study. The first factor was that the mine should be seismically active, with a small recurrence time for seismic events. The second factor was that the rock mass should have been previously characterized, both geologically and mechanically, and that the documents containing such characterization be available. In addition, the rock mass should be jointed, to the extent that its mechanical behavior is governed more by the joints than by the intact rock. These conditions provide the likely occurrence of measurable seismically induced deformations and hydrologic changes within a reasonable time span. An additional essential factor was the mining company's permission for the field study to be conducted at the selected mine.

Among the potential sites located in the United States and Canada, the Lucky Friday Mine satisfied all the governing factors for site selection. This mine is in the Coeur d'Alene region, Mullan, Idaho, and has been characterized geologically. Publications dealing with the geology of the region are readily available (Bennett et al., 1989; White and Winston, 1977). In addition, the mine is among several other mines in the region that had been the subject of previous rock mechanics studies (e.g., Pariseau and Moon, 1987; Whyatt, 1986). A database presently exists on the rock mechanics of the Lucky Friday Mine (Whyatt, 1986; Board and Beus, 1989).

The mine experiences frequent mining-induced seismic activity (Jenkins et al., 1990; Williams and Cuvelier, 1988), related to violent rock fracturing or slip on existing faults and bedding planes. These events can be quite large in magnitude; the largest event recorded there so far is of magnitude 4.0 on the Richter scale. 


\section{SITE DESCRIPTION (LUCKY FRIDAY MINE)}

\section{$2.1 \quad$ SITE GEOLOGY}

The Lucky Friday Mine, Mullan, Idaho, owned and operated by Hecla Mining Company, is one of the mines of the Coeur d'Alene Mining District in Idaho's panhandle region (Board and Beus, 1989; Hauntz, 1982). The mining depth as of 1992 was approximately $1,615 \mathrm{~m}(5,300 \mathrm{ft})$ below the ground surface. The Coeur d'Alene Mining District mines are in metasedimentary rocks of the Belt Supergroup of Precambrian age (Bennet et al., 1989). The Belt Supergroup consists of (i) a thick sequence of quartzites and argillites, referred to as the Missoula Group, which attains a total thickness of up to 2,271 m (7,500 ft); and (ii) the Ravalli Group, an older sequence of quartzites and argillites. The Lucky Friday Mine lies in the Ravalli Group, within the Revett and St. Regis Formations. Rocks belonging to the St. Regis Formation occur on the ground surface at the Lucky Friday Mine site, extending generally to a depth of about $457 \mathrm{~m}(1,500 \mathrm{ft})$. A thinly laminated greenish yellow to green-gray argillite, with carbonate-bearing beds, referred to formally as the Upper St. Regis Formation, occurs closest to the ground surface; it is underlain by the Lower St. Regis Formation, which grades from interbedded argillite and impure quartzite at the top, to thick-bedded pure quartzite at the base. The Revett Formation is a thinbedded vitreous quartzite, yellowish gray to nearly white, with cross stratification. It extends from the base of the St. Regis Formation to a depth of about 2,135 $\mathrm{m}(7,000 \mathrm{ft})$, except in the western area of the mine, where outcrops of the Revett Formation occur on the ground surface. It has well-defined upper, middle, and lower members. The field measurements described in this report, and in the earlier report by Hsiung et al. (1992), were conducted in the Lower Revett Formation.

Both the St. Regis and Revett Formations are folded, with synclinal axis plunging a few degrees eastward. The ore body is a steeply dipping vein (dips about $80^{\circ}$ southeast), referred to as the Lucky Friday vein; the minable length of the ore body is about $457 \mathrm{~m}(1,500 \mathrm{ft})$ along its strike, and it lies primarily within the quarzitic Lower Revett Formation; it is located on the north side of the syncline. The vein is bounded on the north by the North Control Fault and on the south by the South Control Fault; it is also intersected by numerous smaller faults (Figure 2-1). The vein material is primarily a complex of galena, sphalerite, and quartz, yielding metals such as silver, lead, and zinc. The surrounding rock consists of a series of steeply dipping (about $70^{\circ}$ southwest) interbedded quartzites and quarzitic argillites, ranging in thickness from a few centimeters to about $1 \mathrm{~m}$. The pure quartzites tend to be hard and brittle, whereas the argillites are much softer (Board and Beus, 1989). The bedding planes often show evidence of previous shear movement. In addition to the bedding planes and faults, the rock mass is also intersected by numerous joints. Board and Beus (1989) identified two joint sets, with average dips of about $65^{\circ}$ north and $70^{\circ}$ east, respectively, average spacing of about $15 \mathrm{~cm}(6 \mathrm{in}$.), and average persistence of $25-50 \mathrm{~cm}$ (10-20 in.). These discontinuities give the rock mass a blocky appearance.

In situ stress measurements indicate that the maximum horizontal stress is about 1.35 times the minimum horizontal stress; the vertical stress and the minimum horizontal stress are approximately equal in magnitude. The maximum horizontal stress in the vicinity of the Lucky Friday Mine is oriented $\mathrm{N} 45^{\circ} \mathrm{W}$; that is, perpendicular to the strike of the ore body.

The mine is currently using the underhand cut-and-fill mining method, advancing downward generally. Four stopes are used on each level, which advance downward in a series of $3.05-\mathrm{m}$ (10-ft) high cuts. The haulage development for each stope is a spiralling ramp in the footwall of the ore body. Almost all the seismic activities in the mine originate from the footwall; the attitudes of the ore body and the 


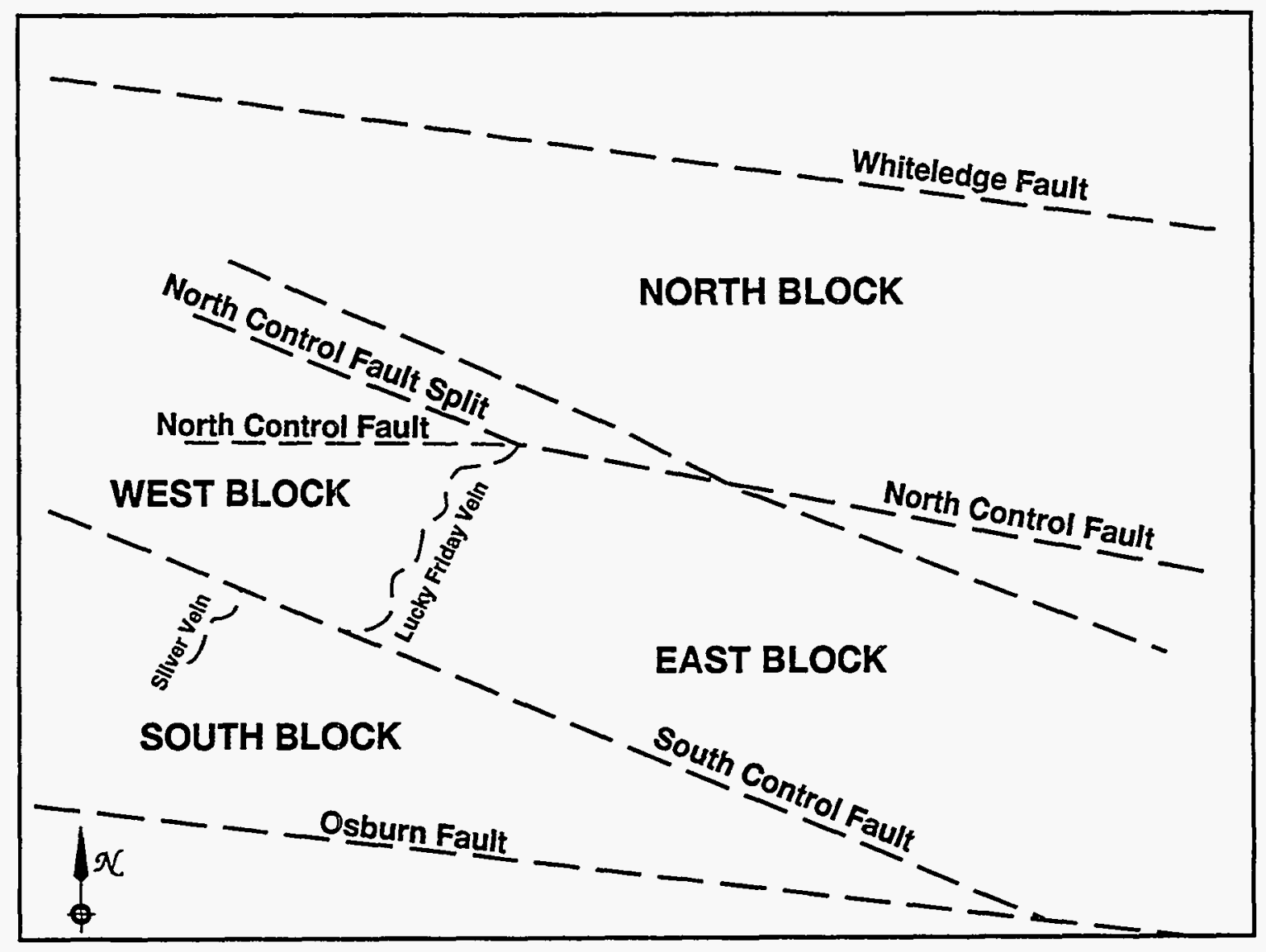

Figure 2-1. Plan view of the Lucky Friday orebody showing fault traces

bedding planes (southeasterly and southwesterly dip directions, respectively) create a situation in which bedding planes dip toward mine openings on the footwall side of the ore body, and away from them on the hanging wall side. Therefore, mining-induced stress change tends to favor bedding slip on the footwall side more than the hanging wall side.

\subsection{MECHANICAL PROPERTIES}

Table 2-1, adopted from Pariseau and Moon (1987), shows average intact rock strength and elastic parameters for three Lucky Friday Mine rock types. Estimates of the rock mass in situ deformation modulus were obtained by Board and Beus (1989), based on the Norwegian Geotechnical Institute (NGD) Q-system and the South African Council for Scientific and Industrial Research (CSIR) rock mass rating (RMR) system, as shown in Figure 2-2. These data are based on rock mass classifications conducted at different mining levels: at depths of $736 \mathrm{~m}(2,414 \mathrm{ft}), 1,238 \mathrm{~m}(4,063 \mathrm{ft}), 1,582 \mathrm{~m}(5,191 \mathrm{ft})$, and $1,815 \mathrm{~m}$ $(5,955 \mathrm{ft})$ below the ground surface. Whyatt (1986) estimated the rock properties for the Coeur d'Alene Mining District based on laboratory test data obtained by previous investigators (Beus and Chan, 1980, 1985; Waddell, 1966; Ageton, 1967a, 1967b; Chan, 1971; Schipke, 1972; Skinner et al., 1974; Miller and Skinner, 1980; and Chan et al., 1972), from more than 300 rock specimens collected from the Revett and St. Regis Formations, at more than ten sites, including the Lucky Friday Mine. Because most of the rock 
Table 2-1. Lucky Friday Mine material property data (from Pariseau and Moon, 1987)

\begin{tabular}{|c|c|c|c|c|c|}
\hline Rock Type & $E(\mathbf{M P a})$ & $v$ & $G(\mathrm{MPa})$ & $C_{o}(\mathrm{MPa})$ & $T_{o}(\mathrm{MPa})$ \\
\hline Vitreous Quartzite & 50,318 & 0.29 & 19,507 & 224.0 & 17.9 \\
\hline Sericitic Quartzite & 10,684 & 0.27 & 4,205 & 78.6 & 10.3 \\
\hline Vein & 11,373 & 0.28 & 4,411 & 104.1 & 10.7 \\
\hline \multicolumn{3}{|c|}{$\begin{array}{l}E=\text { Young's Modulus } \\
\nu=\text { Poisson's Ratio } \\
G=\text { Shear Modulus }\end{array}$} & \multicolumn{3}{|c|}{$\begin{array}{l}C_{o}=\text { Unconfined Compressive Strength } \\
T_{o}=\text { Tensile Strength }\end{array}$} \\
\hline
\end{tabular}

testing programs were conducted as part of in situ stress measurement programs, the rock specimens were collected from sites considered suitable for stress measurement, such as sites with thick beds, and relatively competent rock. The average rock properties by geologic formation for the Coeur d'Alene Mining District, based on these data, are given in Table 2-2.

The data in Table 2-2 suggest a difference in mechanical properties between the Revett and St. Regis Formations. However, a statistical analysis of variance with a 0.05 level of significance by Whyatt (1986), which assigned equal weight to each site, showed no significant difference in any of the four mechanical properties that would be attributed to differences between the two formations. Whyatt (1986) concluded that the mechanical property variations that occur within each formation are more than those between the formations.

Rock core specimens were collected as a part of the field studies described in this report and in Hsiung et al. (1993). Laboratory testing of some of the specimens was conducted to obtain location specific data on the intact rock strength and elastic parameters. The results of the tests are presented in Appendix A.

Table 2-2. Average rock properties by geologic formation (from Whyatt, 1986)

\begin{tabular}{||l|c|c|c||}
\hline \multicolumn{1}{|c|}{ Property } & Overall & Revett & St. Regis \\
\hline \hline Uniaxial Compressive Strength (MPa) & 171.5 & 174 & 169 \\
\hline Indirect Tensile Strength (MPa) & 17 & 16 & 18 \\
\hline Elastic Modulus (MPa) & 54,468 & 52,399 & 56,536 \\
\hline Poisson's Ratio & 0.23 & 0.25 & 0.21 \\
\hline
\end{tabular}




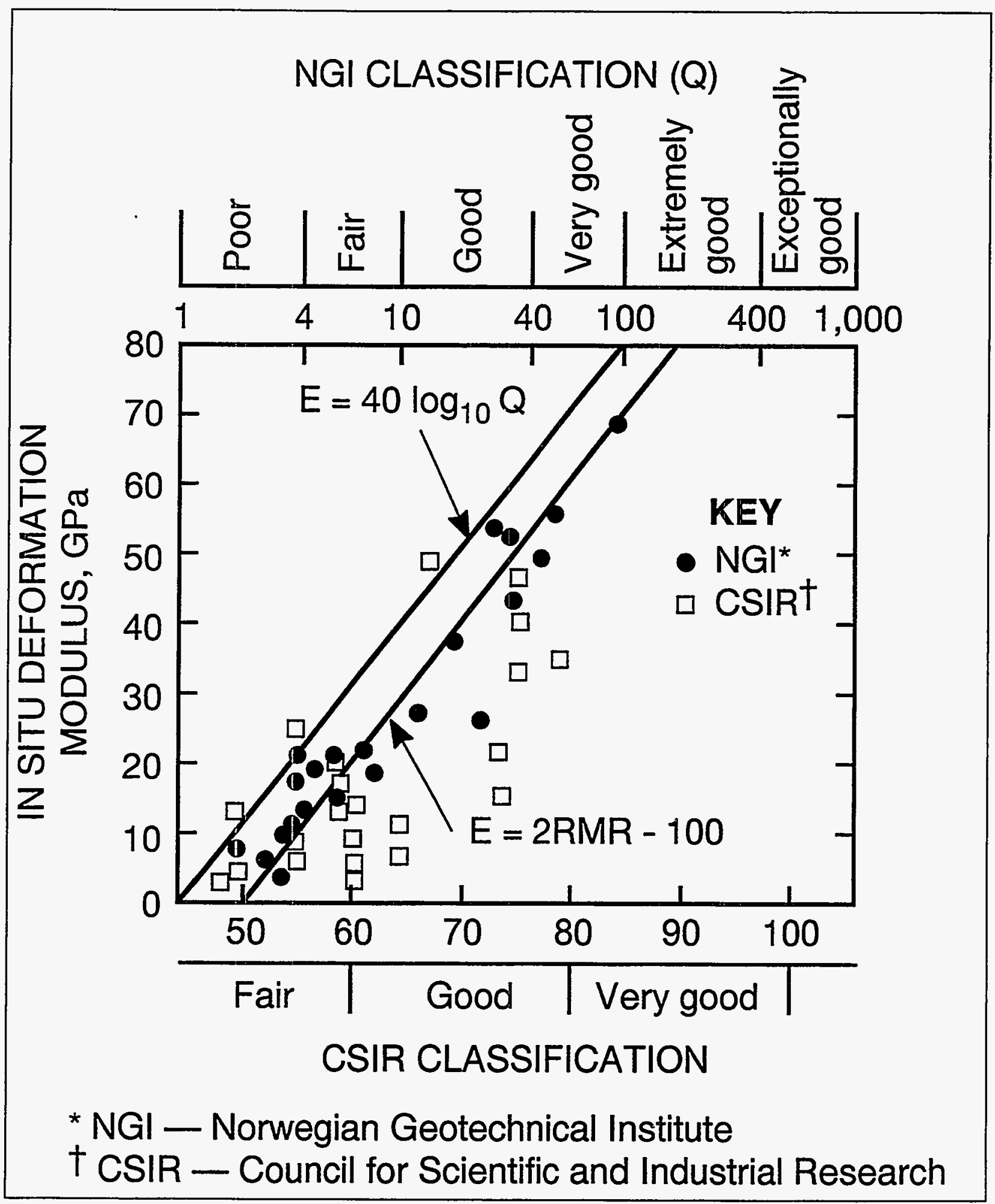

Figure 2-2. Estimation of in situ modulus of deformation from Norwegian Geotechnical Institute (NGI) and Council for Scientific and Industrial Research (CSIR) classification methods (from Board and Beus, 1989) 


\section{SEISMIC MONITORING}

Seismic monitoring was conducted using an existing macroseismic monitoring system set up in the mine by the U.S. Bureau of Mines (USBM), Spokane, Washington, augmented by additional instruments installed by the CNWRA for the field studies.

\subsection{MINE-WIDE SEISMIC INSTRUMENTATION}

The mine-wide seismic monitoring system consists of two systems, one set up by the mining company to monitor microseismic events, and the other set up by the USBM to monitor macroseismic events. The microseismic monitoring system uses an automatic multichannel data acquisition system, connected to a network of transducers, designed to detect acoustic emissions having frequencies of 10 to $5,000 \mathrm{~Hz}$ (Jenkins et al., 1990). The system provides useful information regarding the evolution of active zones in the rock mass. However, many of the events detected by this system are of low magnitude (less than 0.5 on the Richter scale).

The decision was made early in the project to concentrate on events of larger magnitude (more than about 0.5 on the Richter scale), because it was believed that such events are more likely to be associated with measurable mechanical deformation and hydrologic changes. Therefore, the microseismic system was not utilized. Instead, the USBM macroseismic monitoring system (Sprenke and Hammond, 1988), which is targeted on events of Richter magnitude 0.5 or more, was used. The system uses a multichannel data acquisition system connected to a network of geophones and velocity gages, placed at different locations and depths in the mine.

\subsection{ADDITIONAL SEISMIC INSTRUMENTATION}

Two additional triaxial velocity gages were installed by the CNWRA at the 5,210 level. The triaxial gages were installed at the two mechanical deformation monitoring sites, LFM95-C1 and LFM95C2; their installation and calibration have been described in an earlier report (Hsiung et al., 1992). In addition, a hydrophone was installed in Zone 1 of the groundwater pressure monitoring borehole (a description of the borehole is given in Figure 42); however, because of excessive noise in the hydrophone output, the data could not be used as seismic information. The data collected with the velocity gages were integrated with the data collected through the USBM network to determine seismic events parameters, such as source location, arrival time, and magnitude. A schematic illustration of the seismic data acquisition system used for the field work is given in Figure 3-1.

\subsection{SEISMIC DATA}

Numerous mining-induced seismic events were recorded during the field study period. There were more than 50 events of Richter magnitude 1.0 or larger. The largest was a magnitude 3.5 event, which occurred on September 19, 1991. Scatter plots of the event magnitudes versus time are given in Figure 3-2 and 3-3. These plots were developed simply to show when the different events occurred. They are not intended to suggest any relationship between the event magnitudes and time. Mining-induced seismicity is controlled by the progress of mining, whether or not the spatial distribution of mine openings at a given time causes the kind of stress redistribution necessary to induce seismic events, and whether special measures are adopted at a given time by the mine authorities to control stress release. For example, there were more events in 1991 than in 1992, because more mining occurred in 1991. 


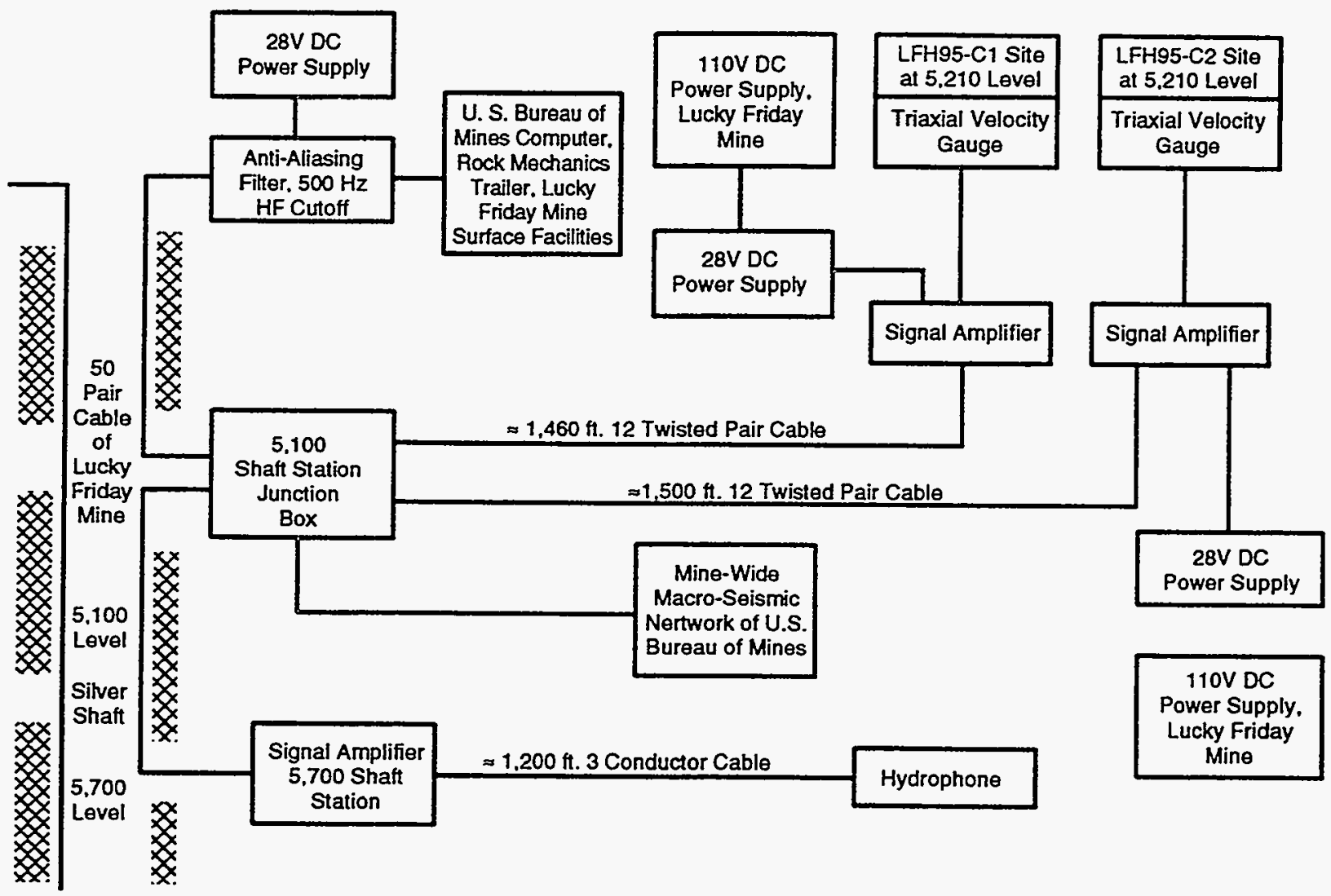

Figure 3-1. Schematic diagram of seismic data acquisition system

\subsubsection{Determination of the Source Locations for the Macroseismic Events}

The source locations of the various events were estimated using a trial-and-error procedure. The basic input data for the procedure are the first arrival time for a seismic signal and the geophone or velocity gage locations at which it was recorded. The procedure begins with an assumed source location. Then the first arrival time of the seismic wave is calculated for the various geophone/velocity gage locations, using the shear wave velocity and distance of the various travel paths (each travel path connects a geophone or velocity gage location to the assumed source location). The average arrival time error (total error divided by number of instrument locations) is compared with a predetermined tolerance, and the process is repeated until a source location is found that gives an average error smaller than the tolerance. The potential error caused by the tolerance alone (for the value of tolerance used in this project) is about $7.6 \mathrm{~m}$ (25 ft). Additional errors may also occur, due to the following causes: (i) The values of shear wave velocity assigned to the various travel paths may be incorrect. The shear wave velocity along each path depends on the elastic stiffness of the rock mass in the direction of the path, which is influenced by the rock discontinuities intersected by the path. The USBM conducted a calibration study at the mine, by monitoring the arrival times for blast waves generated at known locations. However, because the values of wave velocity obtained from this study apply only to the travel paths for which they were calculated, it is not likely that their use would reduce errors due to rock mass inhomogeneity, by an amount commensurate with the amount of effort required to incorporate them in the trial-and-error procedure. 


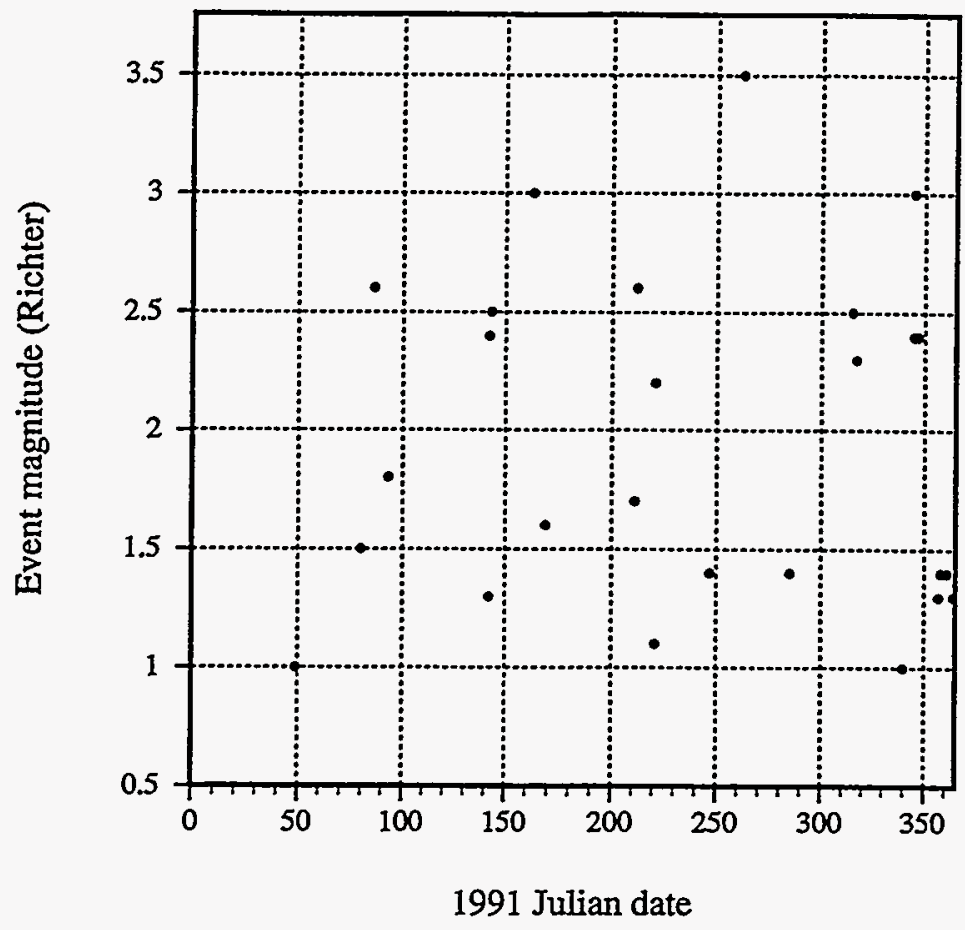

Figure 3-2. Observed seismic events during 1991

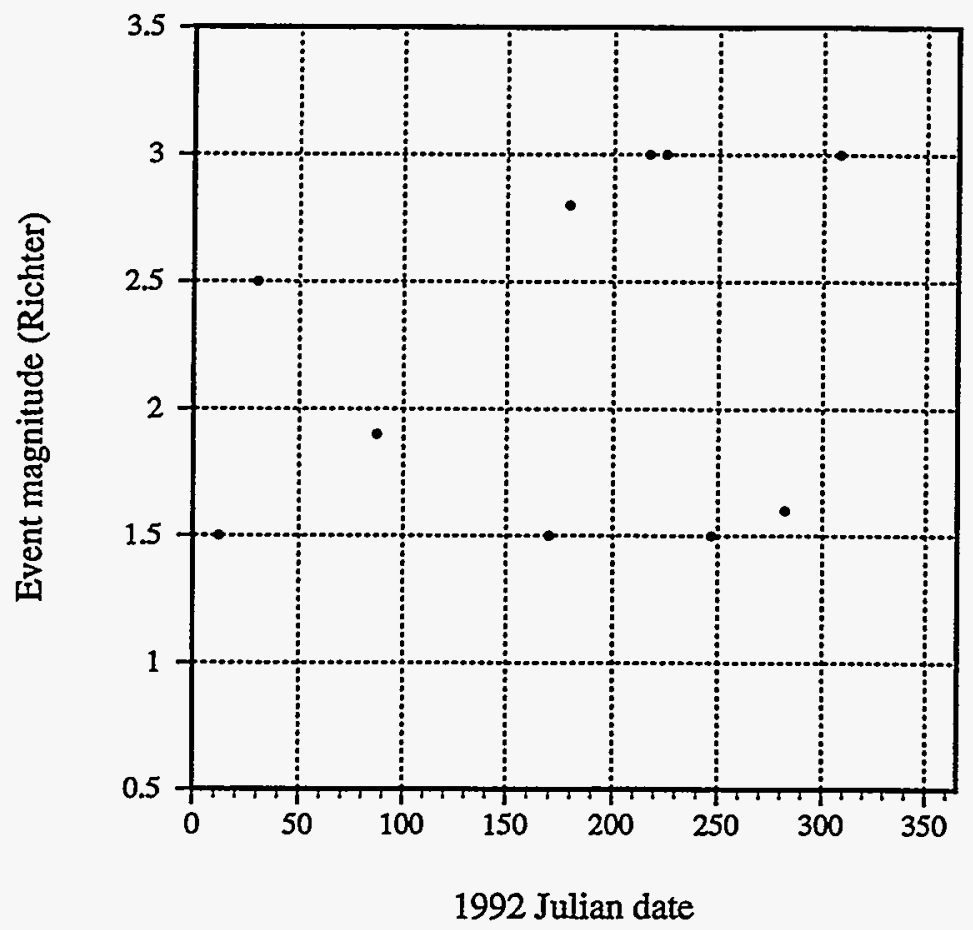

Figure 3-3. Observed seismic events during 1992 
Therefore, a constant value of shear wave velocity was applied to the procedure in this project. (ii) The source mechanism of a seismic event (rock fracturing or slip on pre-existing fracture) usually occurs over an area. The error caused by treating the source location as a point instead of an area is likely to be less significant as the distance of the recording instrument from the source location increases. In this study, it is very likely that the source and instrument locations are so close that the area over which the source mechanism occurred should have been considered. But no information was available that would have enabled consideration of the area of the source mechanisms.

Table 3-1 lists the seismic events that caused measurable groundwater pressure changes at the piezometer locations (described in Chapter 4), along with the source location coordinates calculated for such events using the above procedure. The coordinates are given in terms of a rectangular East-North-Depth system: East is positive eastward with origin at $6,096 \mathrm{~m}(20,000 \mathrm{ft})$ from the origin of the coordinate system used at the mine; North is positive northward with origin at $6,096 \mathrm{~m}$ from the mine origin; while Depth is positive downward with origin at sea level, which is at a depth of $1,025 \mathrm{~m}$ $(3,363 \mathrm{ft})$ below the ground surface at the mine. Additional seismic data obtained during the field work, in connection with the mechanical response monitoring, have been given in previous reports (Hsiung et al., 1992; Hsiung and Chowdhury, 1991).

\subsubsection{Determination of Peak Particle Velocity}

Values of the peak particle velocity associated with some of the events were determined for the two mechanical deformation monitoring sites using data recorded by the CNWRA velocity gages. Details of these data are given in an earlier report (Hsiung et al., 1992). Because the groundwater pressure monitoring points were located deep in a borehole (as described in Chapter 4) away from the existing mine openings, they were not accessible for locating additional instruments such as velocity gages. Therefore, data were not collected to enable the determination of peak particle velocities at locations close to the piezometers. 
Table 3-1. Seismic events that produced measurable changes in groundwater pressure

\begin{tabular}{|c|c|c|c|c|c|}
\hline \multicolumn{3}{|c|}{ Seismic Events } & \multicolumn{3}{|c|}{ Event Source Coordinates (m) } \\
\hline Hour & Date & Magnitude & East $^{1}$ & North $^{2}$ & Depth $^{3}$ \\
\hline 0458 & $03 / 27 / 91$ & 2.6 & 68.58 & -22.86 & -586.7 \\
\hline 2124 & $05 / 22 / 91$ & 2.4 & 60.96 & 51.82 & -597.4 \\
\hline 0036 & $05 / 23 / 91$ & 2.5 & 82.3 & 51.82 & -597.4 \\
\hline 2203 & $06 / 12 / 91$ & 3.0 & -33.53 & 15.24 & -487.7 \\
\hline 2203 & $07 / 30 / 91$ & 1.7 & 21.64 & -19.2 & -567 \\
\hline 1204 & $07 / 31 / 91$ & 2.6 & 111.6 & 6.71 & -717.2 \\
\hline 1337 & $08 / 09 / 91$ & 2.2 & 128.0 & 25.91 & -579.1 \\
\hline 0920 & $09 / 19 / 91$ & 3.5 & 365.8 & 182.9 & -510.5 \\
\hline 0037 & $10 / 12 / 91$ & 1.4 & 38.1 & 60.96 & -579 \\
\hline 1337 & $12 / 11 / 91$ & 3.0 & -51.82 & -57.91 & -502.9 \\
\hline 1402 & $12 / 11 / 91$ & 2.4 & 38.1 & -30.48 & -480 \\
\hline 1336 & $12 / 13 / 91$ & 2.4 & 259 & 236 & -579 \\
\hline 1045 & $06 / 27 / 92$ & 2.8 & 335.3 & 106.7 & -571.5 \\
\hline 0226 & $08 / 04 / 92$ & 3.0 & 183 & 53.3 & -625 \\
\hline 0130 & 08/12/92 & 3.0 & -36.58 & -4.57 & -566.9 \\
\hline 2037 & $09 / 03 / 92$ & 1.5 & 75.3 & -98.8 & -600 \\
\hline 0332 & $10 / 08 / 92$ & 1.6 & 297 & 206 & -594 \\
\hline 2121 & $11 / 03 / 92$ & 3.0 & 328 & 274 & -594 \\
\hline \multicolumn{6}{|c|}{${ }^{1}$ East is positive eastward, with origin at $6,096 \mathrm{~m}$ from mine origin } \\
\hline \multicolumn{6}{|c|}{${ }^{2}$ North is positive northward, with origin at $6,096 \mathrm{~m}$ from mine origin } \\
\hline${ }^{3}$ Depth & oitind & ath & 1 & & \\
\hline
\end{tabular}




\section{GROUNDWATER PRESSURE MONITORING}

\subsection{INSTRUMENTATION AND DATA ACQUISITION}

The intact rock of the Lower Revett Formation has very low permeability. On the other hand, several structure-controlled high-permeability zones occur, such as the Osburn and Whiteledge faults, the ore vein, and associated fractures (see Figure 2-1). Therefore, the groundwater pressure monitoring program required the installation of instruments within the high-permeability structures. In addition, the groundwater level at the Lucky Friday Mine lies above the current mining depth, and significant drawdown of the water table occurs as a result of mining. Therefore, it was necessary to locate the instruments below the current mining level to ensure that they remain in the saturated zone during the period of the field studies.

Within the Silver Shaft (main access shaft for the mine), the 5,700 level station, which was

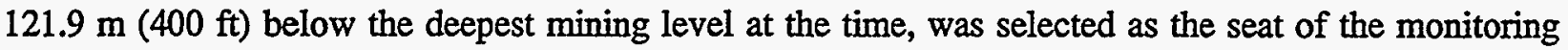
program, with the intention of locating instruments in permeable zones below the station. An NQ size ( $7.6 \mathrm{~cm}$ diameter) borehole was drilled from the station, plunging $20^{\circ}$ in $\mathrm{S} 20^{\circ} \mathrm{E}$ direction. The borehole was intended to intersect the ore vein and South Control fault. It was drilled to a length of about $360 \mathrm{~m}$ $(1,180 \mathrm{ft})$. A borehole survey conducted at the completion of drilling indicated a slight deviation of the borehole from the projected orientation. The bottom of the borehole was about $8.95 \mathrm{~m}(29 \mathrm{ft})$ above and $34 \mathrm{~m}(111 \mathrm{ft})$ to the right (looking at the bottom of the borehole from the collar) of its projected location. All the permeable zones of interest were intersected within $310 \mathrm{~m}(1,017 \mathrm{ft})$ length of the borehole. A rock-quality log of the borehole is given in Appendix B.

It was determined through core logging that five fracture zones (three associated with faults and two with mineral vein) were intersected by the borehole between $183 \mathrm{~m}(600 \mathrm{ft})$ and $360 \mathrm{~m}(1,180 \mathrm{ft})$ along its length. The structures were located at a distance of about $207 \mathrm{~m}(680 \mathrm{ft}), 242 \mathrm{~m}(795 \mathrm{ft}), 269 \mathrm{~m}$ $(883 \mathrm{ft}), 288 \mathrm{~m}(945 \mathrm{ft})$, and $307 \mathrm{~m}(1,006 \mathrm{ft})$ along the borehole, from its collar. Four of the structures were selected for groundwater pressure monitoring. The fracture zone at $269 \mathrm{~m}(883 \mathrm{ft}$ ) was considered minor; therefore, it was not selected.

The selected fracture zones were packed off using inflatable straddle packers (Figure 4-1). The straddle-packer sections were separated by pipe, and stiff pipe sections were used to push the packers into position, using the feed of a diamond drill. The packers were inflated with water pressure through inflation lines. The inflation pressure was set at $2.76 \mathrm{MPa}(400 \mathrm{psi})$, to cause the packers to expand to the borehole size, provide for resistance against groundwater pressure, as well as hold the packers in place. The straddle packers were placed in competent rock zones, based on the core logs, so that they would be seated firmly against the borehole wall.

A vibrating wire pressure transducer (piezometer) was installed between each of the straddle-packer pairs to measure water pressure. Figure 42 shows the locations of the packers and the permeable zones isolated by each packer pair. The structural feature associated with each permeable zone is also identified in the figure. As the figure shows, the deepest zone, referred to as Zone 1, contains the Associated Fractures, a fracture zone parallel to the South Control Fault; the next zone, Zone 2, contains the South Control Fault; the next two zones, Zones 3 and 4, contain the Main Vein and the Footwall Vein, respectively. The inflation line of the packer system for Zone 4 was ruptured when the packers were being inflated. Consequently, Zone 4 was not properly sealed, and water pressure measurements obtained from 


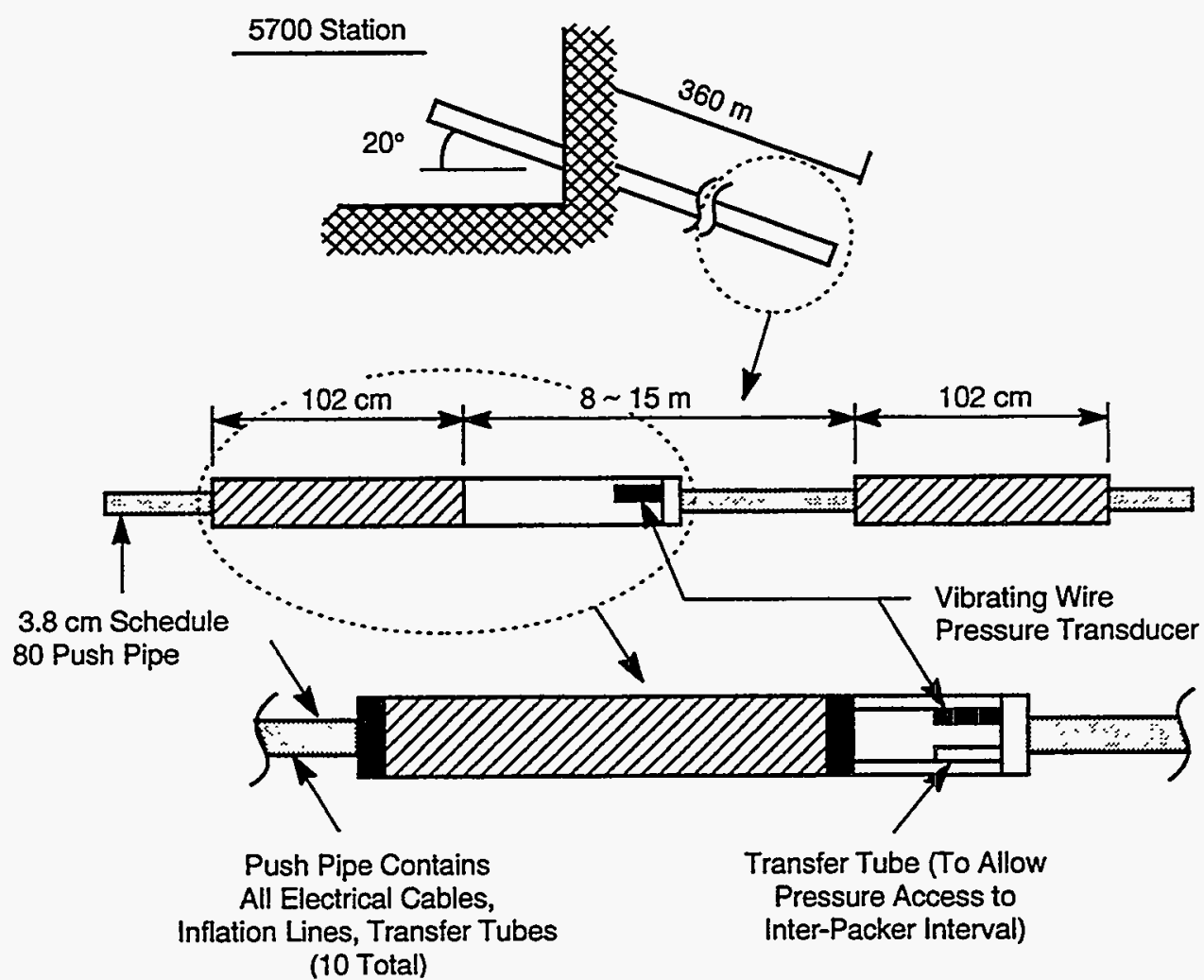

Figure 4-1. Schematic drawing of straddle packer pair with piezometer enclosure

this zone proved to be incorrect. The piezometers for Zones 1,2 , and 3 were installed at borehole distances of $294.4 \mathrm{~m}(966 \mathrm{ft}), 279.5 \mathrm{~m}(917 \mathrm{ft})$, and $221.9 \mathrm{~m}(728 \mathrm{ft})$, respectively, from the collar. The piezometer locations are summarized in Table 4-1, in terms of the East-North-Depth coordinate system, which was explained in Section 3.3.

Table 4-1. Coordinates of piezometer locations

\begin{tabular}{||l|c|c|c|c||}
\hline \multicolumn{1}{|c|}{ Zone } & $\begin{array}{c}\text { Borehole } \\
\text { Distance (m) }\end{array}$ & East (m) & North (m) & $\begin{array}{c}\text { Depth below } \\
\text { sea level (m) }\end{array}$ \\
\hline \hline Borehole collar & 0.0 & -46.0 & 143.3 & 710 \\
\hline Zone 1 Piezometer & 294.4 & 5.49 & -128.6 & 811 \\
\hline Zone 2 Piezometer & 279.5 & 2.74 & -114.9 & 806 \\
\hline Zone 3 Piezometer & 221.9 & -7.32 & -61.6 & 786 \\
\hline
\end{tabular}




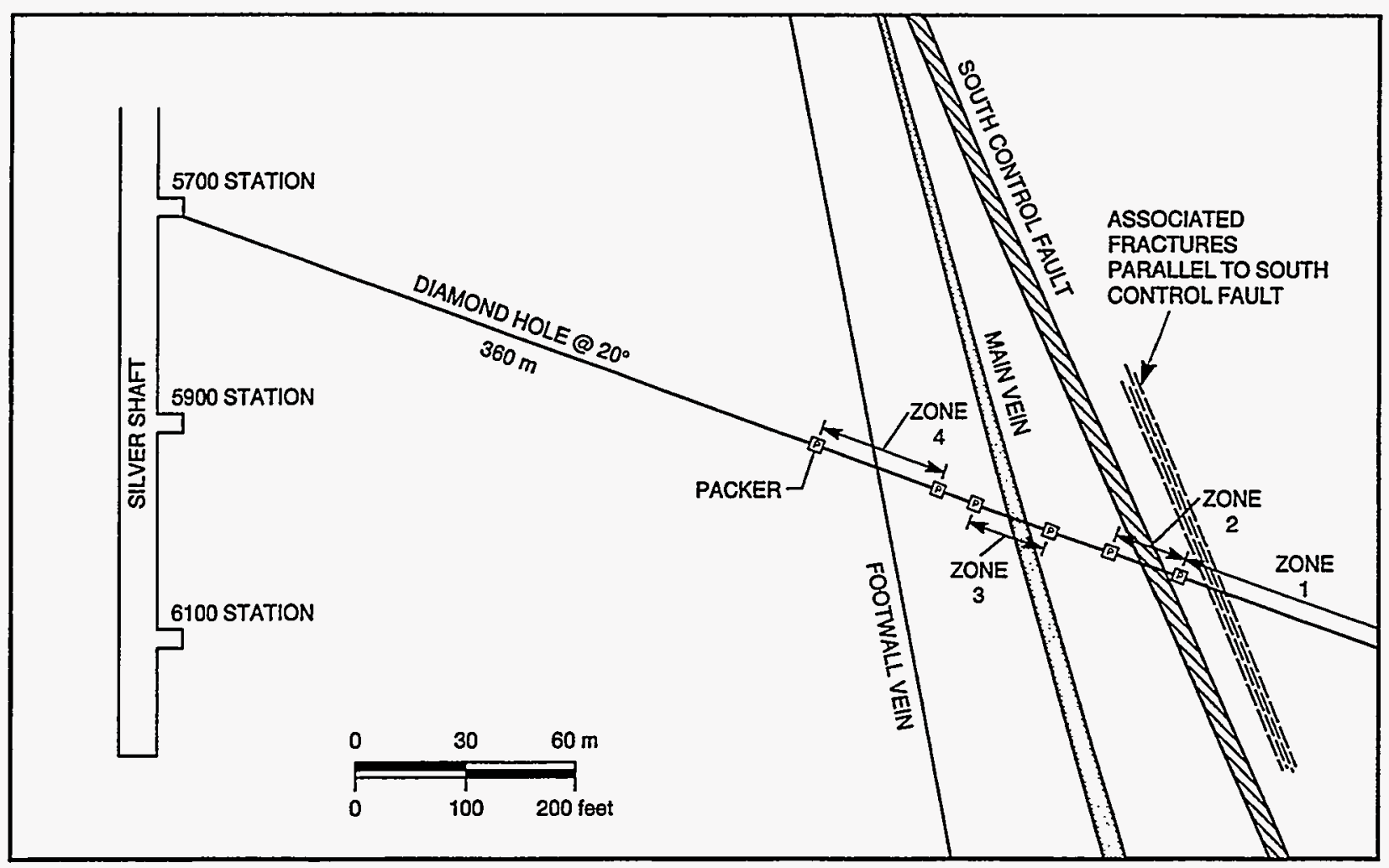

Figure 4-2. Zones packed off for water pressure measurement along the borehole drilled from Lucky Friday Silver Shaft at a depth of $1,737 \mathrm{~m}$ below ground surface

The piezometer data were collected through a data acquisition system that consisted of two underground dataloggers and a surface personal computer. A schematic diagram of the data acquisition system used for the field studies (including instruments used for the mechanical response monitoring project) is given in Figure 4-3. A 32-channel datalogger with power supply was located at the LFM95-C1 mechanical response site. The second datalogger was placed at the 5,700-level station of the Silver Shaft. The four piezometers were connected through a multiplexer to the datalogger at the 5,700-level station. The two dataloggers were networked via a coaxial cable. All instruments communicated with the surface computer via the datalogger at the 5,700 level.

Groundwater pressure measurements were made at $2.25-\mathrm{hr}$ intervals initially; the interval was later reduced to $1 \mathrm{~min}$, after it was determined that the seismic-induced changes lasted for very short durations (of the order of hours to a few days). The data collected were temporarily stored in the datalogger, to be retrieved via a telephone line once a day from the CNWRA, in San Antonio, TX.

Access tubes for additional groundwater pressure measurements were also installed at the piezometer locations. An initial water pressure measurement was taken as soon as it was determined that the packers were properly seated. The initial measurement gave water pressure values of $2.61 \mathrm{MPa}$ (378 psi) for Zone 1, 2.50 MPa (363 psi) for Zone 2, $2.15 \mathrm{MPa}$ (312 psi) for Zone 3, and $0.58 \mathrm{MPa}$ (84.5 psi) for Zone 4. These values compared well with those calculated using data from the access tubes, except for Zone 4 . The relatively small value measured for Zone 4 was because of the leakage of the packer pair for that zone, as was mentioned earlier. 


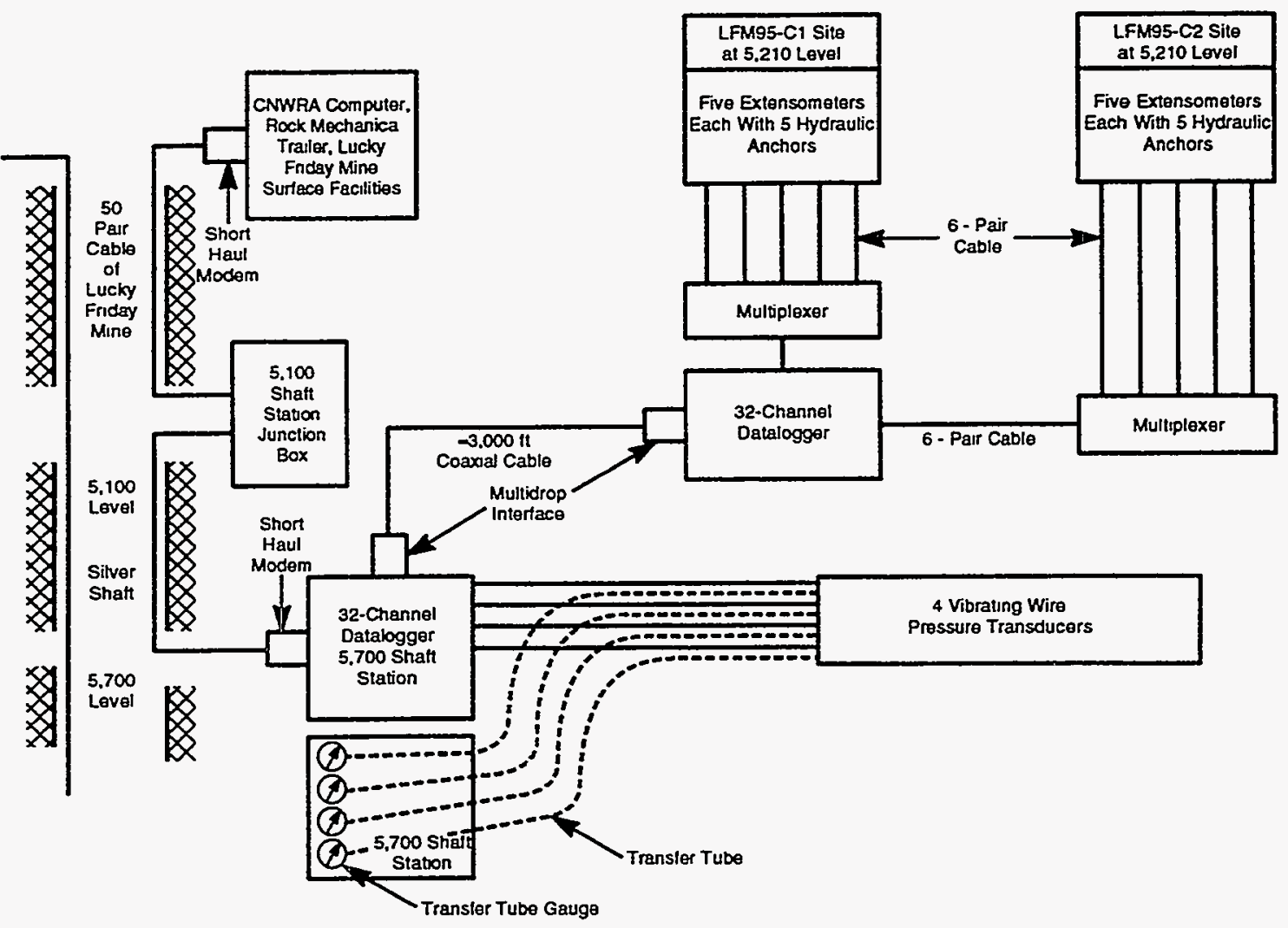

Figure 4-3. Schematic diagram of piezometer data acquisition system

Based on these measurements and the elevation data given in Table 4-1, the initial groundwater heads at the piezometer locations were 546,551 , and $567 \mathrm{~m}$ below sea level, for Zones 1,2 , and 3, respectively, corresponding to depths of $1,571,1,576$, and $1,592 \mathrm{~m}$ below ground surface. Therefore, there was an initial water table drawdown toward the mine.

\subsection{CALIBRATION OF VIBRATING-WIRE PIEZOMETER}

Four Geokon Model 4,500H vibrating-wire transducers were calibrated using a National Institute of Standards and Technology-Traceable Ashcraft Dead Weight Tester. A Geokon GK-401 readout box was used to provide the excitation to vibrate the wire in the piezometer and readout display. The displaced value is in the unit of $f^{2} \times 10^{-3}$ where $f$ is frequency. Each piezometer was calibrated individually, with the pressure being increased from 0 to $3.45 \mathrm{MPa}(500 \mathrm{psi})$ at a $0.69-\mathrm{MPa}(100$-psi) interval and then decreased in similar fashion to 0 . The cycle was repeated twice for each piezometer.

Calibration data were recorded and entered into a Lotus spreadsheet. The changes for the piezometer readings with respect to the initial reading for each piezometer were calculated and listed under the column "Norm" in Table 4-2. A linear-regression analysis was performed for the applied pressure and normalized piezometer readout. The regression results for all four piezometers indicated that they all behaved linearly (with $R^{2}$ value practically equal to one) to pressure changes in the range of interest, that is from 0 to $3.45 \mathrm{MPa}(500 \mathrm{psi})$. The estimated $y$-intercepts are small and negligible. Table $4-2$ presents 
Table 4-2. Transducer serial no. 12785 reading chart

\begin{tabular}{|c|c|c|}
\hline & \multicolumn{2}{|c|}{ Piezometer } \\
\hline Applied Pressure & Readings & Norm \\
\hline 0 & $\begin{array}{l}9,468 \\
\end{array}$ & $\overline{0}$ \\
\hline 100 & 8,669 & 799 \\
\hline 200 & 7,835 & 1,633 \\
\hline 300 & 7,013 & 2,455 \\
\hline 400 & 6,189 & 3,279 \\
\hline 500 & 5,336 & 4,132 \\
\hline 400 & 6,174 & 3,294 \\
\hline 300 & 7,000 & 2,468 \\
\hline 200 & 7,820 & 1,648 \\
\hline 100 & 8,635 & 833 \\
\hline 0 & 9,437 & 31 \\
\hline 100 & 8,637 & 831 \\
\hline 200 & 7,823 & 1,645 \\
\hline 300 & 7,002 & 2,466 \\
\hline 400 & 6,177 & 3,291 \\
\hline 500 & 5,337 & 4,131 \\
\hline 400 & 6,175 & 3,293 \\
\hline 300 & 6,999 & 2,469 \\
\hline 200 & 7,820 & 1,648 \\
\hline 100 & 8,636 & 832 \\
\hline 0 & 9,439 & 29 \\
\hline \multicolumn{3}{|c|}{ Regression Output: } \\
\hline Constant & & -0.79433 \\
\hline Std Err of Y Est & & 1.635372 \\
\hline $\mathrm{R}^{2}$ & & 0.9999 \\
\hline No. of observations & & 21.0 \\
\hline Degrees of freedom & & 19.0 \\
\hline X Coefficient(s) & & 0.121743 \\
\hline Std Err of Coef & & 0.000279 \\
\hline
\end{tabular}

regression results for Piezometer Serial No. 12785. The regression results are in close agreement with manufacturer-provided results. The calibration factors ( $X$ coefficient as shown in Table 42) for all piezometers and those provided by the manufacturer are compared in Table 4-3.

The calibration factors were used to convert piezometer readings to pressure head values, using the following equation 
Table 4-3. Comparison of calibration factors used for the four vibrating wire piezometers used in the study

\begin{tabular}{|c|c|c|c|}
\hline \multicolumn{4}{|c|}{ Calibration Factors $^{*}$} \\
\hline Piezometer No. & Regression Results & Manufacturer Supplied & Difference (\%) \\
\hline \hline 12783 & 0.12543 & 0.12564 & 0.17 \\
12784 & 0.12317 & 0.12331 & 0.11 \\
12785 & 0.12174 & 0.12212 & 0.31 \\
12786 & 0.12795 & 0.12779 & 0.13 \\
\hline *Unit for the calibration factors is psi/digit & \\
\hline
\end{tabular}

$$
h=\alpha A\left(f_{o}-1,000 f\right)
$$

where $h$ is pressure head in meter, $\alpha=0.70104 \mathrm{~m} / \mathrm{psi}, f$ is the piezometer reading, and the values of $A$ and $f_{\mathrm{o}}$ are given in Table 4-4.

\subsection{GROUNDWATER PRESSURE DATA}

A summary of the groundwater pressure history for the three monitored zones during the 24-mo period of the field studies is presented in Figures 4-4 to 49. These data are presented in terms of hydraulic head relative to the borehole collar (which was at a depth of about $710 \mathrm{~m}$ below sea level, as shown in Table 4-1). Because of mining-induced drawdown, the hydraulic head in Zone 3 remained lower than in Zone 2, and the latter was lower than in Zone 1, during the monitoring period.

It is also believed that the general decrease in hydraulic head that occurred during the period of the field study was caused by mine drainage. A general decrease in head of up to $6 \mathrm{~m}$ occurred in 1991; on the other hand, only about a $2-\mathrm{m}$ decrease occurred in 1992, except in Zone 1 , where the hydraulic head declined by about $5 \mathrm{~m}$ between January and December.

Table 4-4. Values of initial reading and calibration factors of the piezometers

\begin{tabular}{|c|c|c|}
\hline Piezometer & Initial Reading $f_{o}$ & Calibration Factor $A$ \\
\hline \hline Zone 1 Piezometer & 9490.5 & 0.125431 \\
\hline Zone 2 Piezometer & 8457.3 & 0.123166 \\
\hline Zone 3 Piezometer & 9448.0 & 0.121743 \\
\hline Zone 4 Piezometer & 9830.3 & 0.127946 \\
\hline
\end{tabular}


Event magnitude (Richter)

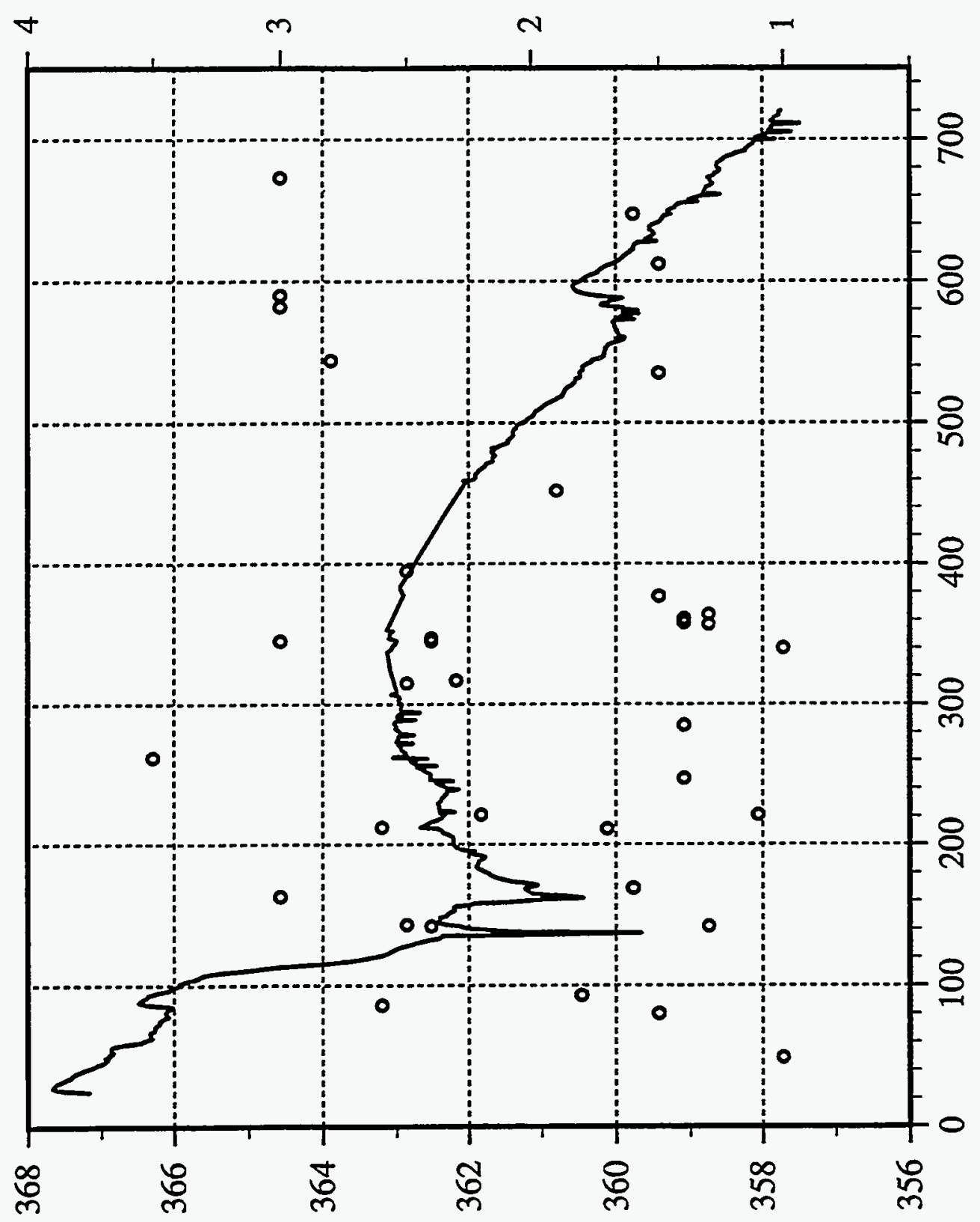

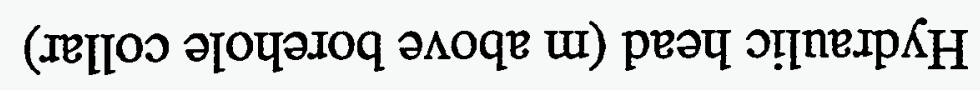




\section{Event magnitude (Richter)}

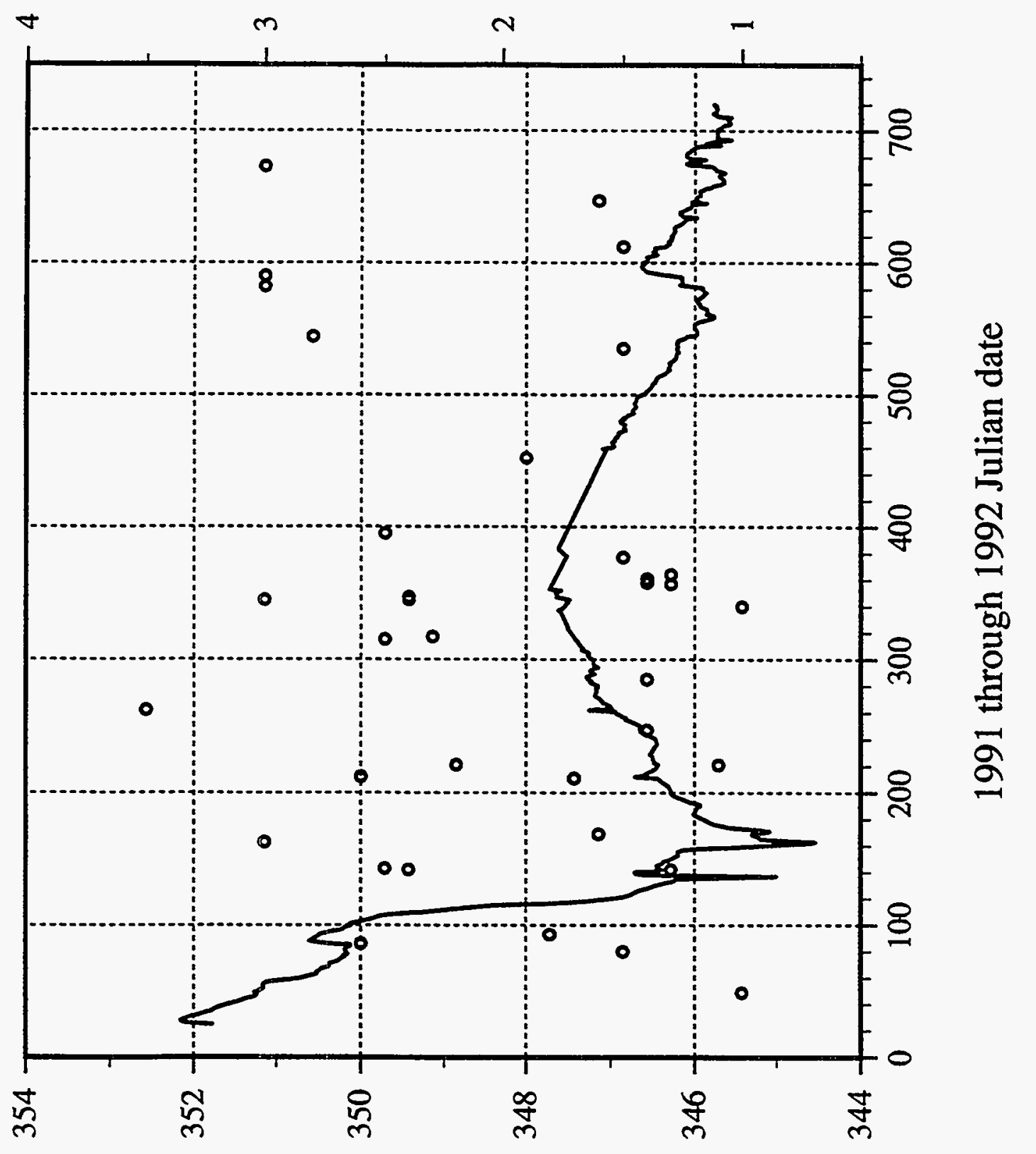

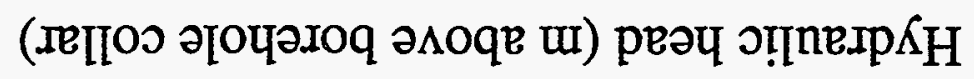


Event magnitude (Richter)

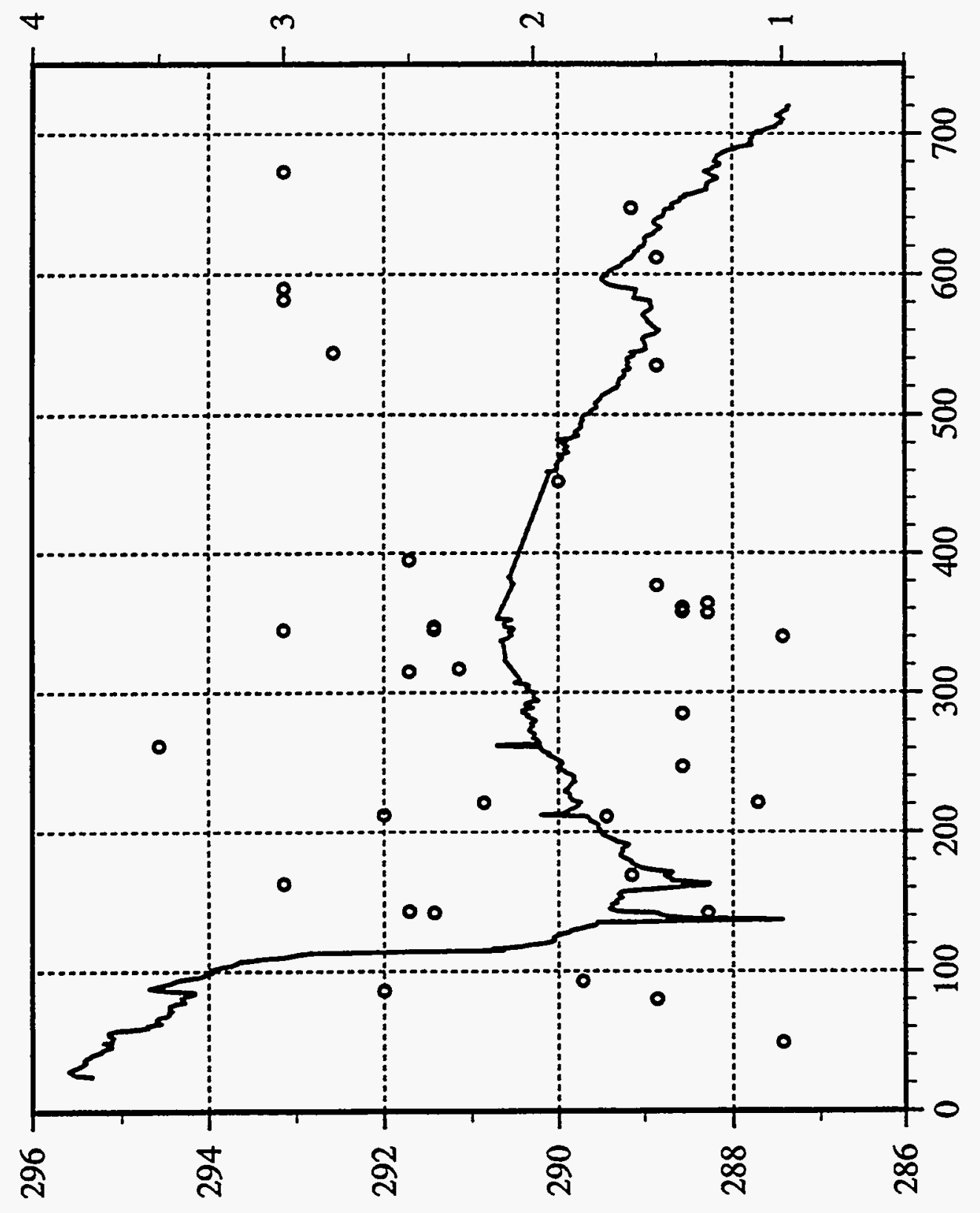

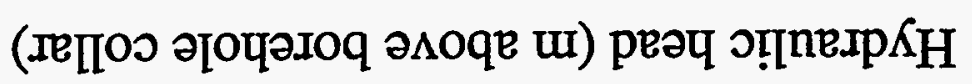

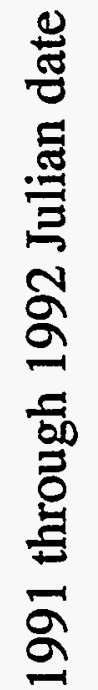


It is possible that normal seasonal hydrologic variations and long-term seismically induced hydrologic effects contributed to these changes. As was explained in Section 1.2, the data collected are not sufficient to permit a separation of the contributions of these three processes to the observed long-term changes in hydraulic head.

Short-term seismically induced changes did occur, which were associated with the various seismic events reported in Chapter 3. Some of these are noticeable in Figures $4-4$ to $4-9$, but some of them are not. Although the data were collected at an interval of $1 \mathrm{~min}$, these figures represent a day-by-day sampling of the measured data (at about noon each day) in order to improve clarity. Because most of the short-term seismic effects lasted for only a few hours, only those that occurred close to noon would be seen on plots such as these. More detailed plots showing the short-term seismic effects are presented in the next section.

\subsection{SHORT-TERM SEISMIC EFFECTS ON GROUNDWATER PRESSURE}

The primary difference between short- and long-term seismically induced changes in groundwater pressure is that the former build up and dissipate more rapidly than the latter. Both are caused by changes in the water-storage capacity, and sometimes permeability, of rock due to seismically induced deformation. On the other hand, whereas the short-term changes are related more to deformations associated with the seismic waves, the long-term changes are related more to deformations associated with the earthquakerelated static and dynamic stress changes that occur prior to, during, and after the seismic event. However, the two are not mutually exclusive; that is, most observed seismically induced changes in groundwater pressure are likely to involve both short- and long-term effects.

Figures 47, 4-8, and 4-9 show the groundwater pressure history for Zones 1, 2, and 3, respectively, for September 18 through 20,1991. An event of magnitude 3.5 on the Richter scale occurred at $0920 \mathrm{hr}$ on September 19, 1991. As the plots show, an increase in groundwater pressure occurred rapidly (almost instantaneously) at about the time of the event. The increase dissipated completely within 24 hours; more than half of the increase in Zones 2 and 3 dissipated during the first $3 \mathrm{hr}$ following the event. The groundwater pressure history shown in these plots display the typical characteristics of short-term seismic effects (i.e., rapid buildup and dissipation).

The next example, shown in Figures 4-10, 4-11, and 4-12, displays the characteristics of combined short- and long-term seismic effects, with the long-term effects probably dominant. The groundwater pressure histories shown in these plots are associated with a magnitude 2.6 seismic event that occurred at 0458 hours on March 27, 1991. As the plots show, an increase in groundwater pressure occurred, with a buildup time of about $3 \mathrm{~d}$ and a dissipation time of 8 to $12 \mathrm{~d}$. Although the groundwater pressure buildup and dissipation shown in these plots occurred over a relatively long time, it is possible to attribute it to the seismic event for two reasons. First, the build up started at about the same time as the event; it is unlikely that an increase in groundwater pressure related to seasonal variations or minebackfilling would begin to occur at the same time as a seismic event. Second, the increase is superimposed on a general trend of decreasing groundwater pressure, which suggests that it was caused by an event with hydrologic consequences against the ambient hydrologic trend.

A total of 18 seismic events with measurable hydrologic effects were observed during the hydrologic field studies. Plots of the groundwater pressure history associated with the events are given in Appendix $C$ (in addition to Figures 47 through 4-12). The groundwater pressure changes associated with 


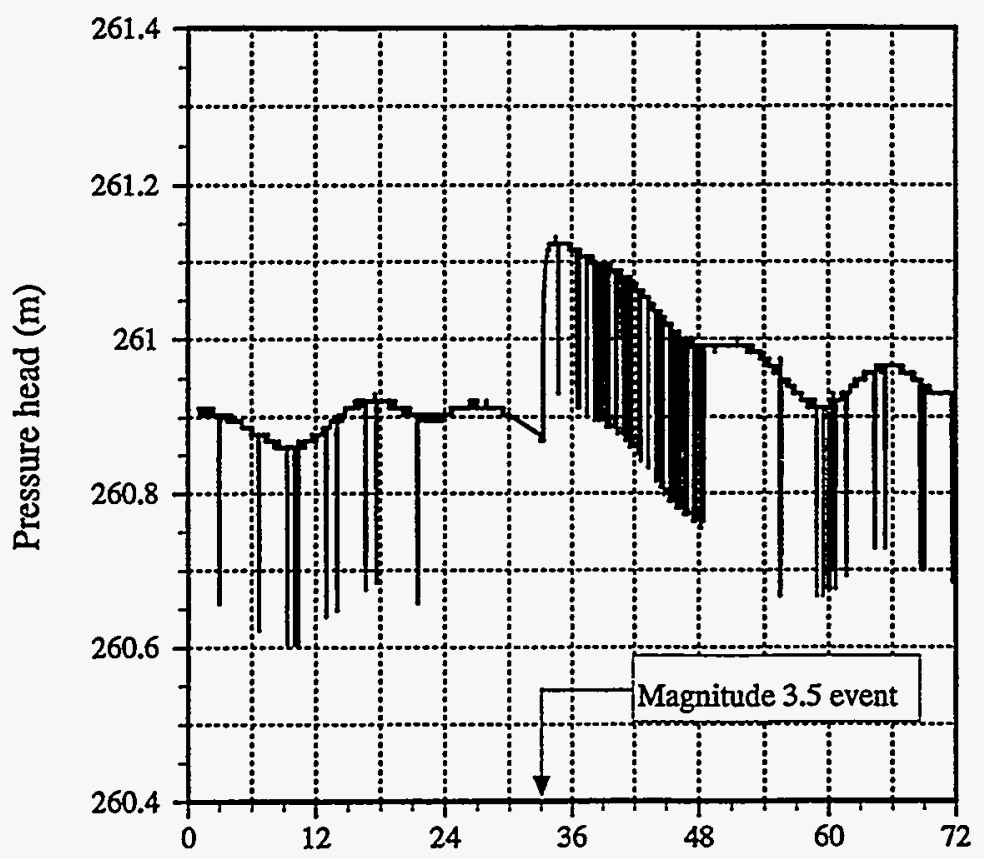

Hours (from midnight, September 17)

Figure 4-7. Groundwater pressure history for Zone 1, September 18 through 20, 1991

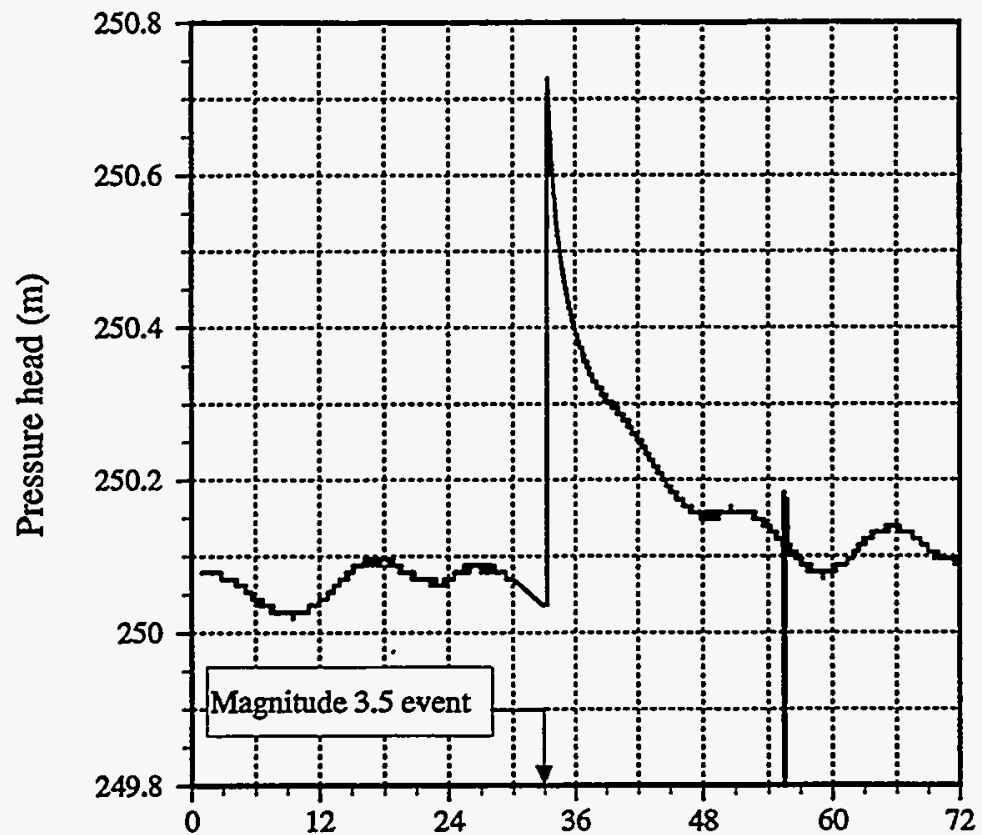

Hours (from midnight, September 17)

Figure 4-8. Groundwater pressure history for Zone 2, September 18 through 20, 1991 


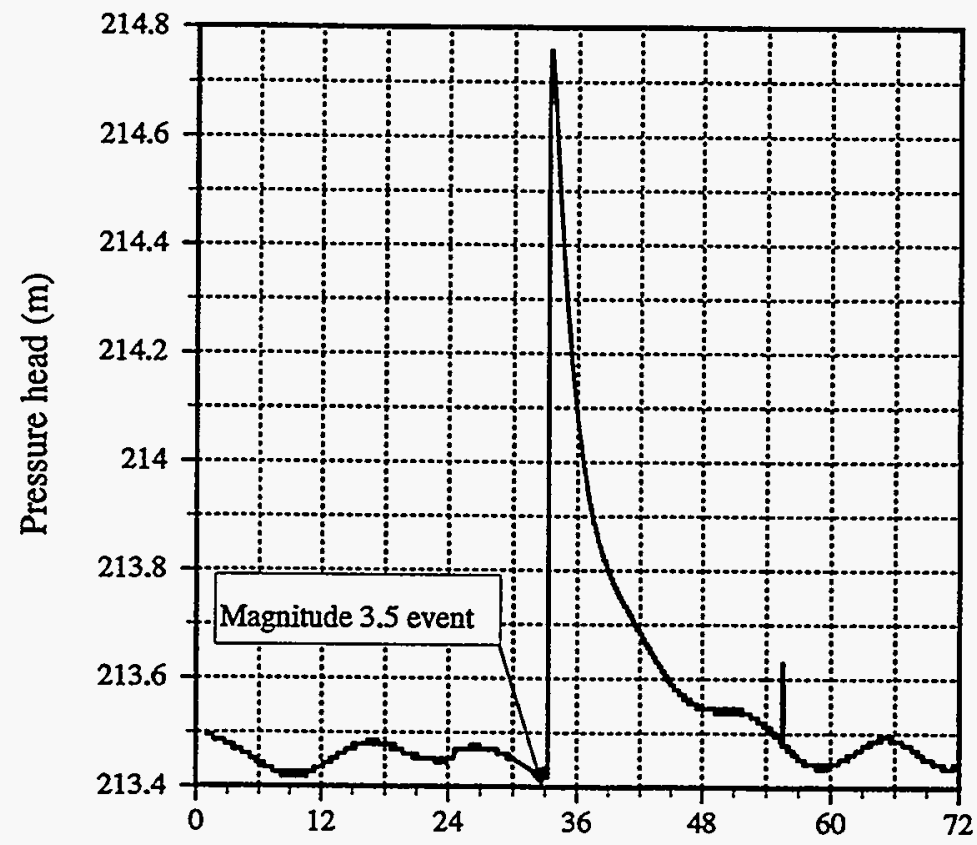

Hours (from midnight, September 17)

Figure 4-9. Groundwater pressure history for Zone 3, September 18 through 20, 1991

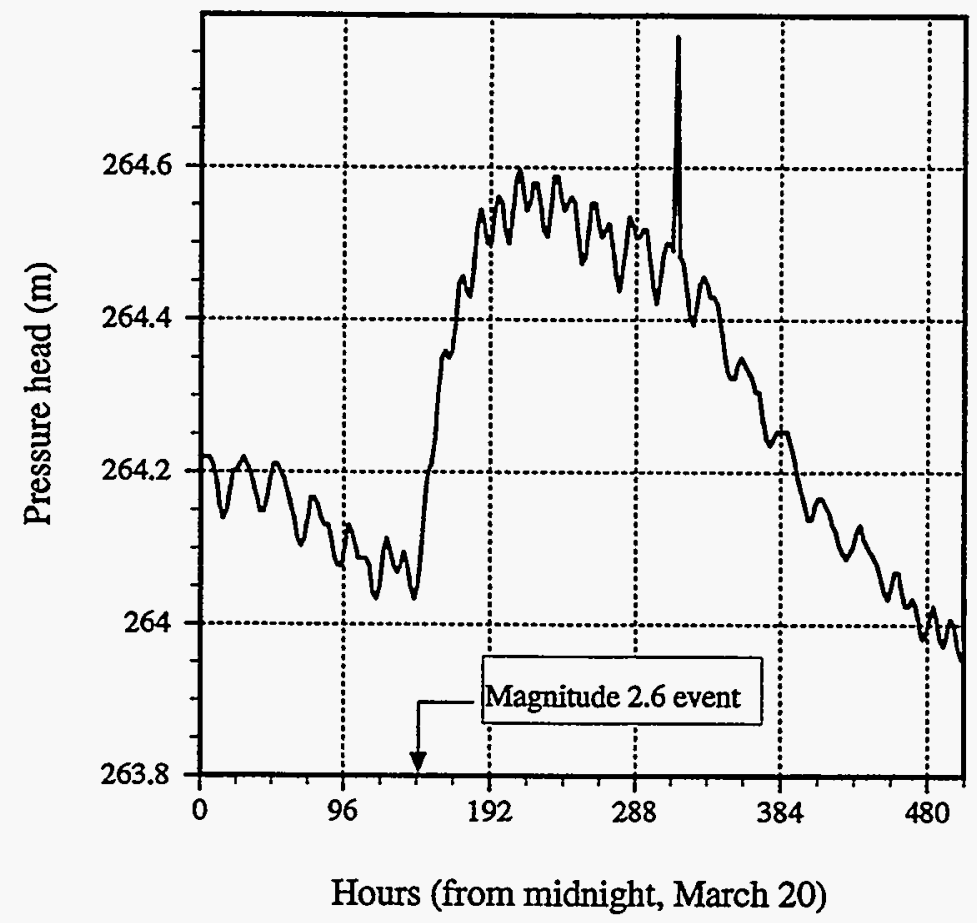

Figure 4-10. Groundwater pressure history for Zone 1, March 21 through April 10, 1991 


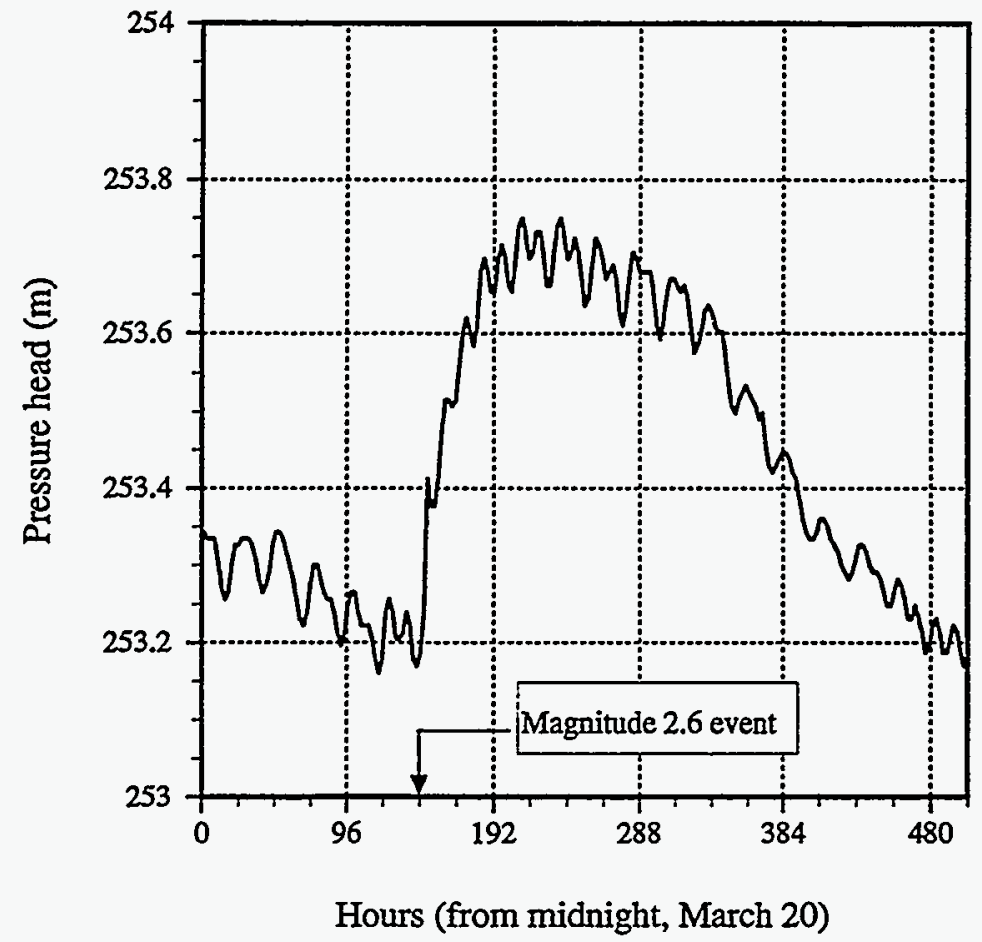

Figure 4-11. Groundwater pressure history for Zone 2, March 21 through April 10, 1991

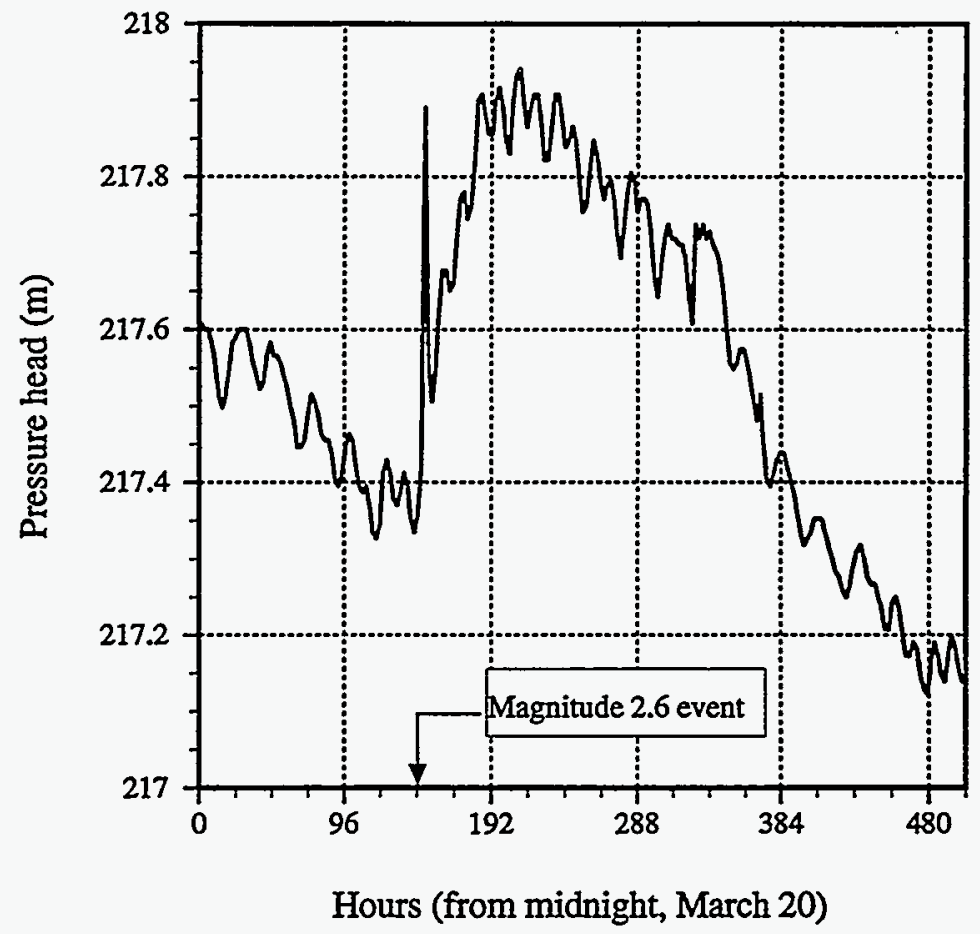

Figure 4-12. Groundwater pressure history for Zone 3, March 21 through April 10, 1991 
the events are summarized in Table 4-5, which gives the date, time, and magnitude of each event; the distance from the source location to the piezometer locations in Zones 1,2, and 3; and the associated change in groundwater pressure head for Zones 1, 2, and 3.

The magnitude of pressure head change, $\Delta h$, is expected to vary with the magnitude, $M_{w}$, of the seismic event, the distance, $\Delta r$, from the source to the point at which the effect is monitored, and other factors, such as the local storage capacity and permeability of the rock. Scatter plots of $\Delta h$ (log scale) versus $M_{w}$ are given in Figures 4-13, 4-14, and 4-15, for Zones 1, 2, and 3, respectively; and in Figure 4-16 for the combined data for all three zones. Also, scatter plots of $\Delta h$ versus scaled source distance, $\Delta r / \exp \left(M_{\psi} / 3\right)$ [cf. Hedley (1990); Hsiung et al. (1993)] are presented in Figures 4-17, 4-18, and 4-19, for Zones 1,2 , and 3, respectively, and in Figure 420 for the combined data for all three zones. These plots suggest that the magnitude of groundwater pressure change can be related to the seismic event magnitude and source distance. A series of multiple regression analyses were conducted using the statistical analysis code S-PLUS (StatSci, 1993), in an attempt to model the relationship between $\Delta h$, on the one hand, and $M_{w}$ and $\Delta r$, on the other. Two of the statistical models studied are discussed below. The first model uses a linear combination of functions which have been used previously [cf. Hedley (1990); Hsiung et al., (1993)] to represent the effects of earthquake magnitude and source distance on the observed response. The second model is based on a combination of general nonlinear functions, the nature of which is determined by the distribution of the observed data.

In the first model, the $\Delta h$ versus $M_{w}$ and $\Delta r$ relationship is described using the following equation

$$
\ln (\Delta h)=f\left(M_{w}\right)+g\left[\Delta r / \exp \left(M_{w} / 3\right)\right]
$$

where each of the functions $f()$ and $g()$ is a linear polynomial.

This model did not fit the observed data satisfactorily. The values of multiple $R^{2}$ coefficient obtained were $0.1650,0.2888$, and 0.4491 , for Zones 1,2 , and 3 data, respectively, and 0.2731 for the combined data. The $R^{2}$ coefficient is a measure of the appropriateness of the model. For example, the $R^{2}$ value of 0.4491 for Zone 3 implies that the model explains only about 44.91 percent of the observed data variation for that zone. Therefore, these $R^{2}$ values indicate that Eq. (4-2) is not an appropriate model for the data.

The measured values of $\Delta h$ are compared with the values predicted using Eq. (4-2) in Figures 421, 4-22, and 423, for Zones 1, 2, and 3, respectively, and in Figure 4-24 for the combined data for all three zones. The 1.0-slope line in each figure is the line of perfect agreement between the measured and predicted data. The predicted data are smaller than the measured data for points above the line, whereas they are larger for points below the line. The figures suggest that the model would be more successful in predicting small values of pressure head change than it would be in predicting large values. The model predictions deviate most from the measured values for values of $\Delta h$ larger than about $0.6 \mathrm{~m}$ in Zones 1 and 2, and $1.2 \mathrm{~m}$ in Zone 3; the predicted values in this range are consistently too small. As Table 4-5 shows, these values of pressure head change correspond to seismic events of magnitude 2.6 or larger.

The second model is based on the method of projection pursuit regression (Friedman and Stuetzle, 1981), as implemented in S-PLUS (StatSci, 1993). The value of $\Delta h$ corresponding to given values 
Table 4-5. Groundwater pressure changes associated with seismic events

\begin{tabular}{||c|c|c|c|c|c|c|c|c||}
\hline \multicolumn{3}{|c|}{ Seismic Events } & \multicolumn{3}{|c|}{ Source Distance (m) } & \multicolumn{2}{c|}{ Pressure Head Change (m) } \\
\hline Hour & Date & Magnitude & Zone1 & Zone2 & Zone3 & Zone1 & Zone2 & Zone3 \\
\hline \hline 0458 & $03 / 27 / 91$ & 2.6 & 1,403 & 1,397 & 1,375 & 0.6 & 0.6 & 0.6 \\
\hline 2124 & $05 / 22 / 91$ & 2.4 & 1,421 & 1,414 & 1,390 & 0.0 & 0.0 & 0.4 \\
\hline 0036 & $05 / 23 / 91$ & 2.5 & 1,422 & 1,416 & 1,391 & 0.3 & 0.15 & 0.2 \\
\hline 2203 & $06 / 12 / 91$ & 3.0 & 1,307 & 1,301 & 1,276 & 0.1 & 0.3 & 0.45 \\
\hline 2203 & $07 / 30 / 91$ & 1.7 & 1,382 & 1,376 & 1,354 & 0.1 & 0.15 & 0.32 \\
\hline 1204 & $07 / 31 / 91$ & 2.6 & 1,538 & 1,532 & 1,509 & 0.2 & 0.25 & 0.48 \\
\hline 1337 & $08 / 09 / 91$ & 2.2 & 1,404 & 1,398 & 1,375 & 0.17 & 0.17 & 0.34 \\
\hline 0920 & $09 / 19 / 91$ & 3.5 & 1,405 & 1,398 & 1,371 & 0.25 & 0.7 & 1.35 \\
\hline 0037 & $10 / 12 / 91$ & 1.4 & 1,403 & 1,397 & 1,371 & 0.08 & 0.12 & 0.18 \\
\hline 1337 & $12 / 11 / 91$ & 3.0 & 1,317 & 1,311 & 1,290 & -0.36 & 0.2 & 0.8 \\
\hline 1402 & $12 / 11 / 91$ & 2.4 & 1,295 & 1,289 & 1,267 & 0.1 & 0.15 & 0.19 \\
\hline 1336 & $12 / 13 / 91$ & 2.4 & 1,459 & 1,452 & 1,422 & 0.0 & 0.0 & 0.05 \\
\hline 1045 & $06 / 27 / 92$ & 2.8 & 1,441 & 1,434 & 1,410 & 0.02 & 0.05 & 0.15 \\
\hline 0226 & $08 / 04 / 92$ & 3.0 & 1,458 & 1,452 & 1,428 & 0.82 & 0.90 & 1.58 \\
\hline 0130 & $08 / 12 / 92$ & 3.0 & 1,384 & 1,378 & 1,354 & -0.15 & 0.12 & 0.63 \\
\hline 2037 & $09 / 03 / 92$ & 1.5 & 1,413 & 1,408 & 1,389 & 0.11 & 0.0 & 0.08 \\
\hline 0332 & $10 / 08 / 92$ & 1.6 & 1,473 & 1,466 & 1,438 & -0.05 & -0.05 & -0.05 \\
\hline 2121 & $11 / 03 / 92$ & 3.0 & 1,497 & 1,489 & 1,459 & 0.0 & 0.2 & 0.23 \\
\hline
\end{tabular}

of $M_{w}$ and $\Delta r$ is predicted using the following equation

$$
\Delta h=\overline{\Delta h}+\sum_{n=1}^{N o} \beta_{n} \theta_{n}\left(\left[\begin{array}{ll}
\alpha_{1 n} & \alpha_{2 n}
\end{array}\right]\left\{\begin{array}{c}
M_{w} \\
\Delta r
\end{array}\right\}\right)
$$

where the weight factors $\beta_{n}$, nonlinear transformation functions $\theta_{n}$, and unit vector components $\alpha_{1 n}$ and $\alpha_{2 \mathrm{n}}$ are computed using the statistical distribution of the observed values of $\Delta h, M_{w}$, and $\Delta r$, and $\overline{\Delta h}$ is the arithmetic mean of all the observed $\Delta h$. The parameter $N_{o}$ controls the degree of nonlinearity of the model. For example, a linear model is obtained with $N_{o}=1$. The value of $N_{o}$ was set to 3 for this analysis. 


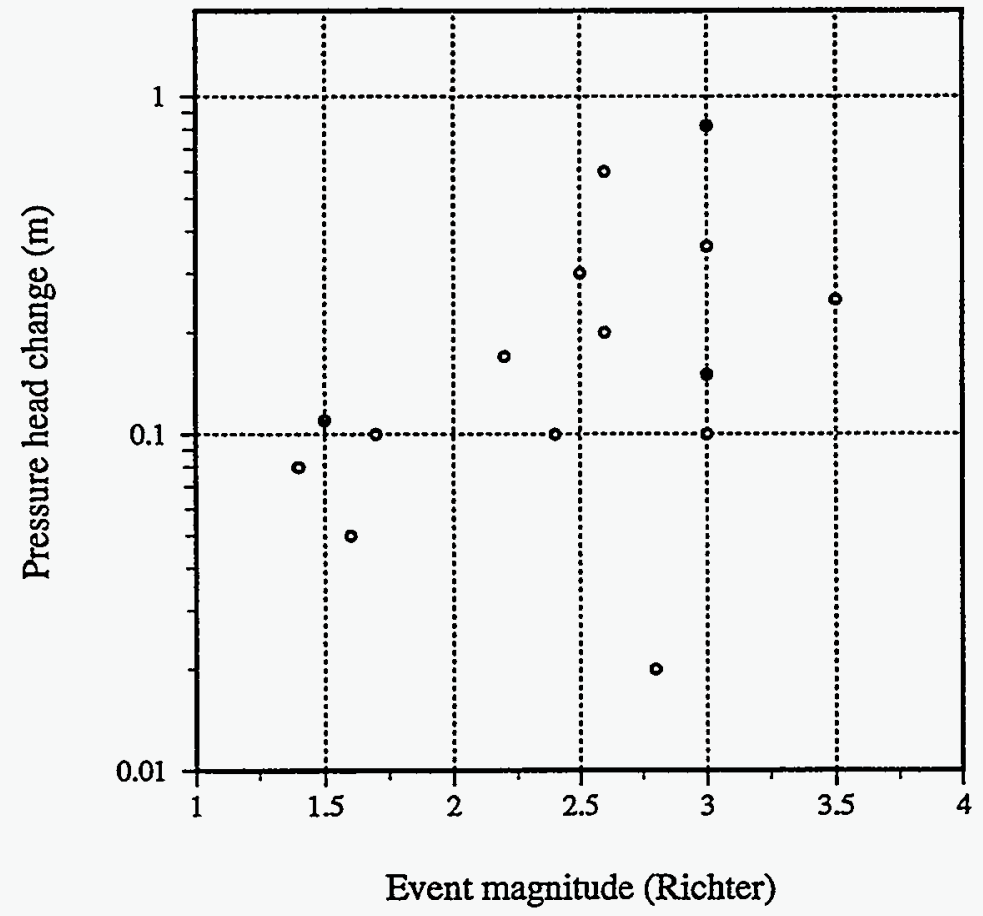

Figure 4-13. Scatter plot of change in groundwater pressure versus seismic event magnitude for Zone 1

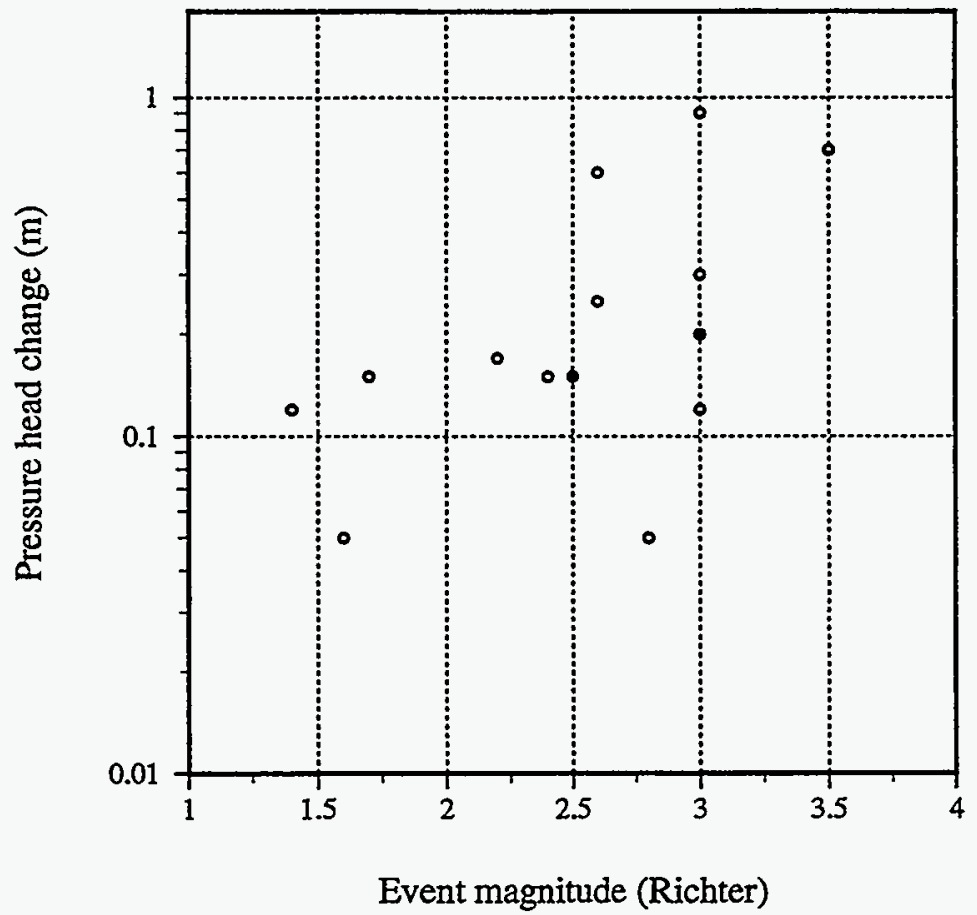

Figure 4-14. Scatter plot of change in groundwater pressure versus seismic event magnitude for Zone 2 


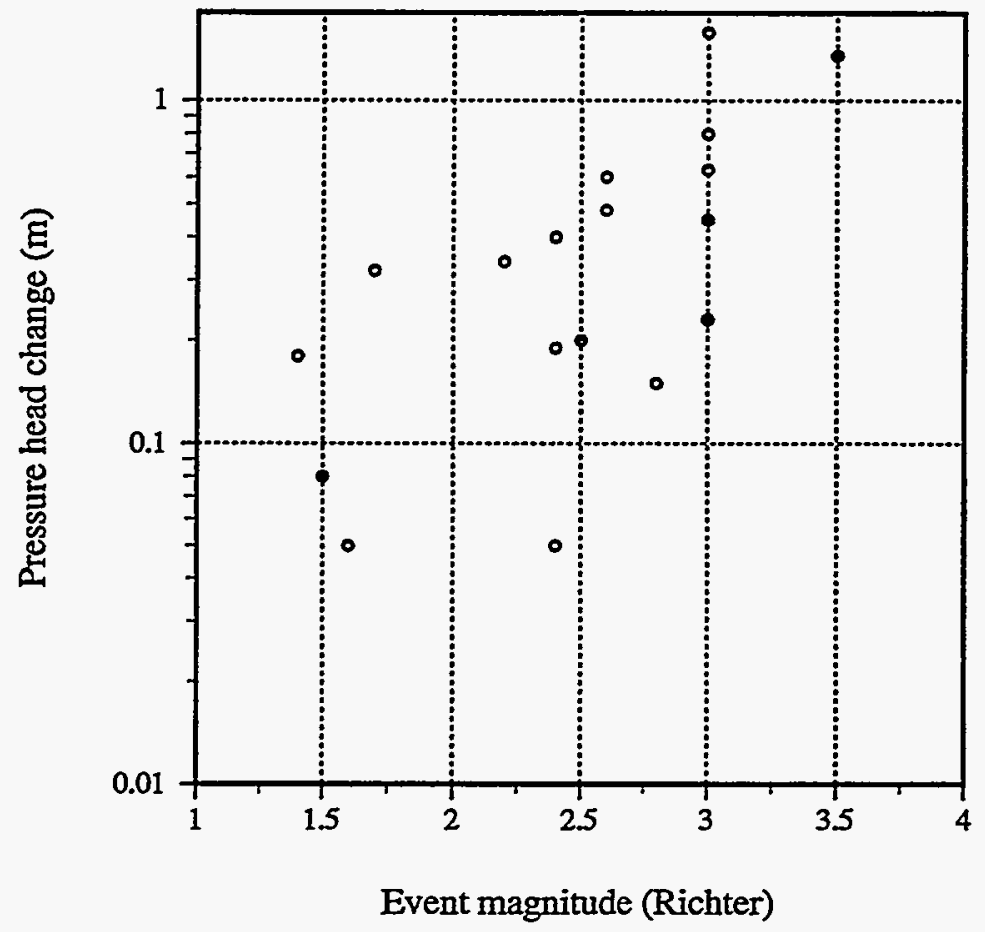

Figure 4-15. Scatter plot of change in groundwater pressure versus seismic event magnitude for Zone 3

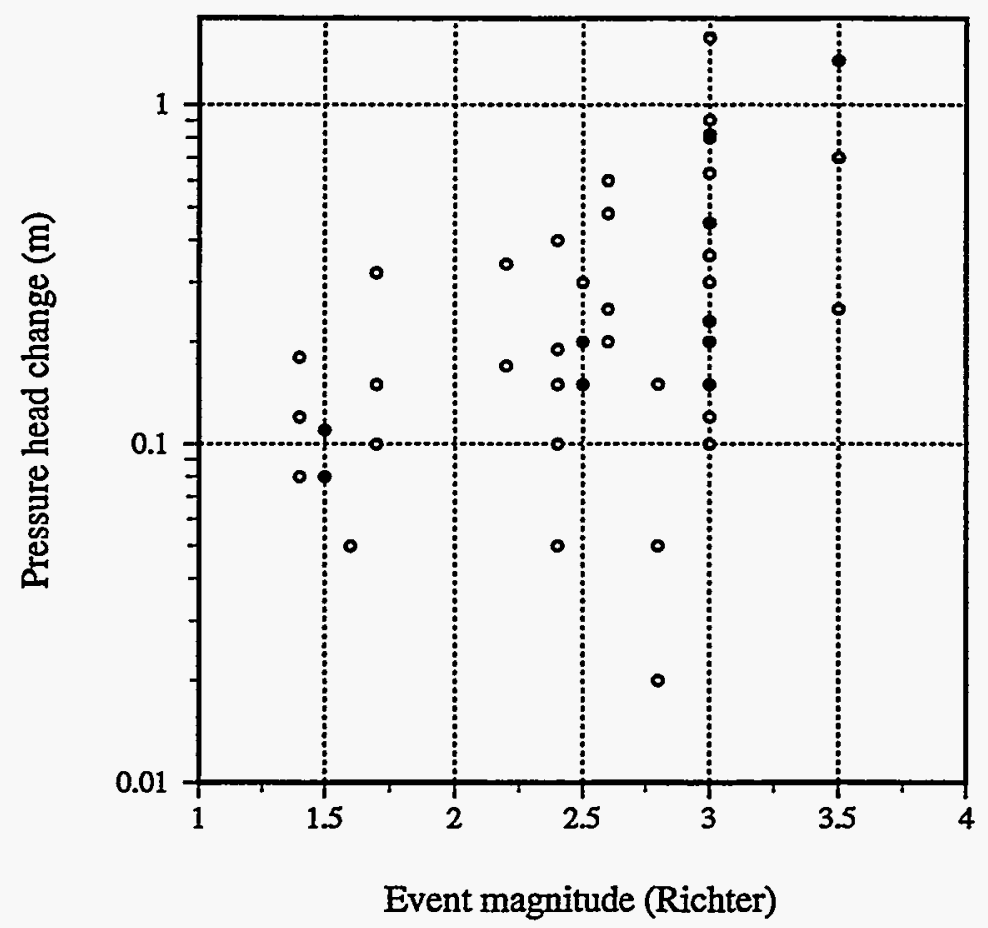

Figure 4-16. Scatter plot of change in groundwater pressure versus seismic event magnitude, including data for all three zones 


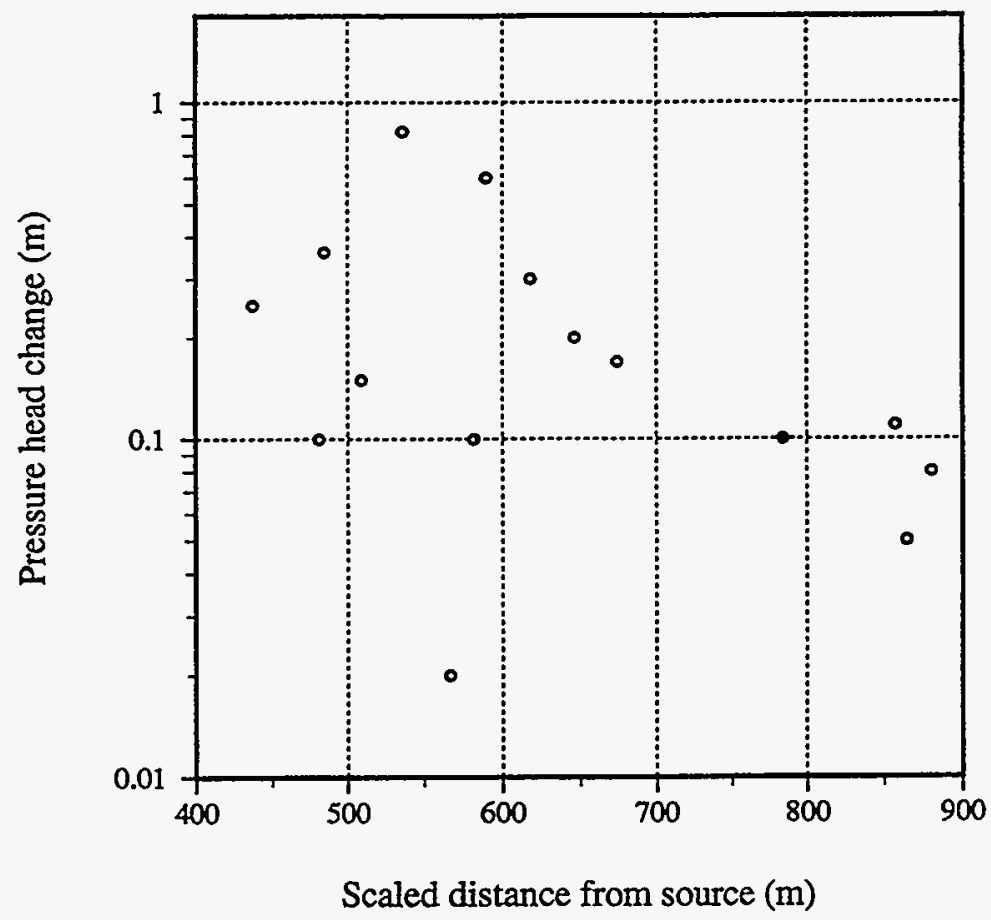

Figure 4-17. Scatter plot of change in groundwater pressure versus scaled source distance for Zone 1

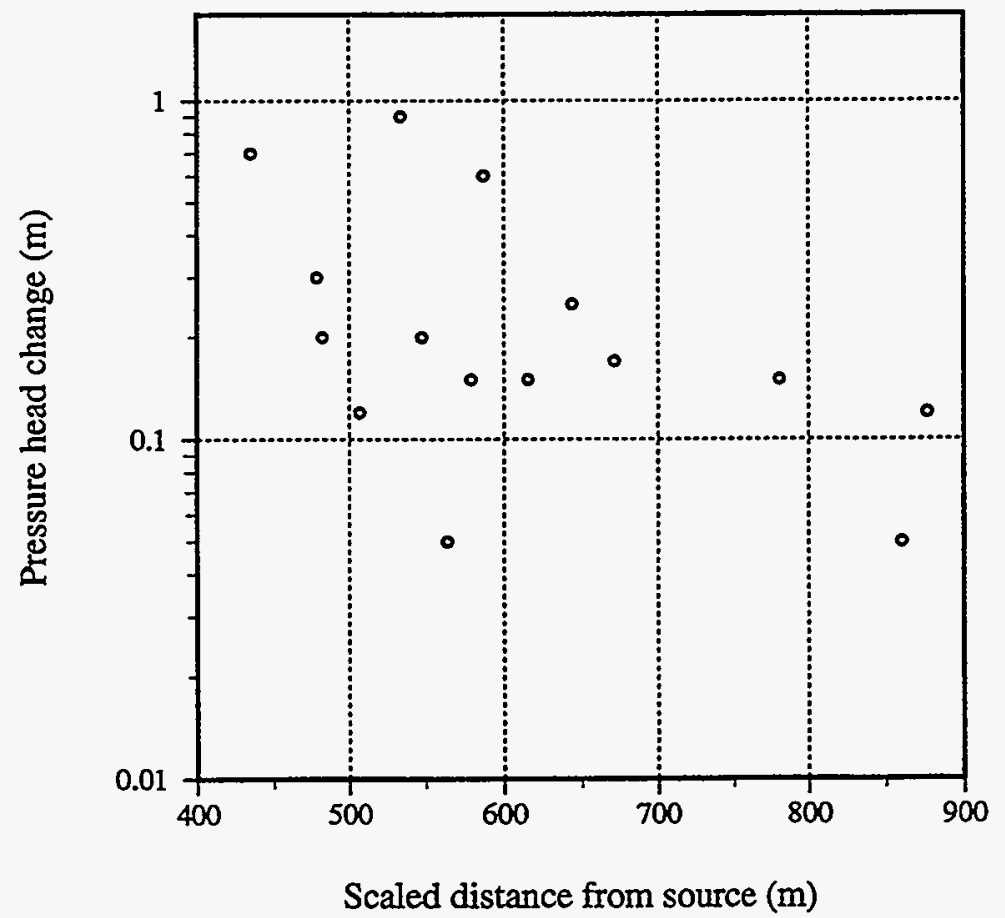

Figure 4-18. Scatter plot of change in groundwater pressure versus scaled source distance for Zone 2 


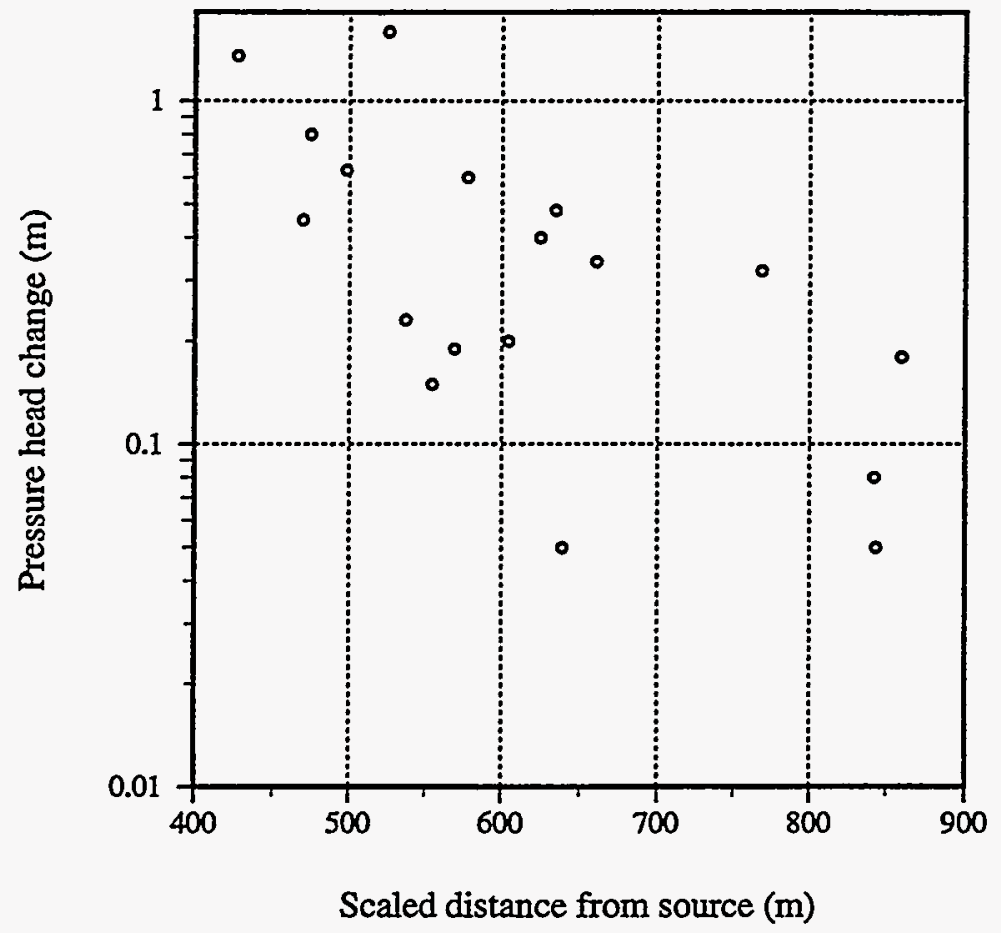

Figure 4-19. Scatter plot of change in groundwater pressure versus scaled source distance for Zone 3

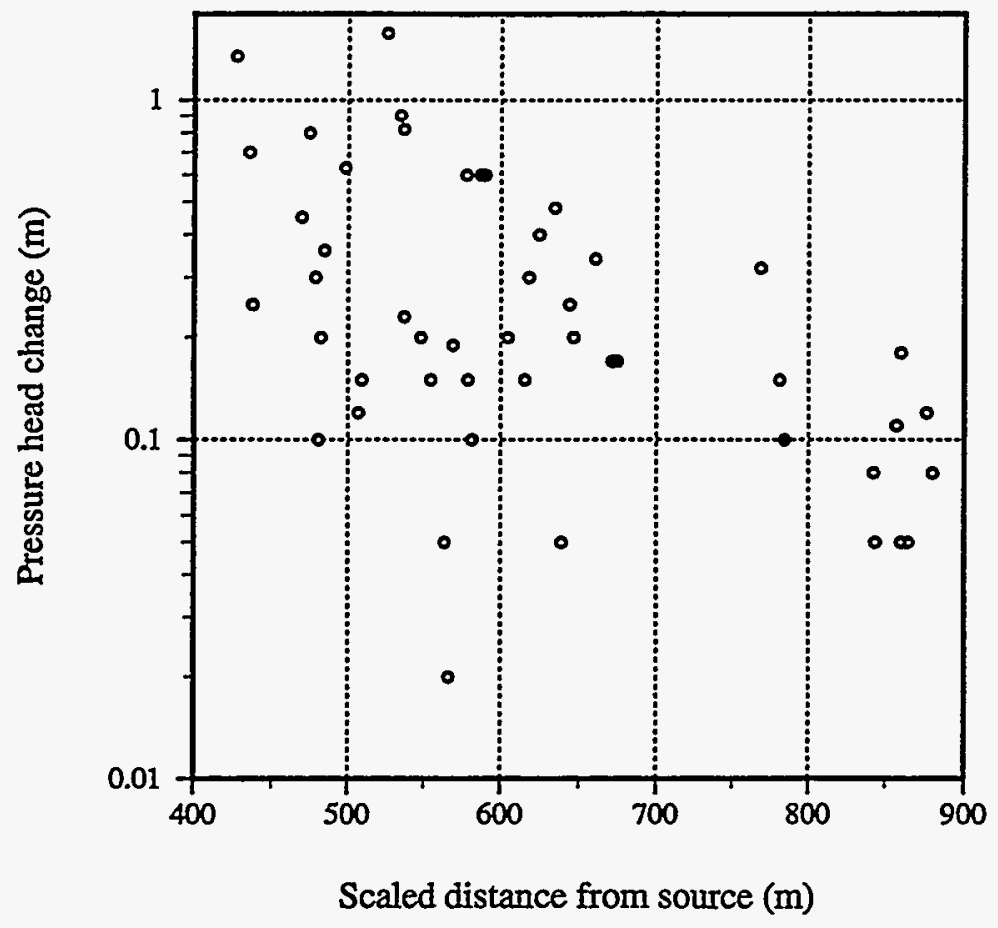

Figure 4-20. Scatter plot of change in groundwater pressure versus scaled source distance, including data for all three zones 


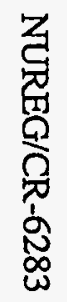
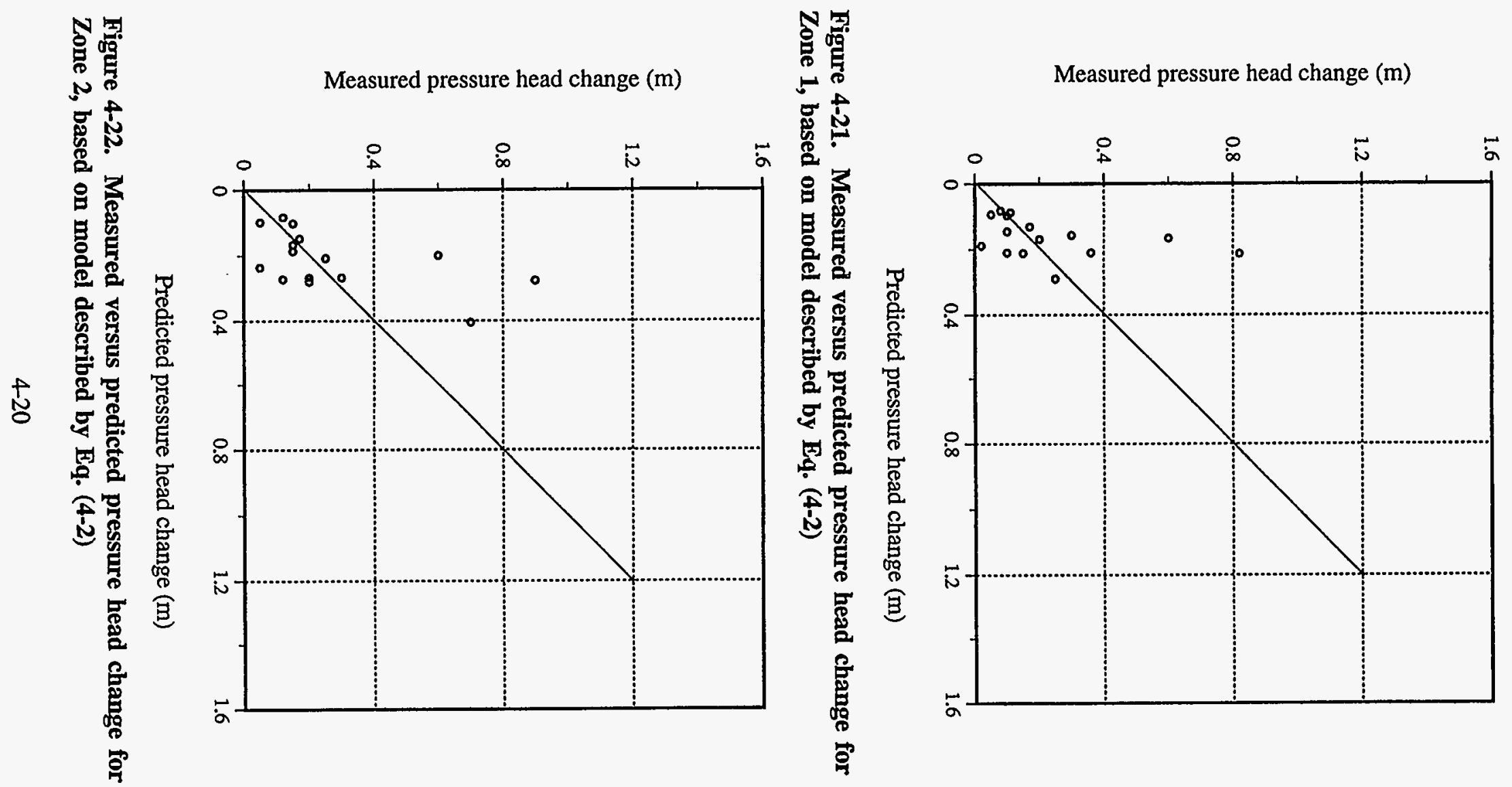


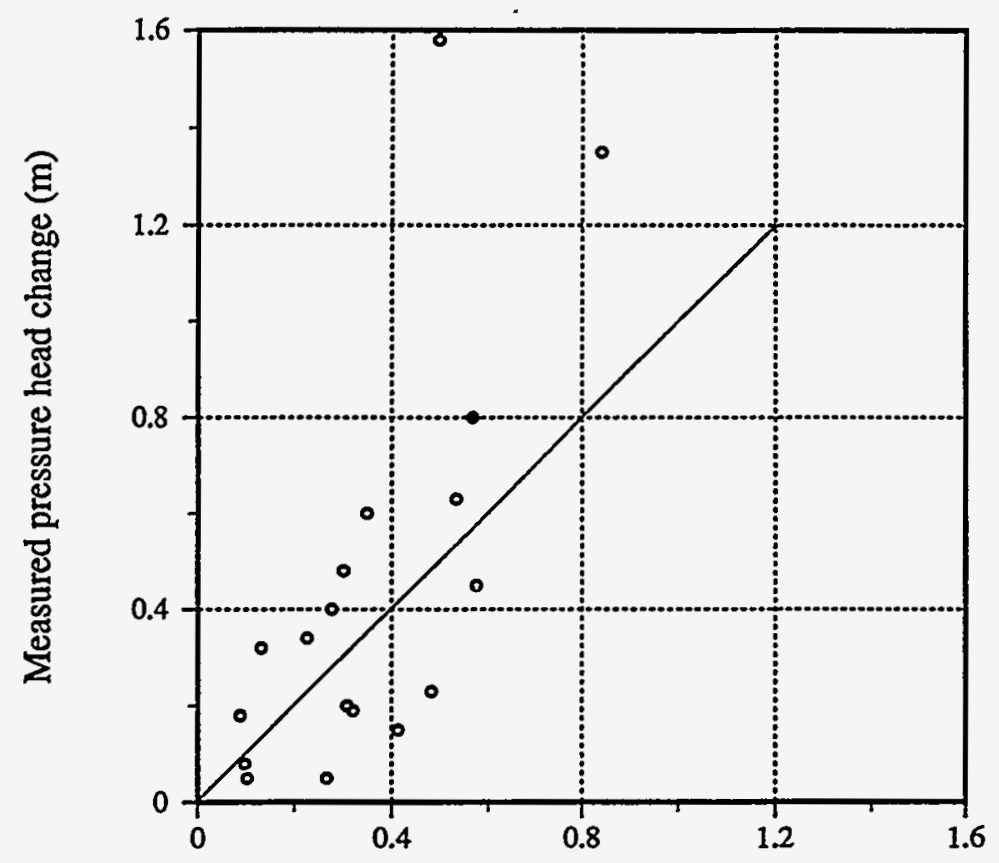

Predicted pressure head change (m)

Figure 4-23. Measured versus predicted pressure head change for Zone 3, based on model described by Eq. (4-2)

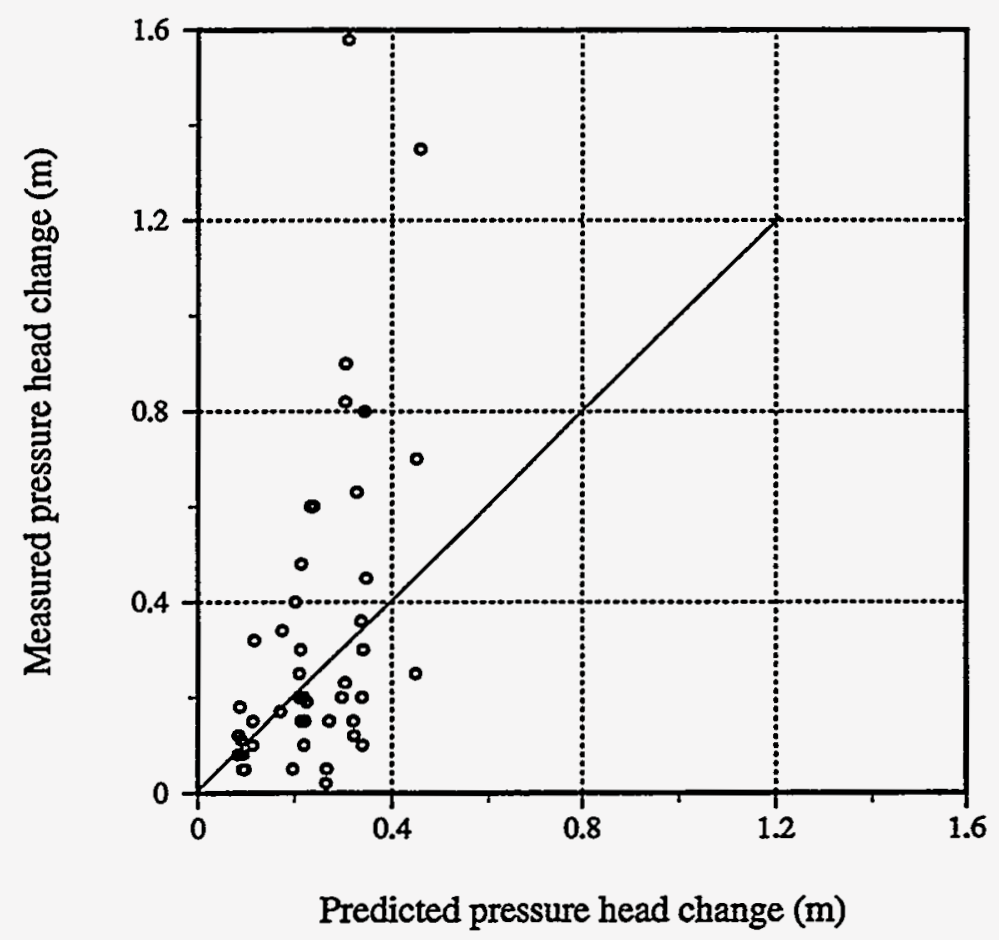

Figure 4-24. Measured versus predicted pressure head change for Zones 1, 2, and 3, combined, based on model described by Eq. (4-2) 
The values of $\Delta h$ predicted using this model are compared with the observed values in Figures 4-25, 4-26, and 4-27, for Zones 1, 2, and 3, respectively, and in Figure 4-28 for the combined data for all three zones. As these figures show, although the model represented by Eq. (4-3) fits the observed data much better than the previous model, the accuracy of its prediction decreases as the magnitude of pressure head change increases. As Figure 4-28 shows, all the observed values of $\Delta h$ larger than about $0.75 \mathrm{~m}$ lie above the 1.0-slope line. Table $4-5$ shows that values of $\Delta h$ larger than $0.75 \mathrm{~m}$ correspond to seismic events of magnitude 3.0 or larger.

Both statistical models examined above, despite the wide difference in their levels of sophistication, would not be satisfactory for predicting the groundwater pressure change due to seismic events of magnitude 3.0 or larger. Most of the data obtained in this study are for seismic events of smaller magnitude. The groundwater pressure change associated with small magnitude earthquakes is most likely caused by elastic deformations of rock fractures and pore spaces. As the earthquake magnitude increases, the contribution of inelastic deformations is likely to increase, and the severity of groundwater pressure changes is likely to increase at a rate larger than would be predicted based on observations of the effects of small magnitude earthquakes. It is necessary to combine small magnitude earthquake data, such as was obtained from this study, with data from larger magnitude earthquakes in order to better understand seismically induced hydrologic effects over a wide range of earthquake magnitudes. 


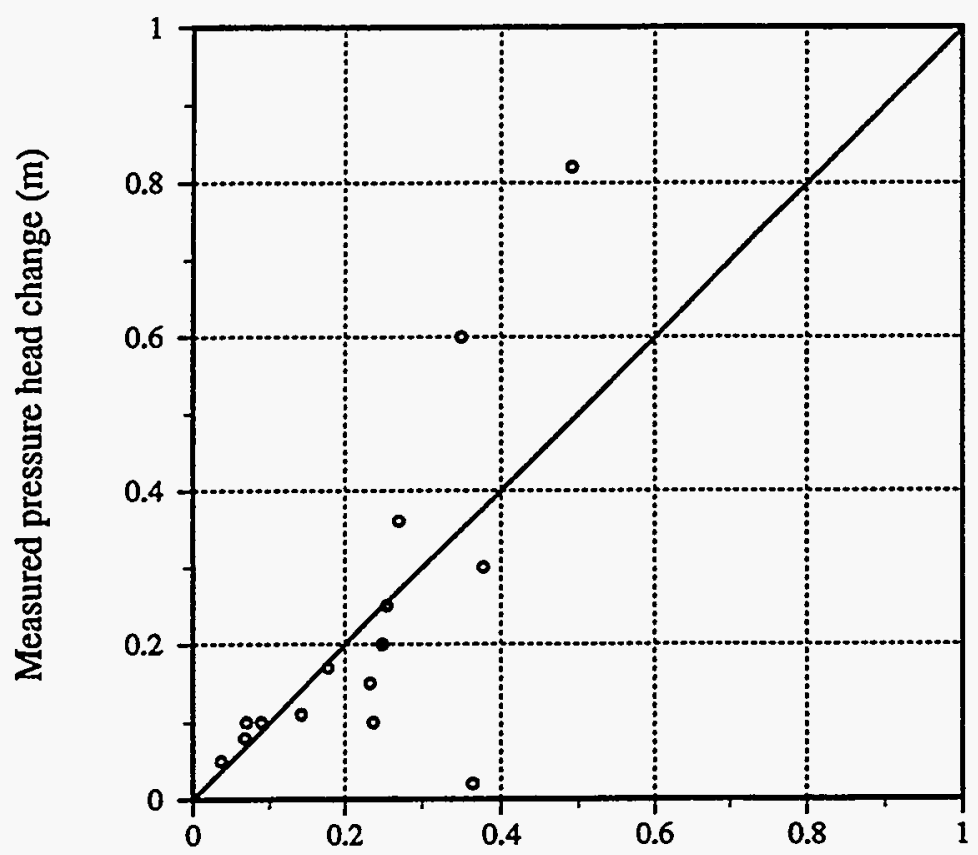

Predicted pressure head change (m)

Figure 4-25. Measured versus predicted pressure head change for Zone 1, based on model described by Eq. (4-3)

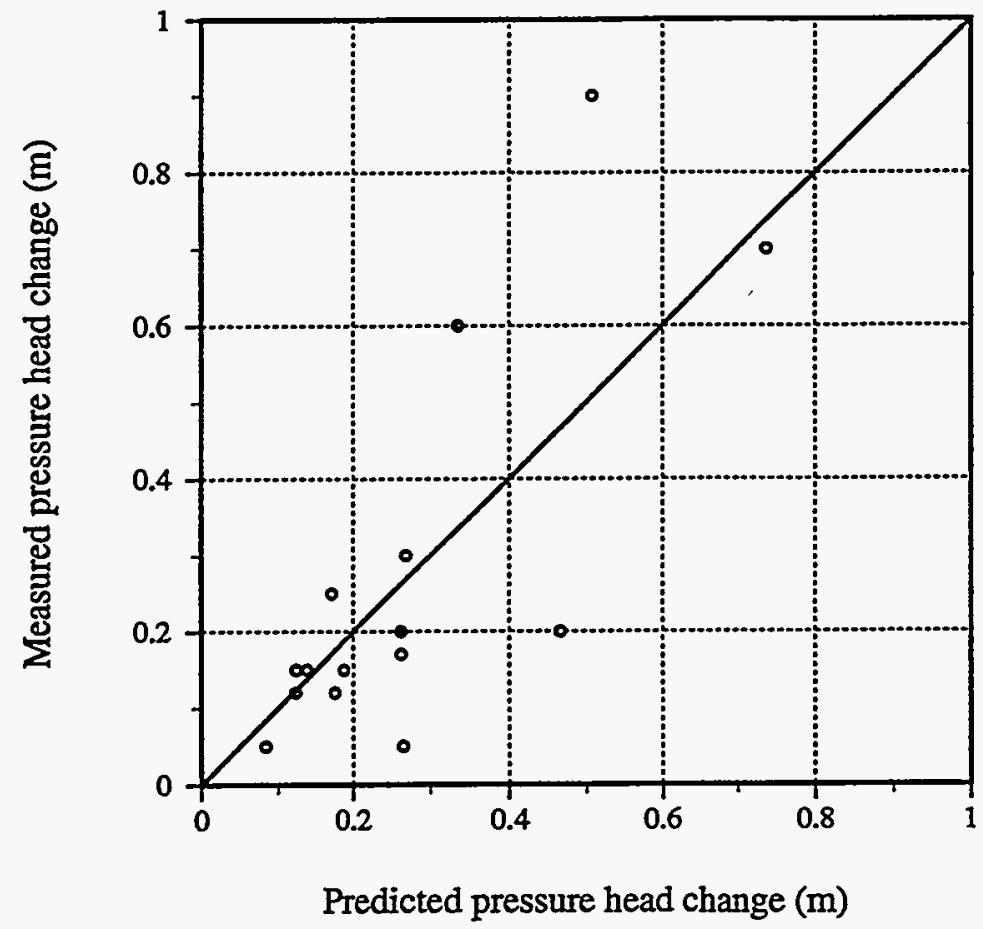

Figure 4-26. Measured versus predicted pressure head change for Zone 2, based on model described by Eq. (4-3) 


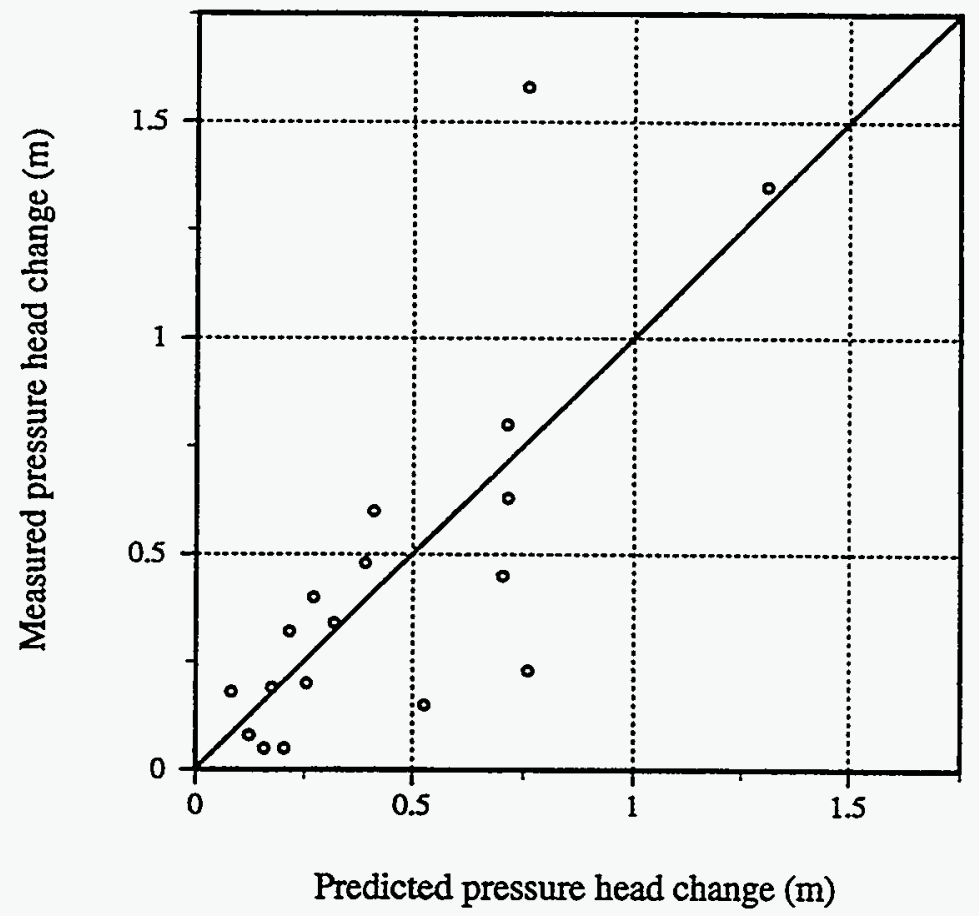

Figure 4-27. Measured versus predicted pressure head change for Zones 3, based on model described by Eq. (4-3)

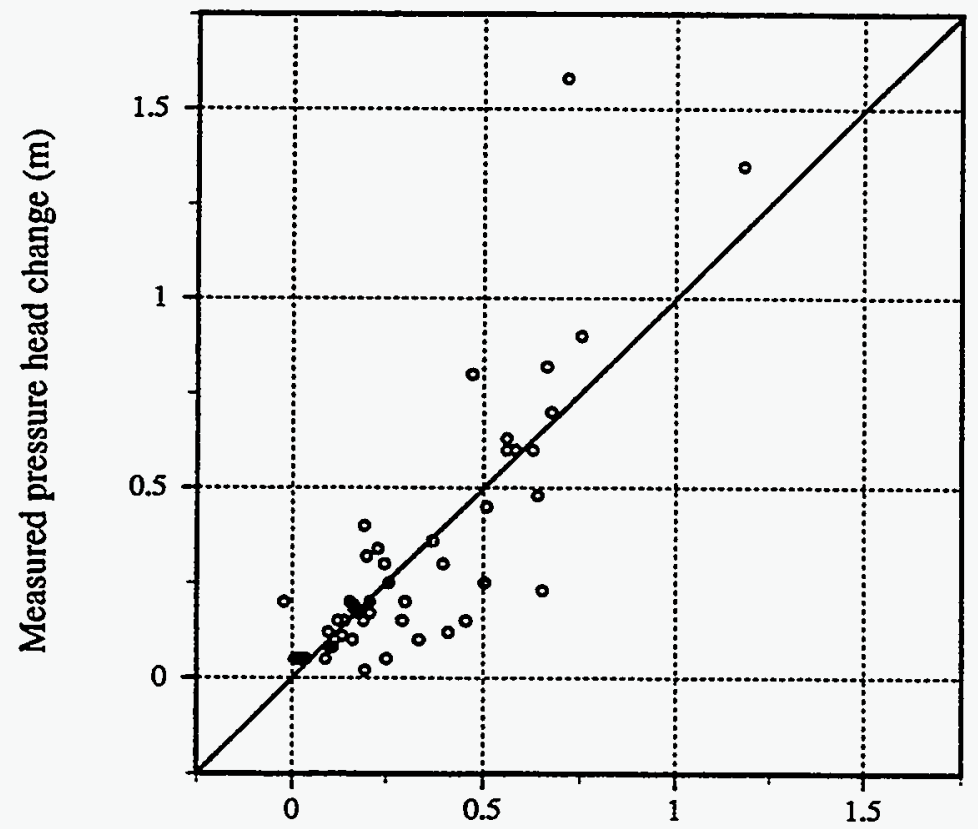

Predicted pressure head change (m)

Figure 4-28. Measured versus predicted pressure head change for Zones 1, 2, and 3, combined, based on model described by Eq. (4-3) 


\section{CONCLUSION}

Field data obtained at the Lucky Friday Mine support the notion that changes in groundwater pressure may occur in response to earthquakes. The magnitude of the groundwater pressure change increases as the earthquake magnitude increases; for a given earthquake magnitude, the change in groundwater pressure decreases as the distance of the observation point from the earthquake source increases. An attempt to model this relationship statistically was not successful: the majority of the data obtained were for earthquakes of magnitude 2.5 or smaller, and the statistical models examined could predict the effect of such earthquakes much better than that of larger magnitude earthquakes. The change in groundwater pressure predicted using the statistical models for earthquakes of magnitude 3.0 or larger is consistently smaller than the measured change for similar earthquakes. This observation suggests the conclusion that, in order to obtain a statistical model that would be applicable to a wide range of earthquake magnitudes, the database from which such a model would be derived needs to include data from a similar range of earthquakes.

Based on these results, it is suggested that the effect of earthquakes on groundwater flow may be better understood through mechanistic modeling, instead of the statistical modeling approach discussed above. The mechanical processes and material behavior that would need to be incorporated in the mechanistic model were examined in this report. An improved formulation of some of the processes and material behavior will need to be developed, and possibly incorporated in existing numerical codes, in order to develop the analytical capabilities required for the mechanistic modeling. 


\section{REFERENCES}

Ageton, R.L. 1967a. Deep Mine Stress Determinations Using Flatjack and Borehole Deformation Methods. Report of Investigations. RI 6887. Washington, DC: U.S. Bureau of Mines.

Ageton, R.L. 1967b. Stress Ellipsoid Determination in a Rock-Burst Prone Area at a 4,000-foot Depth, Galena Mine, Wallace, Idaho. Report of Investigations, RI 6997. Washington, DC: U.S. Bureau of Mines.

Ahola, M.P., L.J. Lorig, A.H. Chowdhury, and S. Hsiung. 1993. Thermo-Hydro-Mechanical Coupled Modeling: Near-field Repository Model, BMT3. CNWRA 93-002. San Antonio, TX: Center for Nuclear Waste Regulatory Analyses.

Bennett, E.H., P.L. Siems, and J.T. Constantopoulos. 1989. The geology and history of the Coeur d'Alene Mining District, Idaho. Guidebook to the Geology of Northern and Western Idaho and Surrounding Area. V.E. Chamberlain, R.M. Breckenridge, and B. Bonnichsen, eds. Moscow, ID: Idaho Geological Survey Bulletin 28: 137-156.

Beus, M.J., and S.S.M. Chan. 1980. Shaft Design in the Coeur d'Alene Mining District, Idaho-Results of In Situ Stress and Physical Property Measurements. Report of Investigations, RI 8435. Washington, DC: U.S. Bureau of Mines.

Beus, M.J., and S.S.M. Chan. 1985. Field Measurement and Finite Element Modeling of Circular and Rectangular Shaft Shapes in the Coeur d'Alene Mining District, Idaho. Report of Investigations, RI 8972. Washington, DC: U.S. Bureau of Mines.

Board, M.P., and M.J. Beus. 1989. In Situ Measurements and Preliminary Design Analysis for Deep Mine Shafts in Highly Stressed Rock. Report of Investigations, RI 9231. Washington, DC: U.S. Bureau of Mines.

Bower, D.R., and K.C. Heaton. 1978. Response of an aquifer near Ottawa to tidal forcing and the Alaskan earthquake of 1964. Canadian Journal of Earth Sciences 15(3): 331-340.

Chan, S.S.M. 1971. Deformation behavior of Revett Quartzite under uniaxial and triaxial loading. Proceedings of the 6th Canadian Rock Mechanics Symposium. Ottawa, Ontario: Department of Energy, Mines, and Resources: 9-31.

Chan, S.S.M., T.J. Crocker, and G.G. Waddell. 1972. Engineering properties of rocks and rock masses in the deep mines of the Coeur d'Alene Mining District, Idaho. Transactions, Society of Mining Engineers 252: 353-360.

de Costa, J.A. 1964. Effect of Hebgen Lake earthquake on water levels in wells in the United States. U.S. Geological Survey Prof. Paper 435(0): 167-178.

Friedman, J.H., and W. Stuetzle. 1981. Projection pursuit regression. Journal of the American Statistical Association 76: 817-823. 
Gianella, V.P., and E. Callaghan. 1934. The Cedar Mountain, Nevada earthquake of December 20, 1932. Bulletin of the Seismological Society of America 24(4).

Hauntz, C.E. 1982. Disseminated Sulfide Minerals (Blue-Rock) in the Revett Formation, Lucky Friday Mine, Mullan, Idaho. M.S. Thesis. Moscow, ID: University of Idaho, Department of Geological Engineering.

Hedley, D.G.F. 1990. Peak particle velocity for rockbursts in some Ontario mines. Rockbursts and Seismicity in Mines. C. Fairhurst, ed. Rotterdam, Holland: A.A. Balkema.

Hsiung, S.M., and A.H. Chowdhury. 1991. Seismic Rock Mechanics. Report on Research Activities for Calendar Year 1990. W.C. Patrick, ed. NUREG/CR-5718. Washington, DC: Nuclear Regulatory Commission.

Hsiung, S.M., A.H. Chowdhury, W. Blake, M.P. Ahola, and A. Ghosh. 1992. Field Site Investigation: Effect of Mine Seismicity on a Jointed Rock Mass. CNWRA 92-012. San Antonio, TX: Center for Nuclear Waste Regulatory Analyses.

Hsiung, S.M., A.H. Chowdhury, W. Blake, and J. Philip. 1993. Field investigation of mining-induced seismicity on local geohydrology. Proceedings of the Fourth International Conference on High Level Radioactive Waste Management. La Grange Park, IL: American Society of Civil Engineers: 1: 913-920.

Jones, J.C. 1915. The Pleasant Valley, Nevada, earthquake of October 2, 1915. Bulletin of the Seismological Society of America 5(4): 190-205.

Jenkins, F.M., T.J. Williams, and C.J. Wideman. 1990. Rockburst mechanism studies at the Lucky Friday Mine. Proceedings, 31st United States Symposium on Rock Mechanics. Golden, CO: Colorado School of Mines: 955-962.

Kemeny, J., and N. Cook. 1990. Rock mechanics and crustal stress. Demonstration of Risk-Based Approach to High-Level Waste Repository Evaluation. R.K. McGuire, ed. EPRI NP-7057. Golden, CO: Risk Engineering Inc: 5-1 to 5-20.

Miller, C.H., and E.H. Skinner. 1980. The nature of fracturing and stress distribution in quartzite around the 1128-m (3,700-ft.) level of the Crescent Mine, Coeur d'Alene Mining District, Idaho. Engineering Geology 16: 321-338.

Muir-Wood, R., and G.C.P. King. 1993. Hydrologic signatures of earthquake strain. Journal of Geophysical Research 98(B12): 22,035-22,068.

National Academy of Sciences/National Research Council. 1992. Groundwater at Yucca Mountain: How High Can It Rise? Washington, DC: National Academy Press.

Nur, A. 1974. Matsushiro, Japan, earthquake swarm: confirmation of the dilatancy-fluid diffusion model. Geology 2: 217-221. 
O'Brien, G.M. 1993. Earthquake-Induced Water-Level Fluctuations at Yucca Mountain, Nevada, June 1992. U.S. Geological Survey Open-File Report 93-97. Denver, CO: U.S. Geological Survey.

Pariseau, W.E., and H. Moon. 1987. Influence of "Joints" on LFUL Stope Stability. Final Report. U.S. Bureau of Mines. Spokane, WA: Spokane Research Center.

Raney, R.G. 1988. Reported Effects on Selected Earthquakes in the Western North American Intermountain Region, 1852-1983, on Underground Workings and Local and Regional Hydrology: A Summary. Spokane, WA: U.S. Bureau of Mines.

Rojstaczer, S., and S. Wolf. 1992. Permeability changes associated with large earthquakes: an example from Loma Prieta, California. Geology 20: 211-214.

Schipke, P.H. 1972. Experimental Determination of the Dynamic Elastic Properties of Revett Quartzite Exhibiting Orthotropic Anisotropy. M.S. Thesis. Rapid City, SD: South Dakota School of Mines and Technology.

Skinner, E.H., G.G. Waddell, and J.P. Conway. 1974. In Situ Determination of Rock Behavior by Overcore Stress Relief Method, Physical Property Measurements, and Initial Deformation Method. Report of Investigations. RI 7962. Washington, DC: U.S. Bureau of Mines.

Slemmons, D.B. 1956. Damage caused by the earthquakes of 1954. Bulletin of the Seismological Society of America 46(1).

Sprenke, K.F., and W.R. Hammond. 1988. Macroseismic Monitoring System Design: Parts 1 and 2. Final Contract Report No. S0278057. Moscow, ID: University of Idaho.

StatSci, 1993. S-PLUS Guide to Statistical and Mathematical Analysis. Seattle, WA: MathSoft Inc.

Szymanski, J.S. 1989. Conceptual Considerations of the Yucca Mountain Groundwater System with Special Emphasis on the Adequacy of this System to Accommodate a High-Level Nuclear Waste Repository. Las Vegas, NV: U.S. Department of Energy.

Thrupp, G.A., D.R. Wuthrich. 1994. Earthquake-induced water level fluctuation recorded in Chino Basin Wells (abstract). Presented at the 89th Annual Meeting of the Seismological Society of America April 5-7, 1994. Pasadena, CA: Pasadena Convention Center.

U.S. Department of Energy. 1988. Site Characterization Plan: Yucca Mountain Site, Nevada Research and Development Area, Nevada. Washington, DC: U.S. Department of Energy, Office of Civilian Radioactive Waste Management.

Waddell, G.G. 1966. In Situ Measurement of Rock Deformation in a Vein-Type Deep Mine-1. Instrumentation and Techniques; 2. Analysis of Measurements in the Star Mine, Burke, Idaho. Report of Investigations, RI 6747. Washington, DC: U.S. Bureau of Mines. 
Waller, R.M. 1966. Effects of the March 1964 Alaska Earthquake on the Hydrology of the Anchorage Area. United States Geological Survey Professional Paper 544-B. Washington, DC: U.S. Government Printing Office.

White, B.G., and D. Winston. 1977. The Revett-St. Regis "transition zone" near the Bunker Hill mine, Coeur d'Alene District, Idaho. Society of Economic Geologists' Coeur d'Alene Field Conference. Golden, CO: 25-30.

Whyatt, J.K. 1986. Geomechanics of the Caladay Shaft. M.S. Thesis. Moscow, ID: University of Idaho, Department of Mining Engineering.

Williams, T.J., and D.J. Cuvelier. 1988. Report on a field trial of an underhand longwall mining method to alleviate rockburst hazards. Proceedings of the 2nd International Symposium on Rockbursts and Seismicity in Mines. C. Fairhurst, ed. Minneapolis, MN: University of Minnesota: 349-353.

Wood, S.H., C. Wurts, T. Lane, N. Ballenger, M. Shaleen, and D. Totorica. 1985. The Borah Peak, Idaho earthquake of October 28, 1983 - hydrologic effects. Earthquake Spectra 2(1): 127-150.

Zones, C.P. 1957. Changes in hydrologic conditions in the Dixie Valley and Fairview Valley areas, Nevada, after the earthquake of December 16, 1954. Bulletin Society of America 47(4): 387-396. 
APPENDIX A

LABORATORY DETERMINATION OF INTACT ROCK PROPERTIES

NUREG/CR-6283

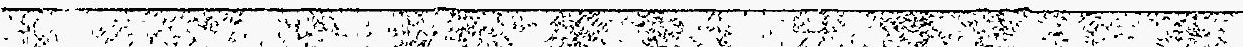




\section{A. LABORATORY DETERMINATION OF INTACT ROCK PROPERTIES}

Laboratory tests were conducted to obtain location specific material property data on the intact rock, in addition to the existing data sources referred to in Section 2.2 of the main text. Tests were conducted to obtain data on the elastic stiffness (in terms of Young's modulus and Poisson's ratio), and tensile and compressive strength. Three types of laboratory tests were conducted: (i) unconfined compression test (UCT), (ii) triaxial test (TT), and (iii) Brazilian test (BT).

\section{A.1 SPECIMEN SELECTION AND PREPARATION}

All the specimens were cored from boreholes drilled for instrument installation. One set of specimens was obtained from the mechanical response monitoring sites, LFM95-C1 and LFM95-C2 (Hsiung et al., 1992). The core recovery from these sites was very low; as a result, only 16 BT and 17 UCT and TT specimens could be obtained from the two sites. The second set of specimens was obtained from the groundwater response borehole (see Figure 4-2 of main text). A total of 24 BT and 40 UCT and TT specimens were selected from this site. All the specimens are fine-grained vitreous quartzite, of the Lower Revett Formation.

Each specimen was assigned an identification number, in accordance with CNWRA TOP-012, Technical Operating Procedure for the Identification, Control Storage, Handling, Shipping, and Archiving of Samples. The nominal diameter of the specimens was $50.8 \mathrm{~mm}(2 \mathrm{in}$.). Their finished length-to-diameter ratios and the smoothness of their end and cylindrical surfaces were required to satisfy the following standards:

1. ASTM D-2938-79: Standard test method for unconfined compressive strength of intact rock core specimens.

2. ISRM (1979): Suggested methods for determining the uniaxial compressive strength and deformability of rock materials.

3. ASTM D-2664-80: Standard test method for triaxial compressive strength of undrained rock core specimens without pore pressure measurements.

4. ISRM (1978a): Suggested methods for determining the strength of rock materials in triaxial compression.

5. ASTM D-3967-81: Standard test method for splitting tensile strength of intact rock core specimens.

6. ISRM (1978b): Suggested methods for determining tensile strength of rock materials.

The laboratory tests were conducted at the Geomechanics laboratory of the Department of Mining and Geological Engineering, University of Arizona. The tests were conducted in accordance with the testing procedure specified in Daemen (1990). ${ }^{1}$

${ }^{1}$ Daemen, J. 1990. Quality Assurance Program for Mechanical Characterization of Tuff, CNWRA. Letter report to CNWRA. 


\section{A.2 LABORATORY TEST RESULTS}

The test results are presented in Tables A-1 through A-4 and Figures A-1 through A-4. The large variations in the values of mechanical properties calculated from the data are believed to be caused by variations in rock material characteristics, such as pre-existing microcrack density and inter-granular fabric. Similar mechanical property variability was reported by Whyatt (1986), as is discussed in Section 2.2 of the main report.

\section{A.2.1 Elastic Stiffness and Unconfined Compressive Strength}

A total of 47 specimens were tested in uniaxial compressive, 10 of which were strain gaged to permit the measurement of axial and circumferential strains, as well as axial stress. Of the specimens, nine failed to satisfy the standards in ASTM D-2938-79 (including six specimens that did not satisfy the standard for smoothness of cylindrical surface, because of diamond drilling irregularity). All the data are summarized in Tables A-1 and A-2. The mean and standard deviations, based on the 38 specimens that satisfied the ASTM standard, are: 181 and $81 \mathrm{MPa}$, respectively, for the unconfined compressive strength; $5.23 \times 10^{4}$ and $1.88 \times 10^{4} \mathrm{MPa}$, respectively, for the Young's modulus; and 0.174 and 0.044 , respectively, for the Poisson's ratio. The statistical distributions of the data are summarized in Figures A-1, A-2, and A-3.

\section{A.2.2 Triaxial Compressive Strength}

Ten specimens were tested in triaxial compression, under values of confining pressure of 3.45 , 6.89 , and $10.34 \mathrm{MPa}(500,1,000$, and $1,500 \mathrm{psi})$. Two of the specimens failed to satisfy the requirements of ASTM D-2664-80; and one of the eight that satisfied the specification broke prematurely. The results are summarized in Table A-3.

\section{A.2.3 Tensile Strength}

A total of 40 specimens were tested in unconfined diametral compression (the Brazilian test); all the specimens satisfy the ASTM standard for smoothness of the cylindrical surface, but only 13 satisfied the standard for perpendicularity of end surfaces. Many of the specimens did not satisfy the endperpendicularity requirement because their end surfaces were not ground, as was done for the uniaxial and triaxial compression test specimens. The results are tabulated in Table A-4. The average tensile strength for all the specimens is $7.9 \mathrm{MPa}$, with a standard deviation of $5.5 \mathrm{MPa}$; for the 13 specimens that satisfied the ASTM standard for perpendicularity, the mean is $8.5 \mathrm{MPa}$, with a standard deviation of $6.0 \mathrm{MPa}$. As these results show, the ASTM perpendicularity requirement does not have a significant effect on the Brazilian test results. The statistical distribution of the data is presented in Figure A-5.

\section{A.3 REFERENCES FOR APPENDIX A}

Hsiung, S.M., A.H. Chowdhury, W. Blake, M.P. Ahola, and A. Ghosh. 1992. Field Site Investigation: Effect of Mine Seismicity on a Jointed Rock Mass. CNWRA 92-012. San Antonio, TX: Center for Nuclear Waste Regulatory Analyses.

ISRM. 1978a. Suggested methods for determining the strength of rock materials in triaxial compression. International Journal of Rock Mechanics and Mining Sciences \& Geomechanics Abstracts 15(2): 47-51. 
ISRM. 1978b. Suggested methods for determining tensile strength of rock materials. International Journal of Rock Mechanics and Mining Sciences \& Geomechanics Abstracts 15(3): 99-103.

ISRM. 1979. Suggested methods for determining the uniaxial compressive strength and deformability of rock materials. International Journal of Rock Mechanics and Mining Sciences \& Geomechanics Abstracts 16(2): 135-140. 
Table A-1. Unconfined compression test data

\begin{tabular}{|c|c|c|c|c|}
\hline \multirow[b]{2}{*}{ Sample No. } & \multicolumn{2}{|c|}{ Satisfy ASTM Standards? } & \multirow{2}{*}{$\begin{array}{c}\text { Strength } \\
\text { (MPa) }\end{array}$} & \multirow[b]{2}{*}{ Note } \\
\hline & Perpendicularity & Smoothness & & \\
\hline LFM 57-73 U-031 & yes & yes & 220 & \\
\hline LFM 57-73 U-026 & yes & yes & 250 & \\
\hline LFM 57-73 U-023 & no & yes & 111 & \\
\hline LFM 95c2-7 U-014 & yes & yes & 242 & \\
\hline LFM 57-73 U-019b & yes & yes & 90.2 & \\
\hline LFM 57-73 U-017 & yes & yes & 15.0 & $\begin{array}{l}\text { failure along } \\
\text { weakness }\end{array}$ \\
\hline LFM 57-73 U-028 & yes & yes & 86.4 & \\
\hline LFM 57-73 U-041 & yes & yes & 291 & \\
\hline LFM 57-73 U-025b & yes & yes & 133 & \\
\hline LFM 57-73 U-043 & yes & yes & 133 & \\
\hline LFM 95-c2-6 U-001 & no & no & 97.9 & \\
\hline LFM 95-c2-6 U-002 & yes & yes & 73.2 & \\
\hline LFM 95-c2-3A U-010 & yes & no & 307 & \\
\hline LFM 57-73 U-020 & yes & yes & 72.9 & \\
\hline LFM 57-73 U-025a & yes & yes & 202 & \\
\hline LFM 57-73 U-036a & yes & yes & 121 & \\
\hline LFM 57-73 U-037 & yes & yes & 164 & \\
\hline LFM 57-73 U-038 & yes & yes & 169 & \\
\hline LFM 57-73 U-044 & yes & yes & 153 & \\
\hline LFM 57-73 U-052 & no & no & 92.1 & \\
\hline LFM 57-73 U-054 & yes & yes & 78.3 & \\
\hline LFM 57-73 U-056a & yes & yes & 139 & \\
\hline LFM 57-73 U-056b & yes & yes & 169 & \\
\hline LFM 57-73 U-035 & no & yes & 83.5 & \\
\hline LFM 57-73 U-046 & yes & yes & 327 & \\
\hline LFM 57-73 U-049 & yes & yes & 245 & \\
\hline LFM 95-c2-2 U-009 & no & yes & 50.6 & \\
\hline LFM 57-73 U-030 & yes & yes & 214 & \\
\hline LFM 57-73 U-024a & yes & yes & 340 & \\
\hline LFM 57-73 U-024b & yes & yes & 247 & \\
\hline LFM 57-73 U-057 & yes & no & 270 & \\
\hline LFM 57-73 U-039 & yes & yes & 170 & \\
\hline LFM 57-73 U-040 & yes & yes & 175 & \\
\hline LFM 57-73 U-047 & yes & yes & 213 & \\
\hline LFM 57-73 U-048 & yes & yes & 200 & \\
\hline
\end{tabular}


Table A-1. Unconfined compression test data (cont'd)

\begin{tabular}{||l|c|c|c|c||}
\hline & \multicolumn{2}{|c|}{ Satisfy ASTM Standards? } & Strength & \\
\cline { 2 - 4 } \multicolumn{1}{|c|}{ Sample No. } & Perpendicularity & Smoothness & (MPa) & Note \\
\hline \hline LFM 95-c2-6 U-004 & yes & no & 123 & \\
LFM 95-c2-2 U-006 & yes & yes & 227 & \\
LFM 57-73 U-053 & yes & yes & 217 & with strain gage \\
LFM 95-c2-3A U011 & no & no & 304 & with strain gage \\
LFM 57-73 U-045 & yes & yes & 374 & with strain gage \\
LFM 57-73 U-018 & yes & yes & 105 & with strain gage \\
LFM 57-73 U-036b & yes & yes & 215 & with strain gage \\
LFM 95-c2-2 U-007c & yes & yes & 260 & with strain gage \\
LFM 95-c2-2 U-007b & yes & yes & 214 & with strain gage \\
LFM 95-c2-2 U-008a & yes & yes & 151 & with strain gage \\
LFM 95-c2-2 U-008b & yes & yes & 126 & with strain gage \\
LFM 57-73 U-027 & yes & yes & 87.9 & with strain gage \\
\hline
\end{tabular}


Table A-2. Unconfined compression test with strain gauges

\begin{tabular}{|c|c|c|c|c|}
\hline \multirow{2}{*}{ Sample No. } & Strength & Young's Modulus & $\begin{array}{c}\text { Poisson's } \\
\text { Ratio }\end{array}$ & Note \\
\cline { 2 - 5 } & $(\mathbf{M P a})$ & $\left(\mathbf{1 0}^{\mathbf{4}} \mathbf{M P a}\right)$ & 0.20 & \\
\hline \hline LFM 95-c2-2 U-007b & 214 & 5.1 & 0.20 & \\
LFM 95-c2-2 U-007c & 260 & 6.0 & 0.15 & \\
LFM 95-c2-2 U-008a & 151 & 5.2 & 0.21 & \\
LFM 95-c2-2 U-008b & 126 & 4.7 & 0.18 & \\
LFM 95-c2-3A U-011 & 304 & 7.6 & 0.13 & \\
LFM 57-73 U-018 & 105 & 1.2 & 0.11 & \\
LFM 57-73 U-027 & 88 & 4.8 & 0.17 & \\
LFM 95-c2-2 U-036b & 215 & 6.7 & 0.15 & \\
LFM 95-c2-2 U-045 & 374 & 8.1 & 0.25 & \\
LFM 95-c2-2 U-053 & 217 & 5.3 & \\
\hline
\end{tabular}

Table A-3. Triaxial compression test data

\begin{tabular}{|c|c|c|c|c|c|}
\hline \multirow[b]{2}{*}{ Sample No. } & \multicolumn{2}{|c|}{ Satisfy ASTM Standards? } & \multirow{2}{*}{$\begin{array}{c}\sigma_{\mathbf{3}} \\
(\mathbf{M P a})\end{array}$} & \multirow{2}{*}{$\begin{array}{c}\sigma_{1} \\
(\mathbf{M P a})\end{array}$} & \multirow[b]{2}{*}{ Note } \\
\hline & Perpendicularity & Smoothness & & & \\
\hline LFM 95-c2-6 U-005 & yes & yes & 3.45 & 297 & \\
\hline LFM 95-c1-5 U-012 & yes & no & 3.45 & 179 & \\
\hline LFM 95-c1-2 U-15 & yes & yes & 3.45 & 107 & along weakness \\
\hline LFM 95-c2-2 U-007d & yes & yes & 6.90 & 268 & \\
\hline LFM 95-c1-5 U-013 & no & no & 6.90 & 234 & \\
\hline LFM 57-73 U-055 & yes & yes & 6.90 & 75.6 & \\
\hline LFM 57-73 U-016 & yes & yes & 10.3 & 153 & \\
\hline LFM 57-73 U-022 & yes & yes & & & broken \\
\hline LFM 57-73 U-033 & yes & yes & 10.3 & 273 & \\
\hline LFM 57-73 U-050 & yes & yes & 10.3 & 250 & \\
\hline
\end{tabular}


Table A-4. Indirect tensile strength (Brazilian test) data

\begin{tabular}{|c|c|c|c|c|}
\hline \multirow[b]{2}{*}{ Sample No. } & \multicolumn{2}{|c|}{ Satisfy ASTM Standards? } & \multirow{2}{*}{$\begin{array}{c}\text { Tensile } \\
\text { Strength } \\
\text { (MPa) }\end{array}$} & \multirow[b]{2}{*}{ Note } \\
\hline & Perpendicularity & Smoothness & & \\
\hline LFM 95-c2-6 B-001 & no & yes & 12.1 & VersaTester \\
\hline LFM 95-c1-4 B-002 & yes & yes & 4.1 & VersaTester \\
\hline LFM 95-c1-4 B-003b & no & yes & 6.8 & VersaTester \\
\hline LFM 95-c2-6 B-005 & no & yes & 6.6 & VersaTester \\
\hline LFM 95-c2-6 B-006a & no & yes & 1.7 & VersaTester \\
\hline LFM 95-c2-6 B-007 & no & yes & 1.5 & VersaTester \\
\hline LFM 95-c2-6 B-009 & no & yes & 1.5 & VersaTester \\
\hline LFM 95-c2-6 B-010 & no & yes & 1.4 & VersaTester \\
\hline LFM 95-c2-2 B-014c & yes & yes & 7.1 & VersaTester \\
\hline LFM 95-1-5 B-021a & yes & yes & 1.7 & VersaTester \\
\hline LFM 95-c1-5 B-022 & no & yes & 1.7 & VersaTester \\
\hline LFM 95-c2-7 B-024 & no & yes & 1.7 & VersaTester \\
\hline LFM 95-c2-2 B028 & no & yes & 1.6 & VersaTester \\
\hline LFM 57-73 B-054 & no & yes & 2.2 & VersaTester \\
\hline LFM 57-73 B-055 & no & yes & 2.3 & VersaTester \\
\hline LFM 57-73 B-062 & yes & yes & 1.9 & VersaTester \\
\hline LFM 57-73 B-063a & yes & yes & 2.5 & VersaTester \\
\hline LFM 95-c2-6 B-011 & no & yes & 14.0 & SBEL \\
\hline LFM 95-c2-2 B-029 & yes & yes & 15.2 & SBEL \\
\hline LFM 95-c-4 B-031 & no & yes & 9.8 & SBEL \\
\hline LFM 57-73 B-032 & no & yes & 14.0 & SBEL \\
\hline LFM 57-73 B-035 & no & yes & 7.0 & SBEL \\
\hline LFM 57-73 B-0378 & no & yes & 6.4 & SBEL \\
\hline LFM 57-73 B-040a & no & yes & 11.5 & SBEL \\
\hline LFM 57-73 B-042 & no & yes & 10.1 & SBEL \\
\hline LFM 57-73 B-045 & yes & yes & 11.4 & SBEL \\
\hline LFM 57-73 B-046a & no & yes & 17.5 & SBEL \\
\hline LFM 57-73 B-047 & yes & yes & 8.9 & SBEL \\
\hline LFM 57-73 B-048 & no & yes & 10.6 & SBEL \\
\hline LFM 57-73 B-050 & no & yes & 7.9 & SBEL \\
\hline LFM 57-73 B-051 & no & yes & 3.7 & SBEL \\
\hline LFM 57-73 B-052 & no & yes & 17.3 & SBEL \\
\hline LFM 57-73 B-056 & no & yes & 14.0 & SBEL \\
\hline LFM 57-73 B-057 & yes & yes & 8.5 & SBEL \\
\hline LFM 57-73 B-059a & yes & yes & 20.6 & SBEL \\
\hline
\end{tabular}


Table A-4. Indirect tensile strength (Brazilian test) data (cont'd)

\begin{tabular}{||c|c|c|c|c||}
\hline \multirow{2}{*}{ Sample No. } & \multicolumn{2}{|c|}{ Satisfy ASTM Standards? } & $\begin{array}{c}\text { Tensile } \\
\text { Strength } \\
\text { (MPa) }\end{array}$ & Note \\
\cline { 2 - 4 } & Perpendicularity & Smoothness & 16.9 & SBEL \\
\hline \hline LFM 57-73 B-060b & yes & yes & 5.8 & SBEL \\
LFM 57-73 B-064b & yes & yes & 6.2 & SBEL \\
LFM 57-73 B-065 & yes & yes & 6.1 & SBEL \\
LFM 57-73 B-066 & no & yes & 15.2 & SBEL \\
LFM 57-73 B-067a & no & yes & \\
\hline
\end{tabular}



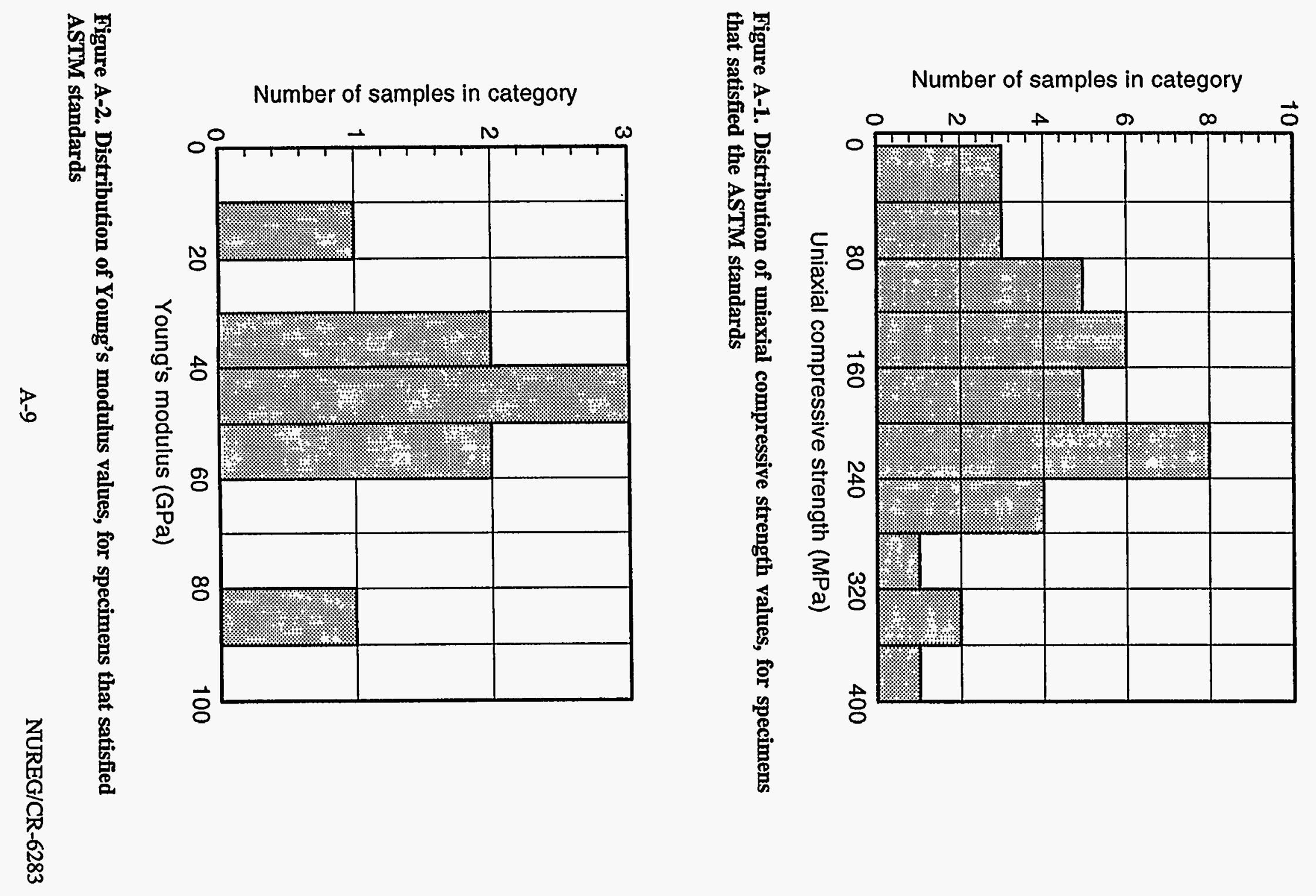


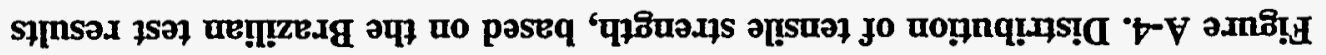

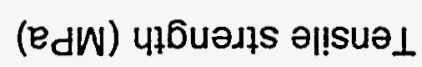

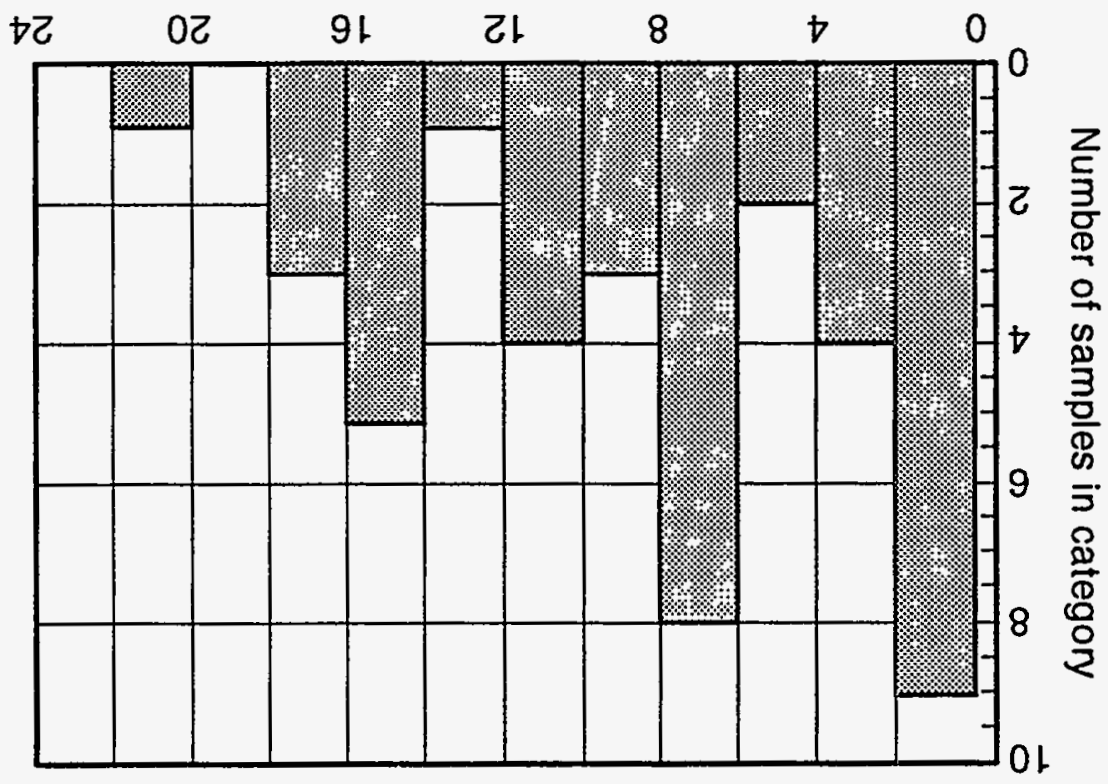

sp.xepueq̧ WLSV

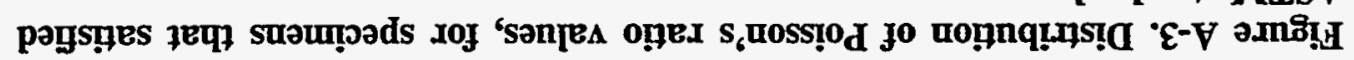

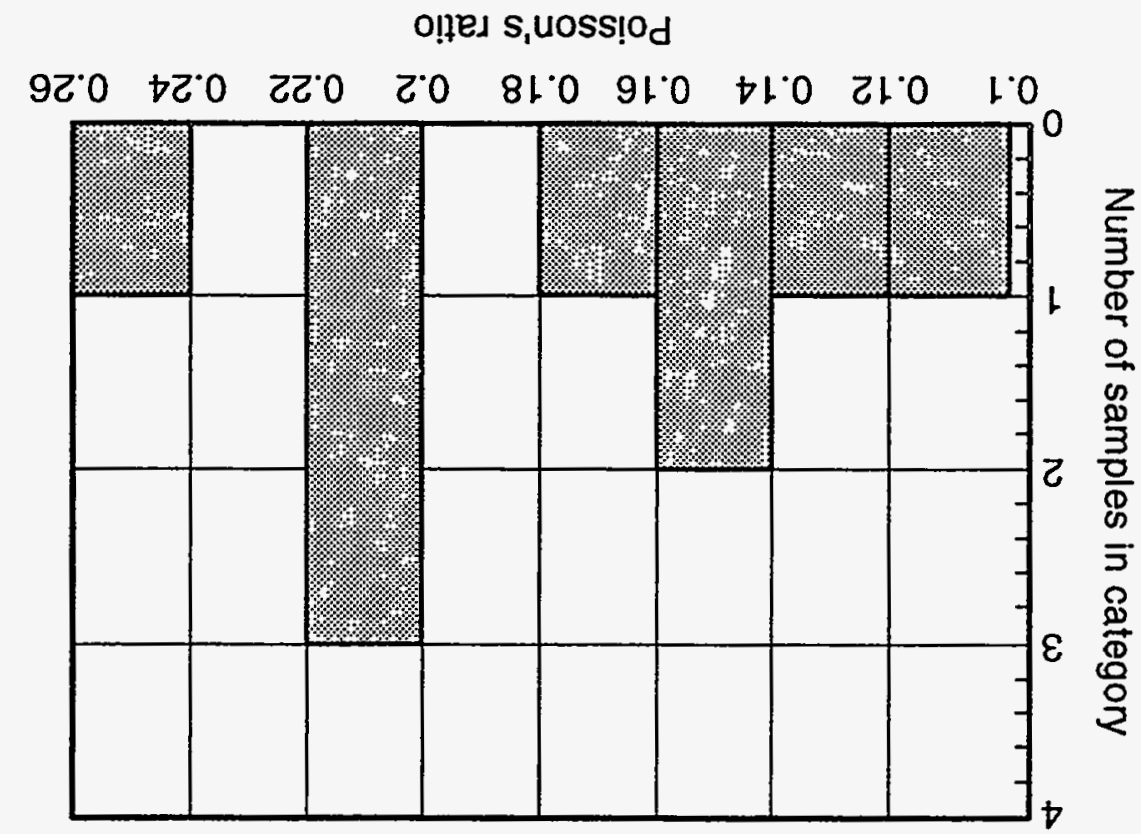




\section{APPENDIX B}

ROCK QUALITY LOG FOR THE GROUNDWATER RESPONSE BOREHOLE AND TYPICAL JOINT SURFACE PROPERTIES 


\section{B. ROCK QUALITY LOG FOR THE GROUNDWATER RESPONSE BOREHOLE AND TYPICAL JOINT SURFACE PROPERTIES}

\section{B.1 ROCK QUALITY LOGS}

A rock quality logging of the groundwater response borehole (the $360-\mathrm{m}$ long inclined borehole drilled from the 5,700-level station of the mine) was conducted. The log shows the length of pieces of rock cores recovered from the borehole; it can be interpreted to obtain information on rock quality designation (RQD), fracture density, and the location of fractures in the borehole. Four sections of the log are shown in Figures B-1 through B-4, each of which covers about $3.35 \mathrm{~m}$ (11 ft) of the borehole.

Figure B-1 shows the 152-155 m (498-507 ft) depth range of the borehole. The value of RQD for this range is 81 (i.e., 81 percent of the total length of cores consists of core pieces $10 \mathrm{~cm}$ or longer). Five fractures inclined to the borehole axis were identified in this section; in addition, the distribution of length of core pieces suggests that this section of the borehole is intersected by several other fractures, so closely spaced that they caused the core to break up into very small pieces. Six such fracture zones, ranging in thickness from 0.03 to $0.1 \mathrm{~m}$, can be identified in the log.

Figures B-2, B-3, and B-4 cover depth ranges of about 221-224 m (725-734 ft), 278-282 m (913-925 ft), and 293-295 m (960-969 ft), respectively, which include the depth of the Zone 3, Zone 2, and Zone 1 piezometers, respectively (see column 2 of Table 4-1). The values of RQD for these three borehole sections are 11,28 , and 31 , respectively. As the three logs show, the borehole is intersected by several closely spaced fractures within these zones, which cause the rock to be fragmented.

All the cores were photographed. Four of the photographs corresponding to the logs in Figures B-1 through B-4 are given in Figures B-5 through B-8, respectively. The rest will be archived at the CNWRA, along with the rock quality logs.

The information contained in these logs (only four of which are shown) may be used to select a numerical modeling approach for the rock mass; determining if fractures should be modeled individually, as a number of isolated fracture clusters, or as one continuous cluster (in which case the rock mass would be considered as a continuous porous medium).

\section{B.2 JONT ROUGHNESS PROFILES}

Ten fracture surfaces encountered in the groundwater response borehole were scanned to obtain a sample of the fracture surface roughness. This information can be used to calculate values of Joint Roughness Coefficient (JRC) for the fractures. Four of the profiles are given in Figures B-9 through B-12. The rest will be archived at the CNWRA.

\section{B.3 JOINT SURFACE FRICTION ANGLE}

Tilt tests (cf. Barton and Choubey, 1977) were conducted to obtain values of friction angle for selected joint surfaces. A total of five specimens were tested. Each specimen was tested twice; the values of tilt angles obtained are listed in Table B-1. 
Table B-1. Values of friction angle for joint surfaces, based on the tilt test

\begin{tabular}{|c|c|c|}
\hline \multirow{2}{*}{ Mass of sliding block (g) } & \multicolumn{2}{|c|}{ Tilt angle at which sliding occurred } \\
\cline { 2 - 3 } & Test 1 & Test 2 \\
\hline \hline 65.1 & $58^{\circ}$ & $55^{\circ}$ \\
\hline 45.2 & $54^{\circ}$ & $51^{\circ}$ \\
\hline 92.5 & $58^{\circ}$ & $59^{\circ}$ \\
\hline 57.3 & $54^{\circ}$ & $61^{\circ}$ \\
\hline 75.0 & $45^{\circ}$ & $58^{\circ}$ \\
\hline
\end{tabular}

\section{B.4 JOINT COMPRESSIVE STRENGTH}

Although the joint compressive strength (JCS) for the joints can be estimated using the Schmidt Hammer Test (cf. Barton and Choubey, 1977), this test requires larger-size specimens than were available. Therefore, it is suggested that the value of JCS be estimated using the values of unconfined compressive strength reported in Appendix A.

\section{B.5 REFERENCES FOR APPENDIX B}

Barton, N. and V. Chouby. 1977. The shear strength of rock joints in theory and practice. Rock Mechanics 10: 1-54. 


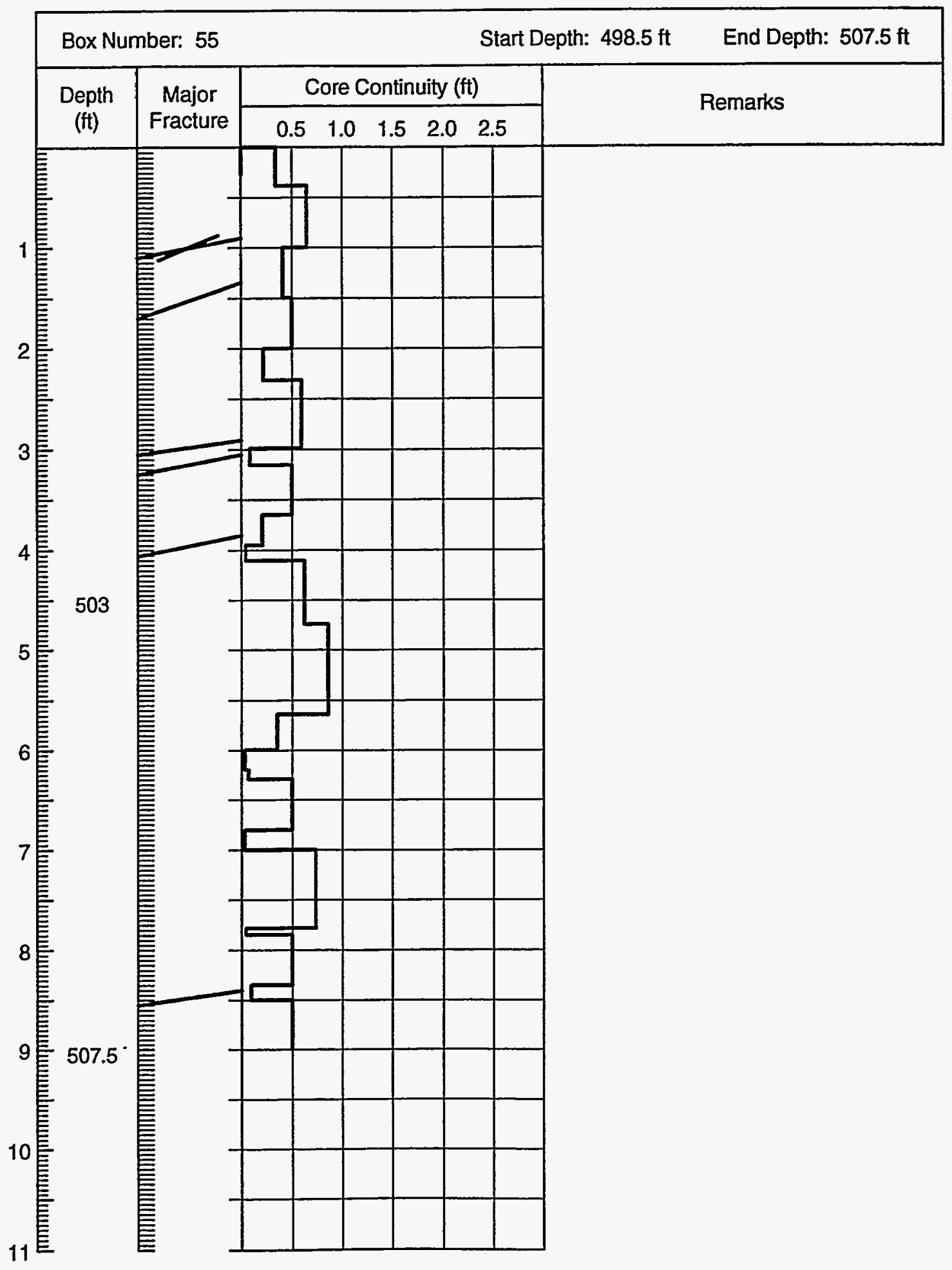

Figure B-1. Rock quality log for groundwater response borehole: $152-155 \mathrm{~m}$ (498.5-507.5 ft) 


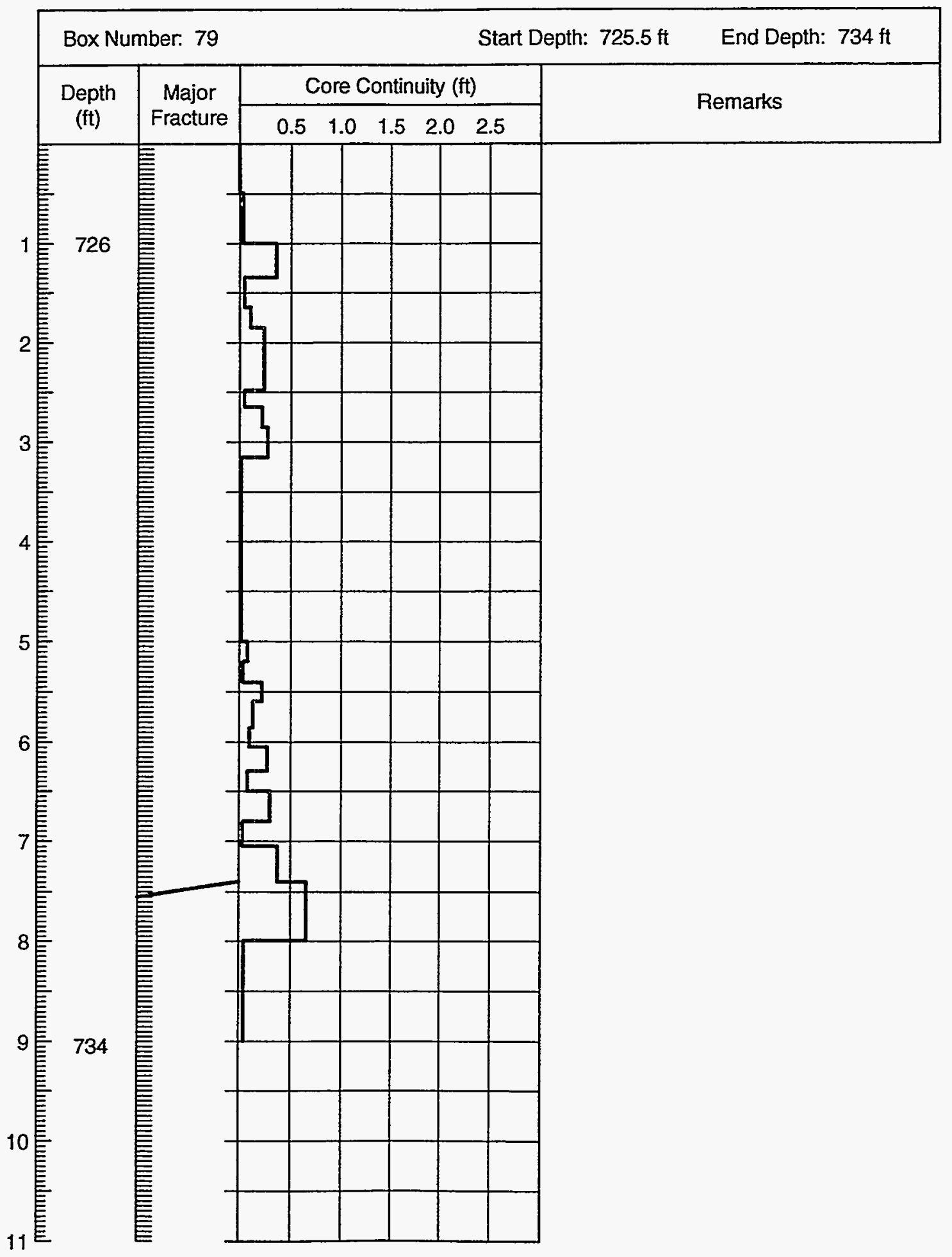

Figure B-2. Rock quality log for groundwater response borehole: 221-224 m (725.5-734 ft) 


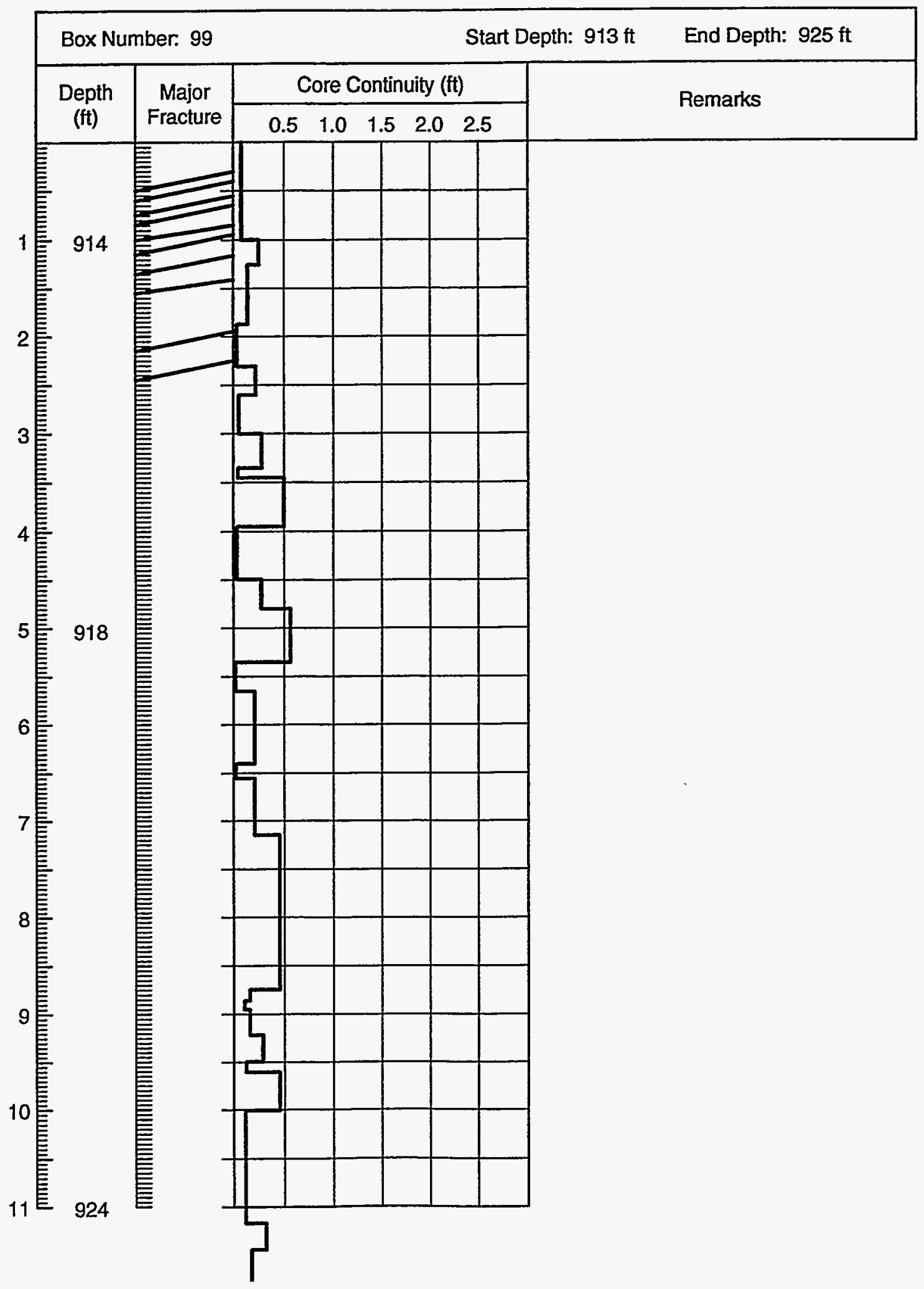

Figure B-3. Rock quality log for groundwater response borehole: $278-282 \mathrm{~m}$ (913-925 ft) 


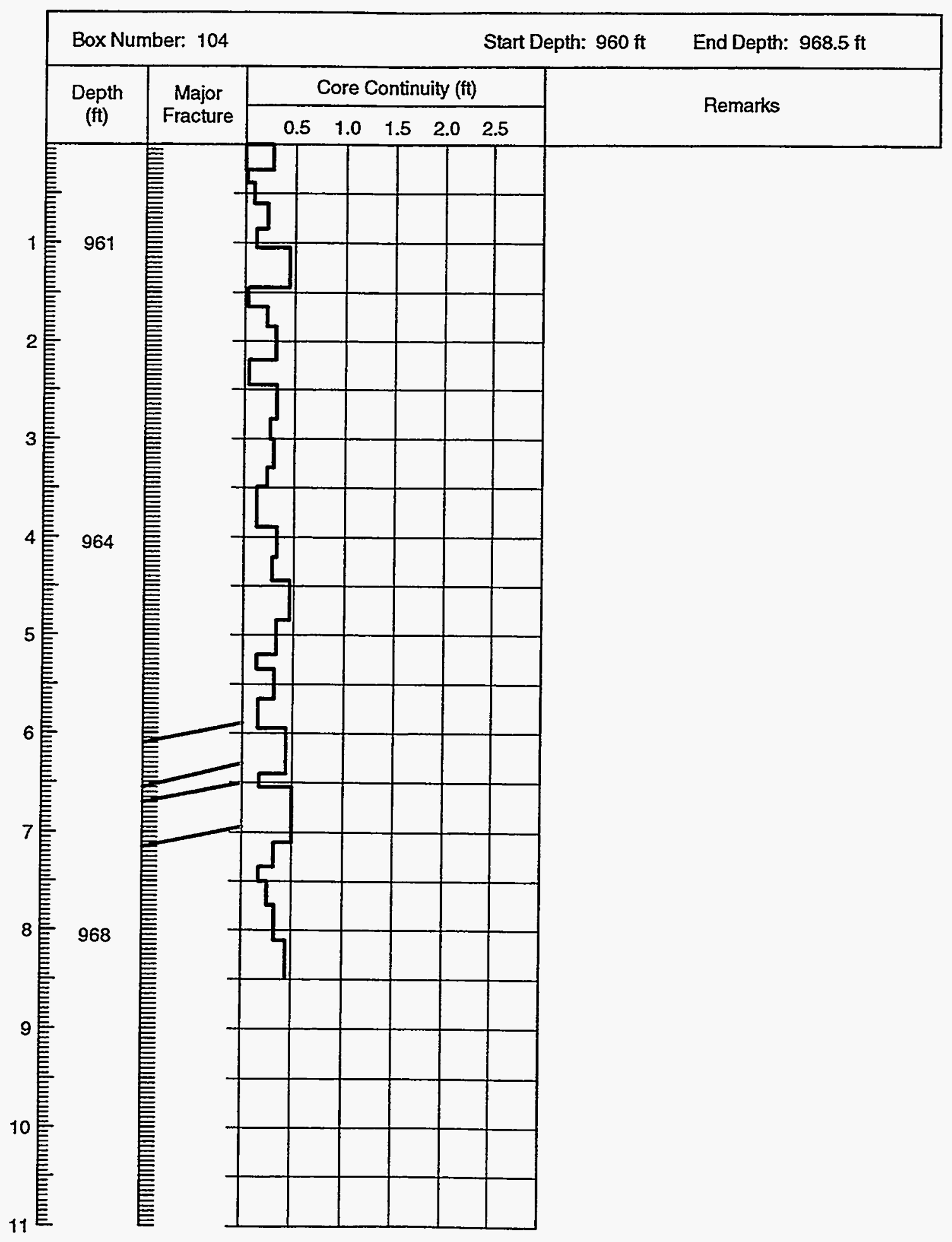

Figure B-4. Rock quality log for groundwater response borehole: 293-295 m (960-968.5 ft) 


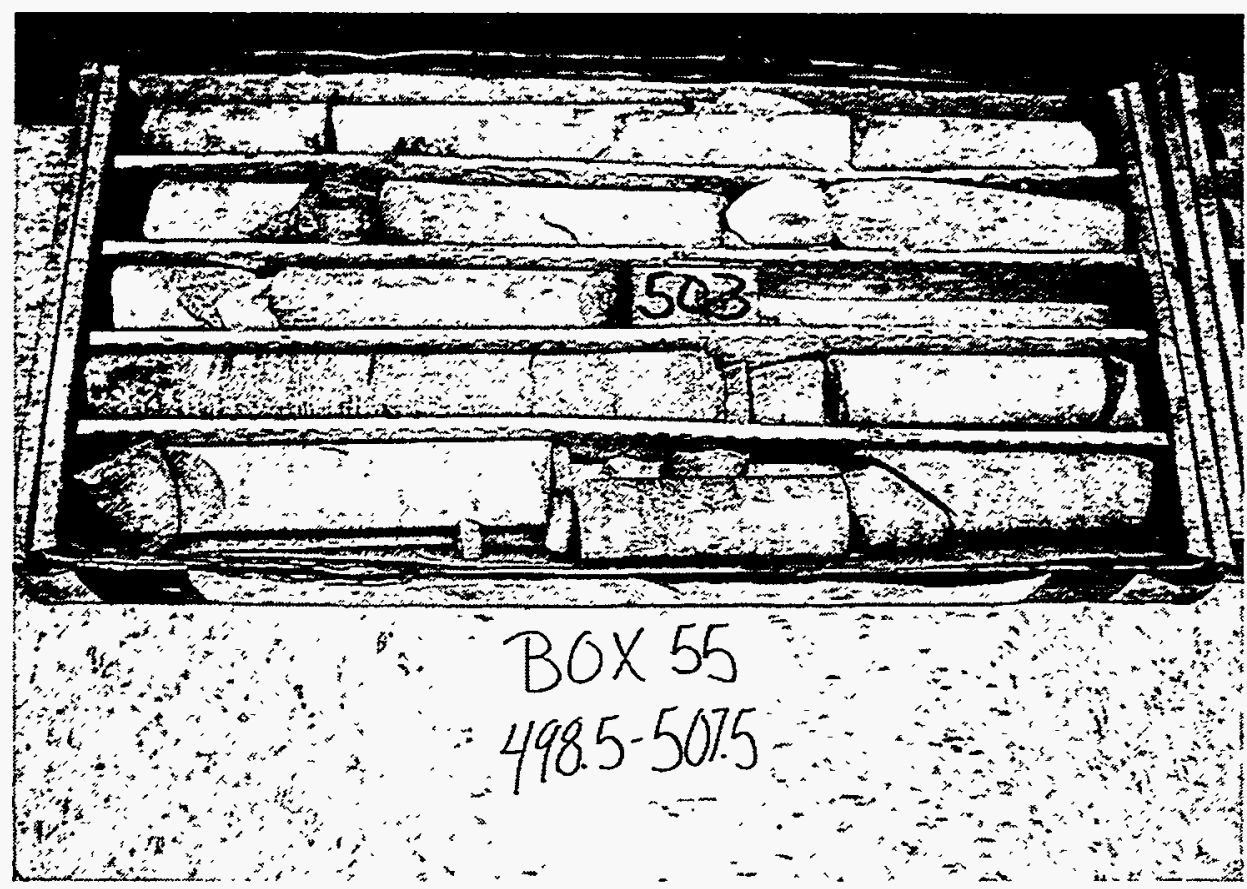

Figure B-5. Photograph of core box number 55: groundwater response borehole: $152-155 \mathrm{~m}$ (498.5-507.5 ft)

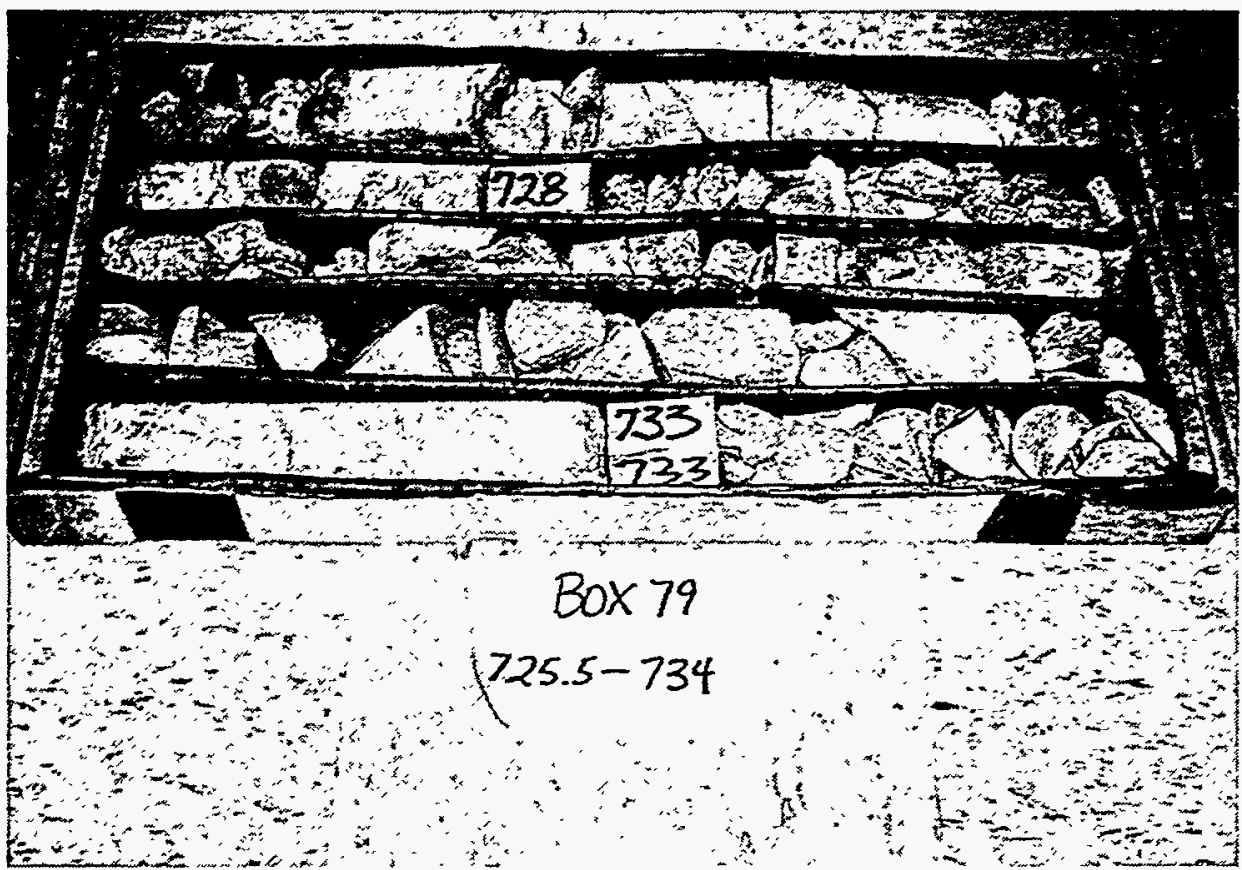

Figure B-6. Photograph of core box number 79: groundwater response borehole: $221-224 \mathrm{~m}$ (725.5-734 ft) 


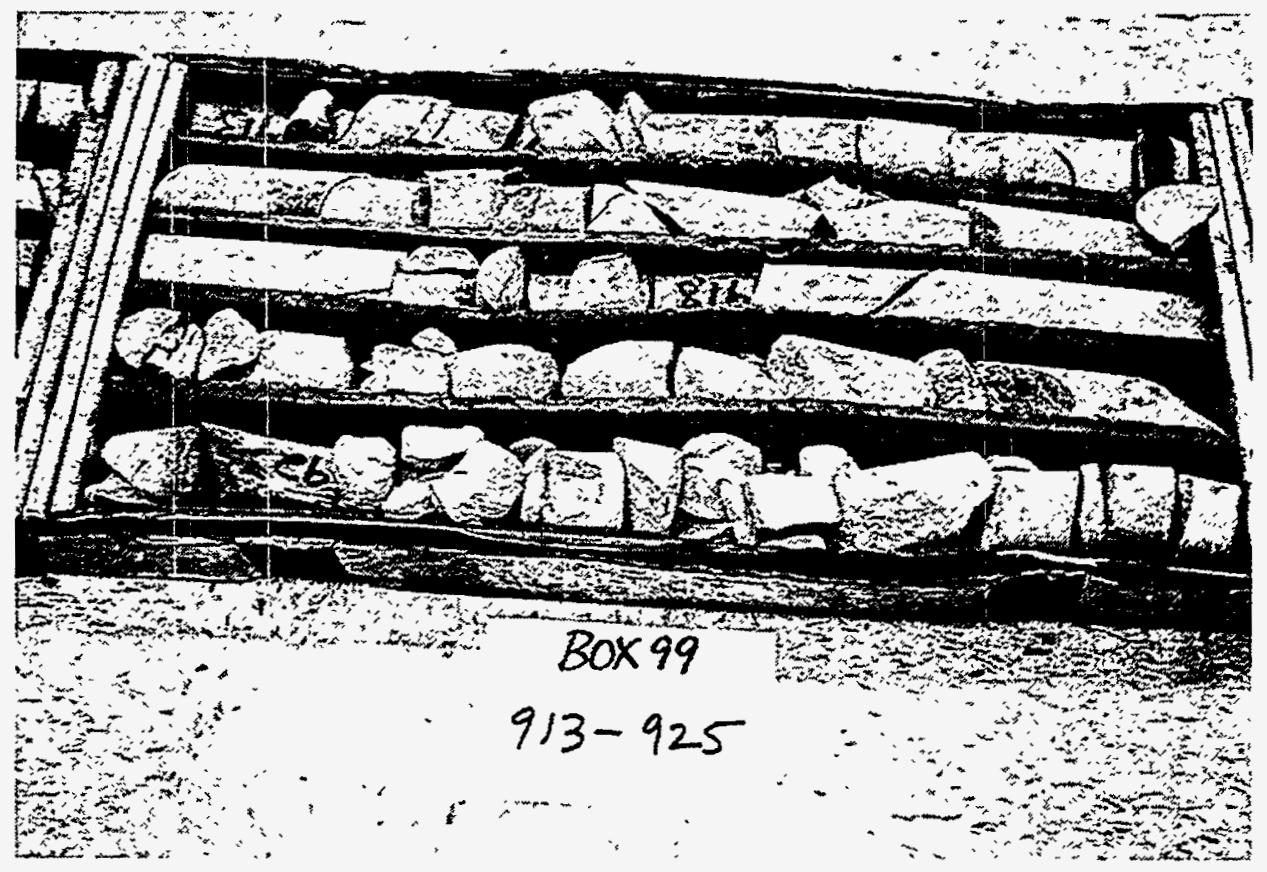

Figure B-7. Photograph of core box number 99: groundwater response borehole: $278-282 \mathrm{~m}(913-925 \mathrm{ft})$

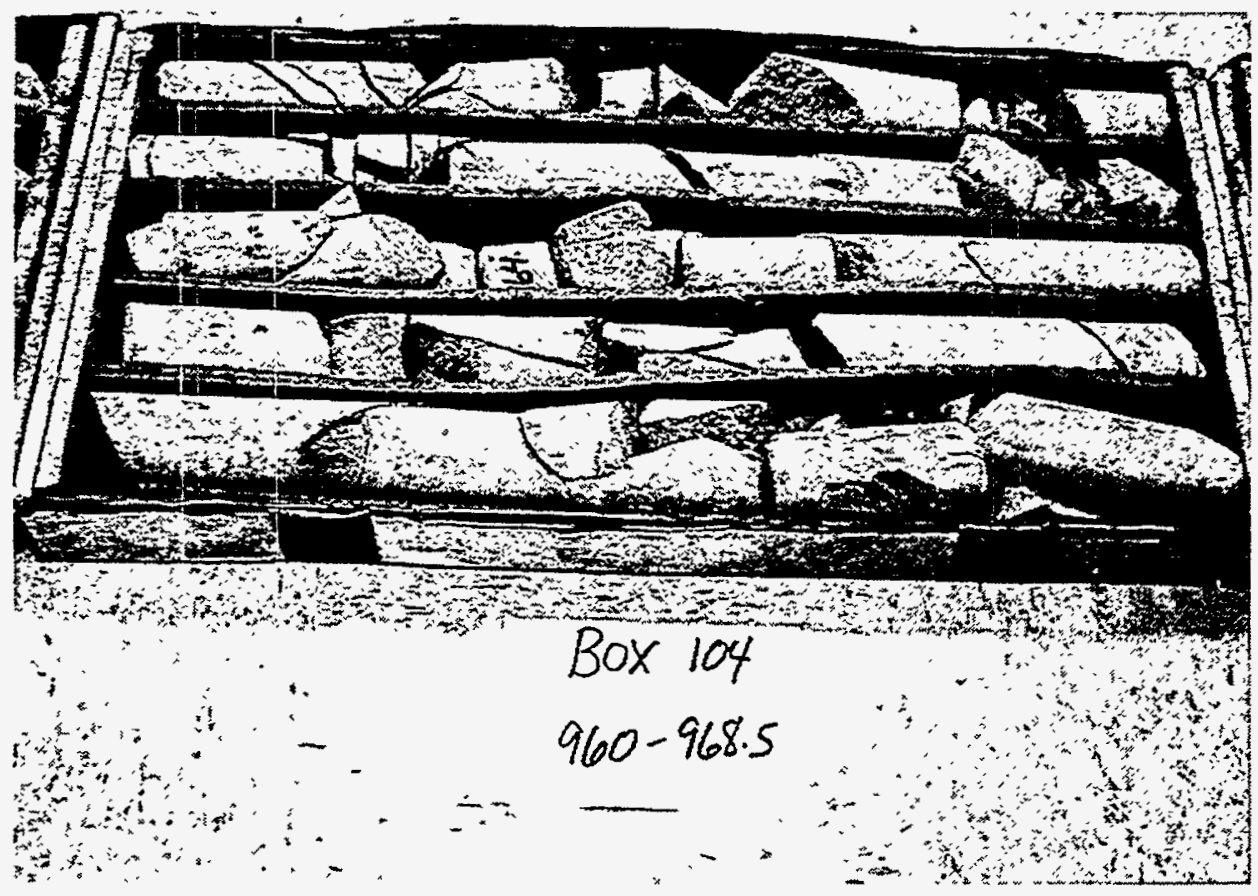

Figure B-8. Photograph of core box number 104: groundwater response borehole: 293-295 $\mathrm{m}$ (960-968.5 ft) 

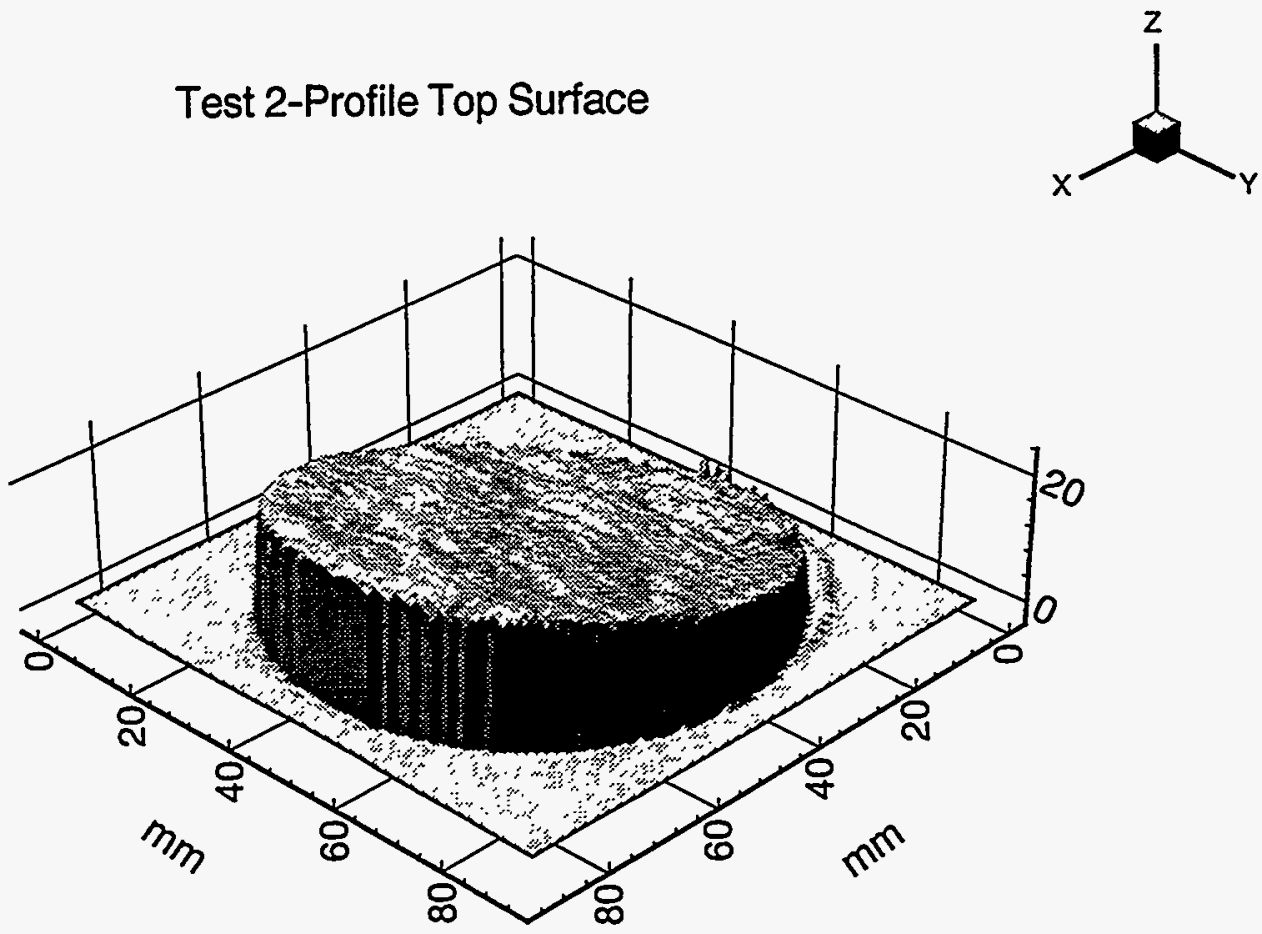

Figure B-9. A typical fracture surface profile from the groundwater response borehole: Top surface of core specimen from depth $12 \mathrm{~m}$ (38 ft)

Test 2-Profile Bottom Surface<smiles>[X]C1=CC([X])=C1[Z]</smiles>

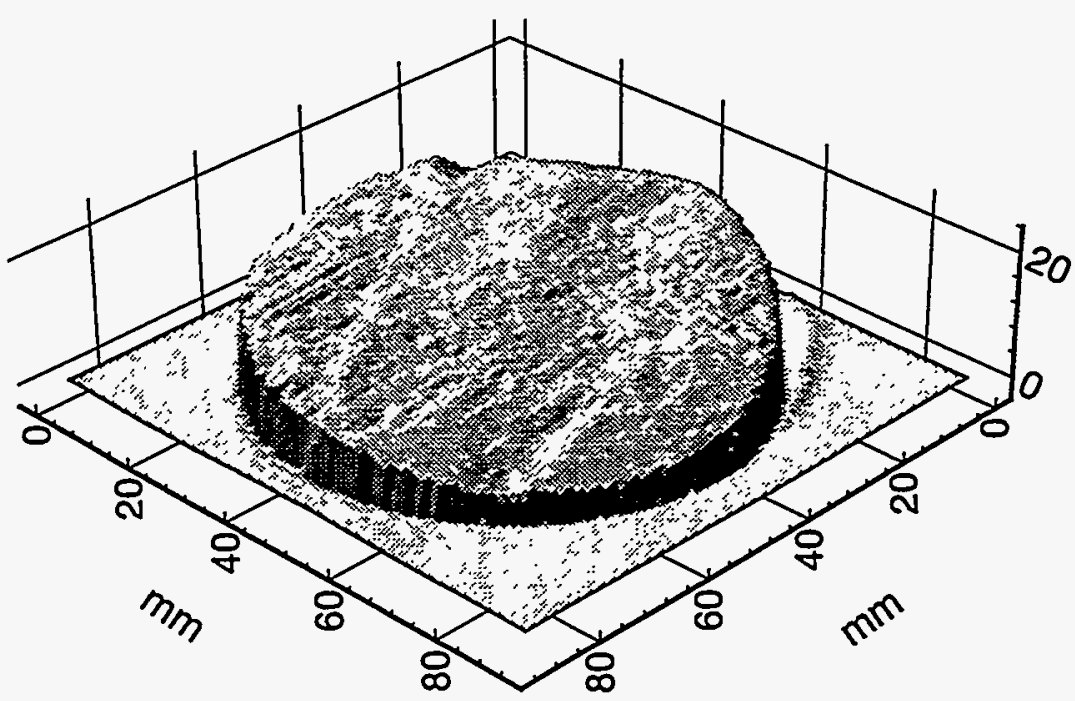

Figure B-10. A typical fracture surface profile from the groundwater response borehole: Bottom surface of core specimen from depth $12 \mathrm{~m}$ (38 ft) 

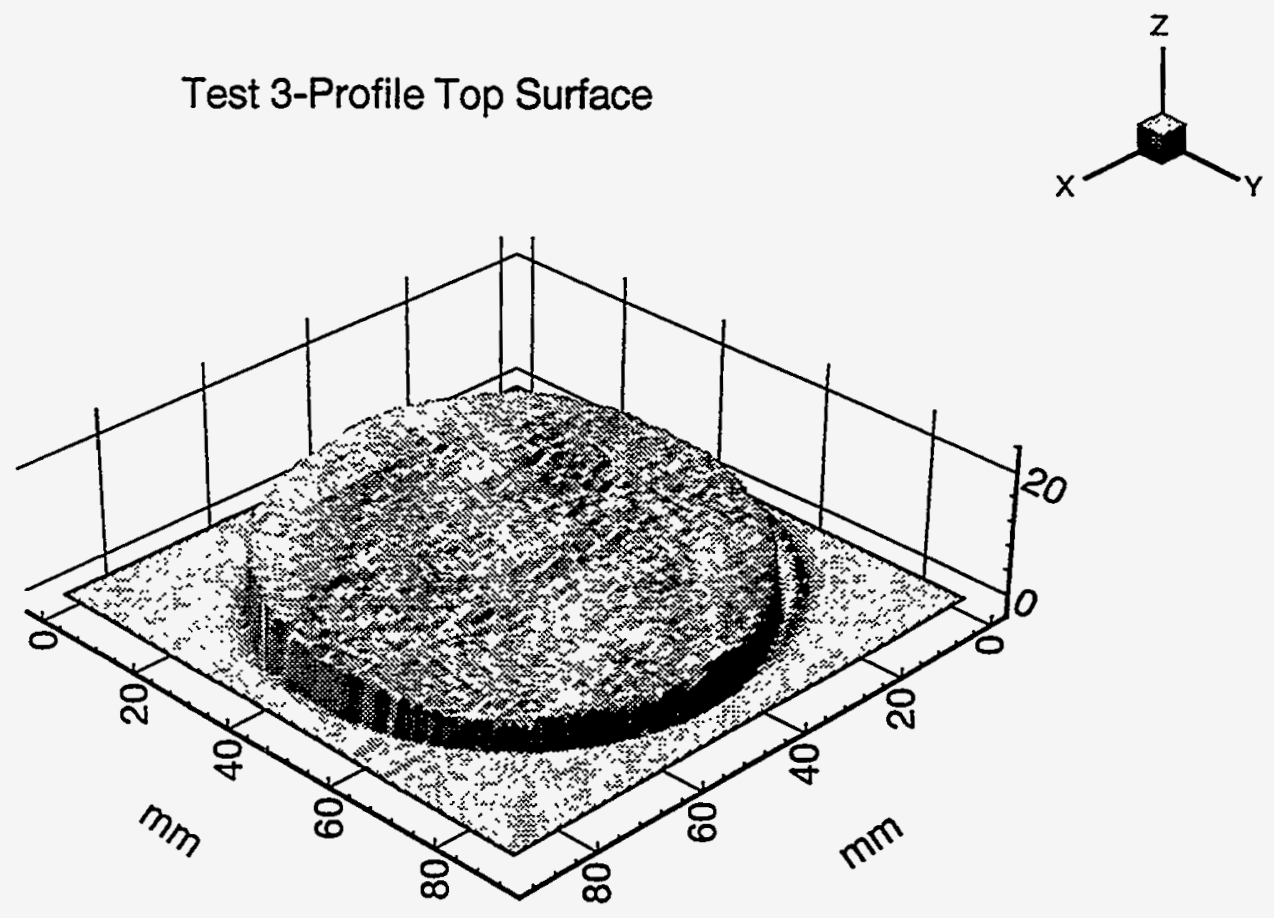

Figure B-11. A typical fracture surface profile from the groundwater response borehole: Top surface of specimen from depth $14 \mathrm{~m}$ (47 ft)

Test 3-Profile Bottom Surface
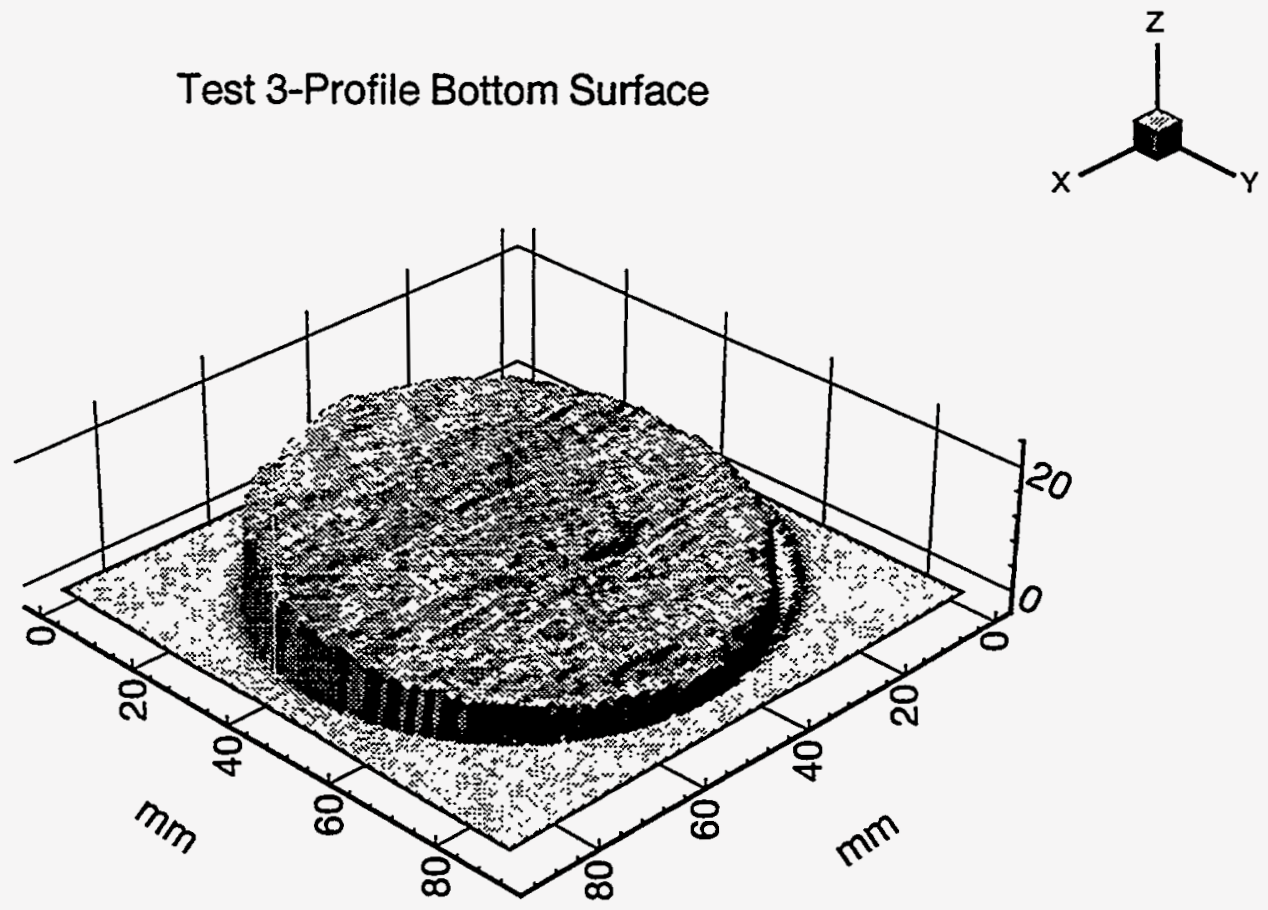

Figure B-12. A typical fracture surface profile from the groundwater response borehole: Bottom surface of specimen from depth $14 \mathrm{~m} \mathrm{(47} \mathrm{ft)}$ 


\section{APPENDIX C}

\section{GROUNDWATER PRESSURE HISTORY PLOTS}




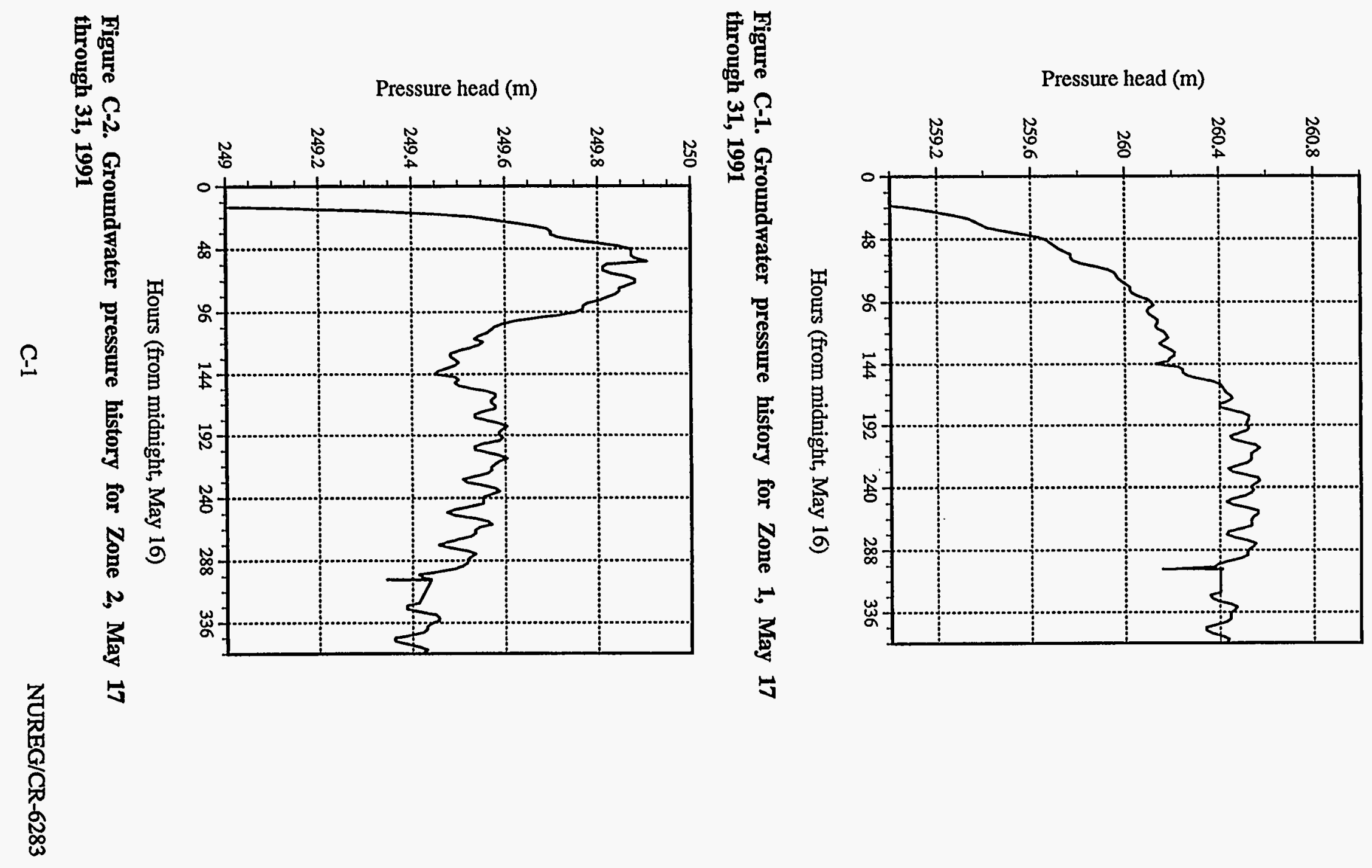




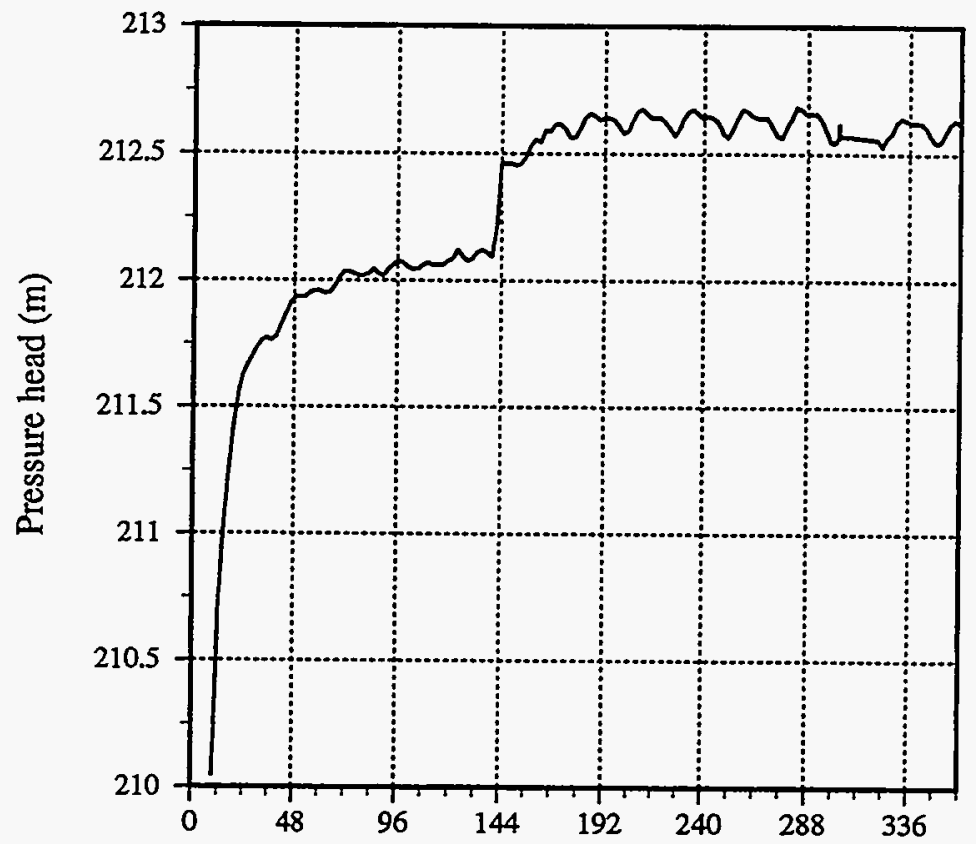

Hours (from midnight, May 16)

Figure C-3. Groundwater pressure history for Zone 3, May 17 through 31, 1991

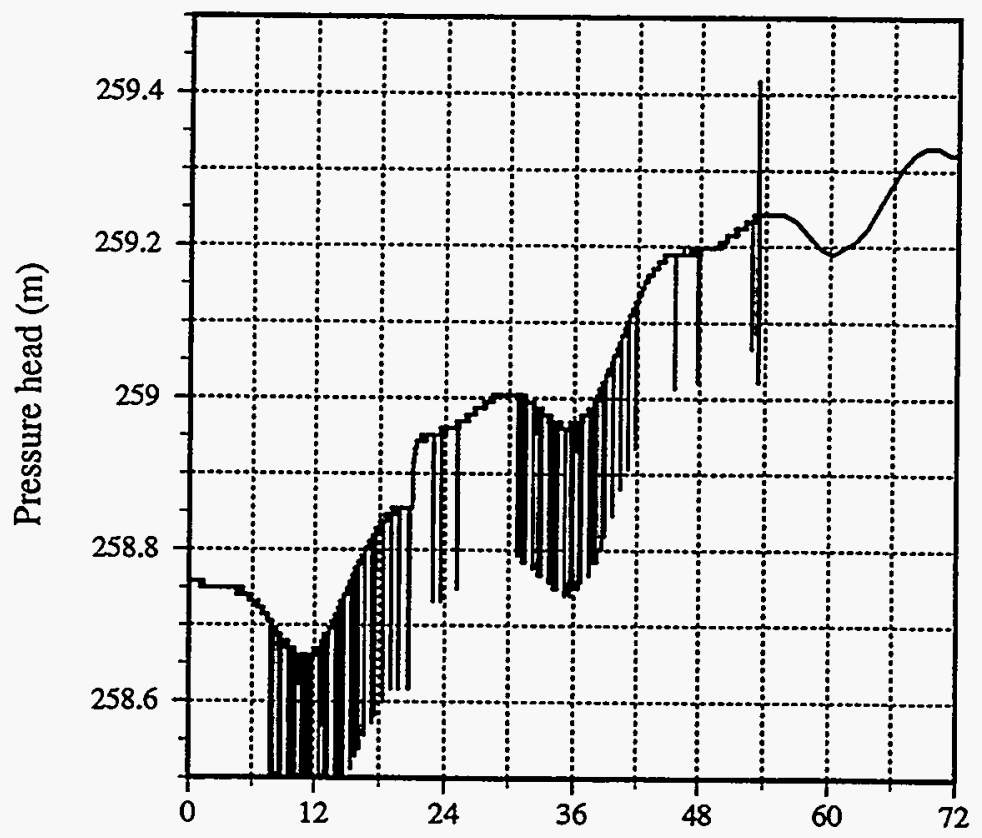

Hours (from midnight, June 11)

Figure C-4. Groundwater pressure history for Zone 1, June 12 through 16, 1991 


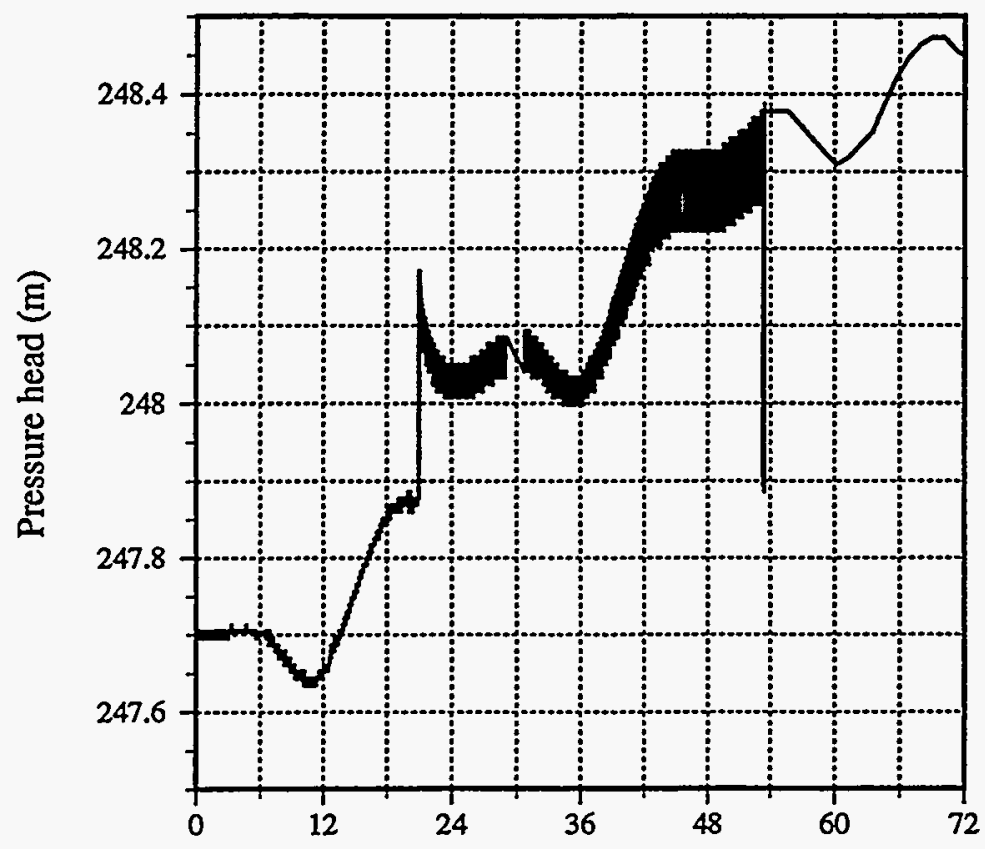

Hours (from midnight, June 11)

Figure C-5. Groundwater pressure history for Zone 2, June 12 through 16, 1991

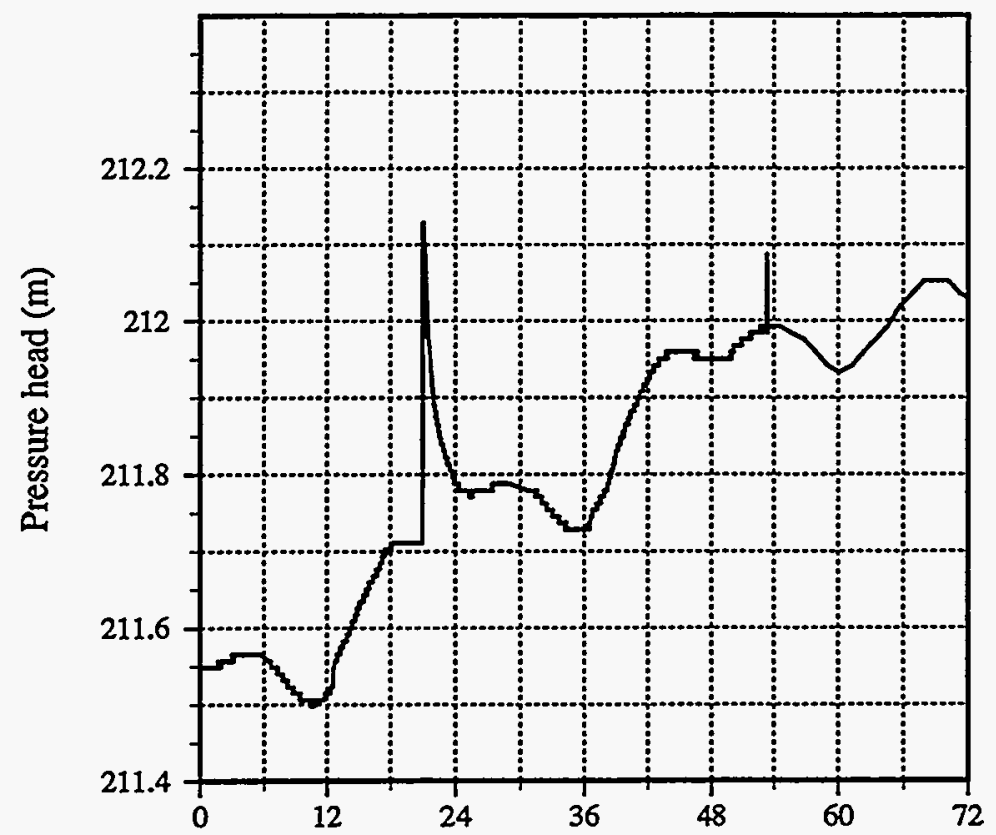

Hours (from midnight, June 11)

Figure C-6. Groundwater pressure history for Zone 3, June 12 through 16, 1991 

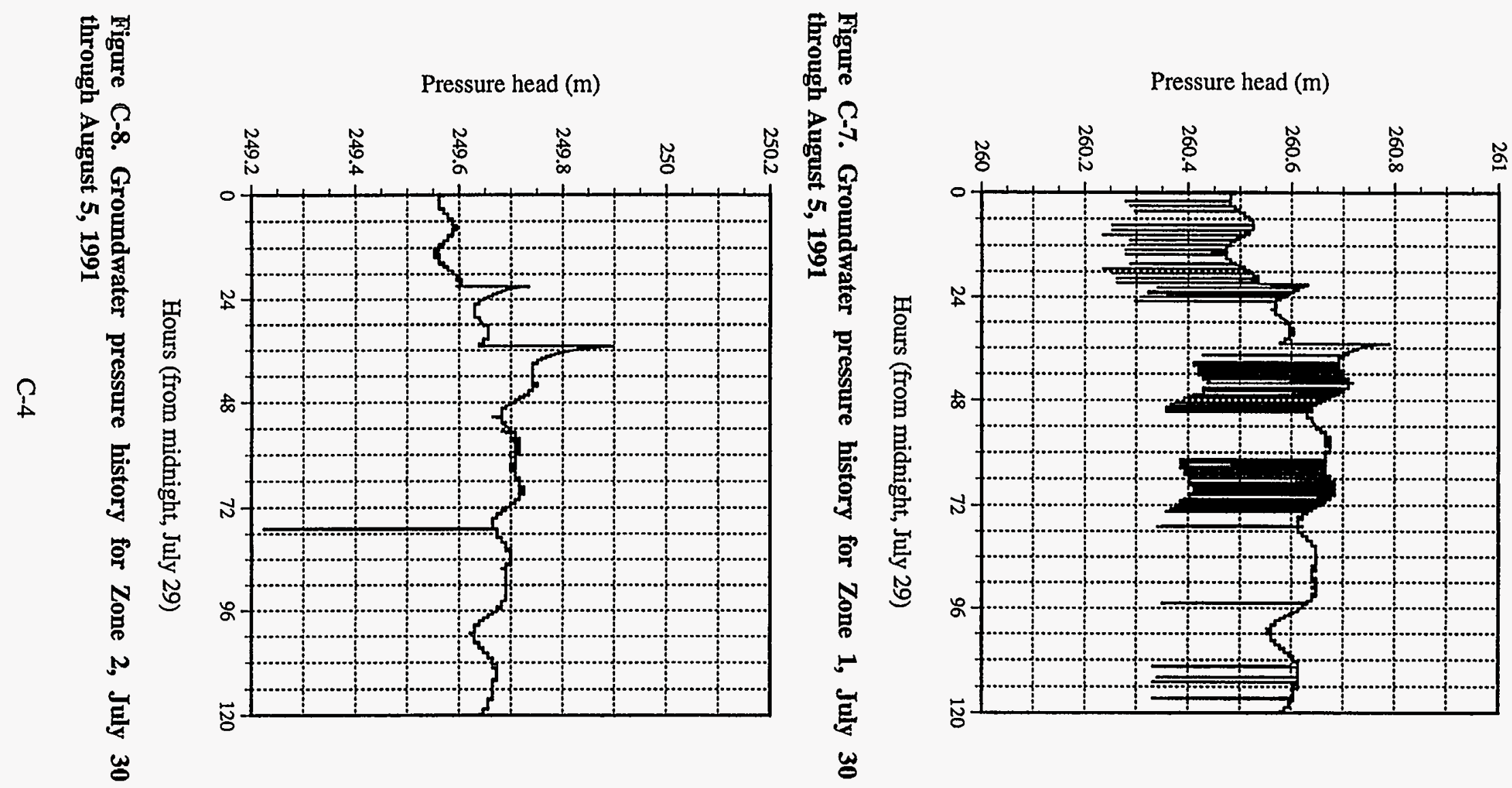


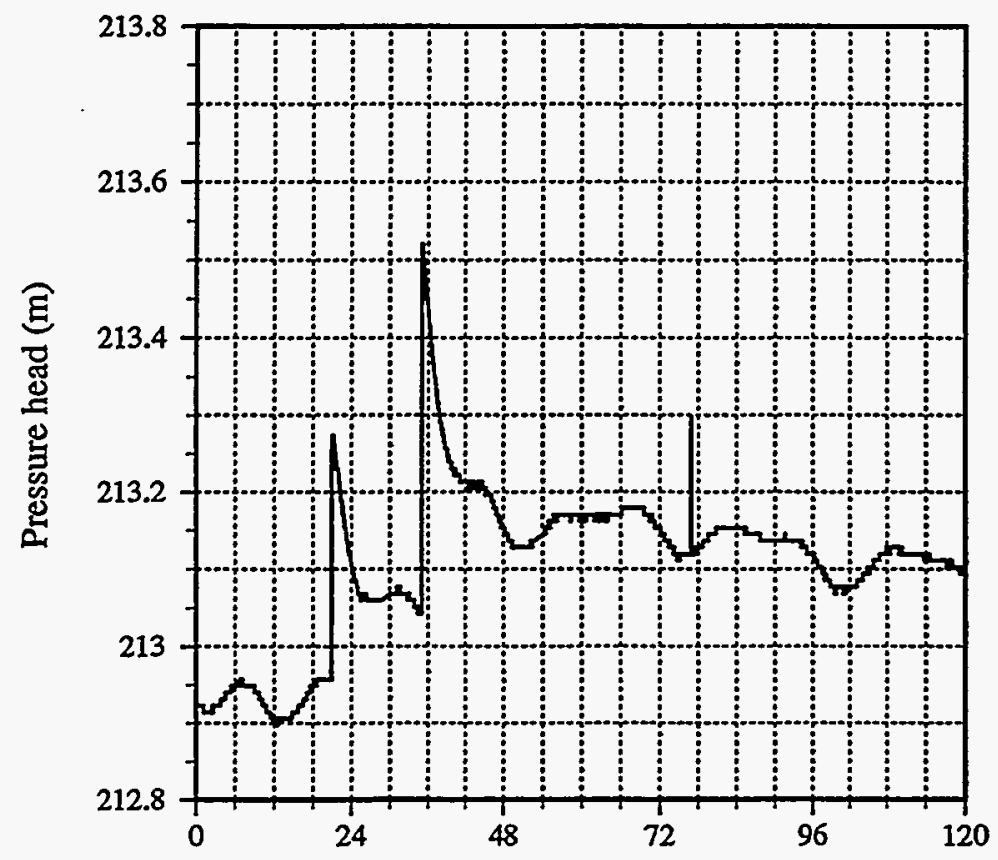

Hours (from midnight, July 29)

Figure C-9. Groundwater pressure history for Zone 3, July 30 through August 5, 1991

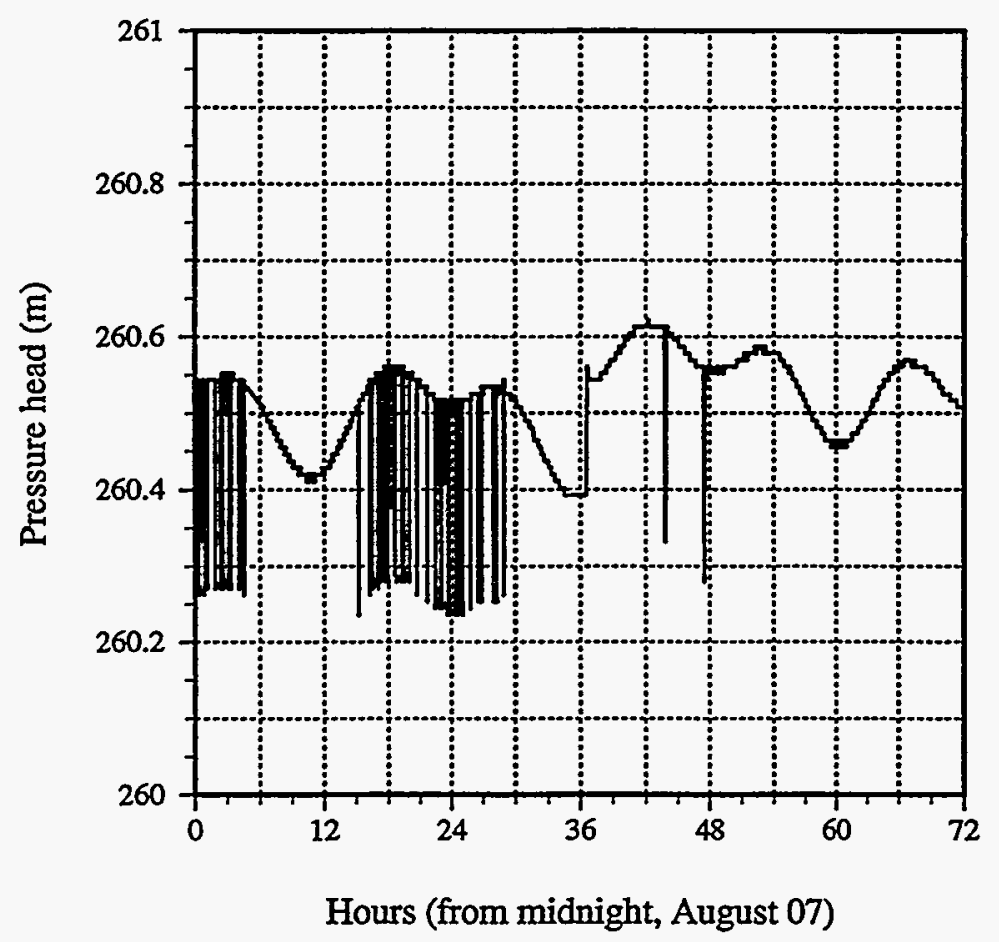

Figure C-10. Groundwater pressure history for Zone 1, August 8 through 10, 1991 


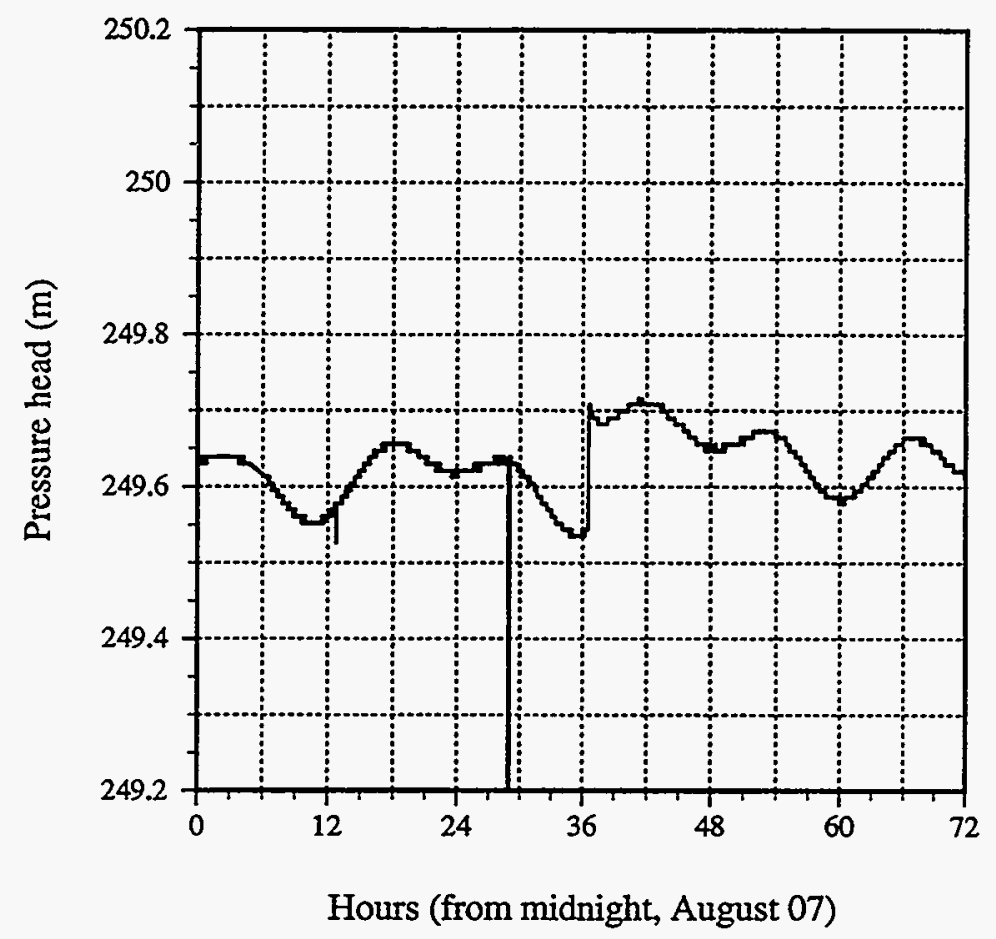

Figure C-11. Groundwater pressure history for Zone 2, August 8 through 10, 1991

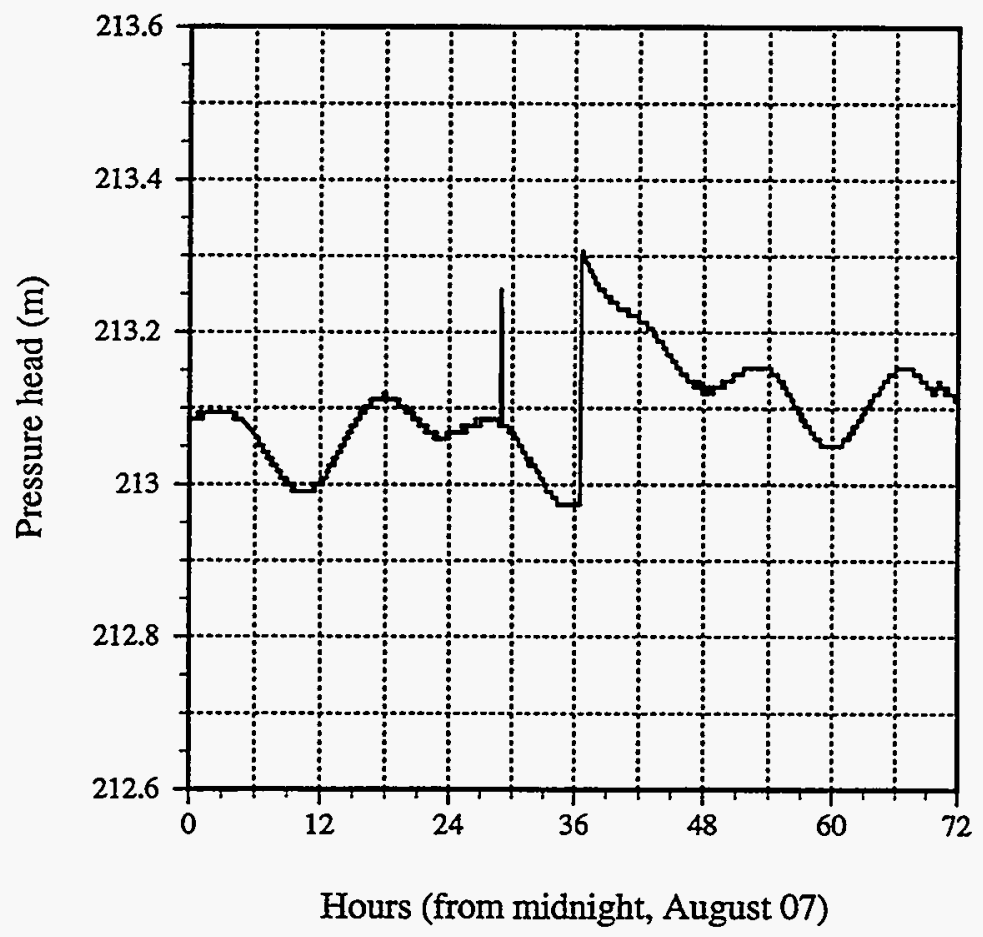

Figure C-12. Groundwater pressure history for Zone 3, August 8 through 10, 1991 


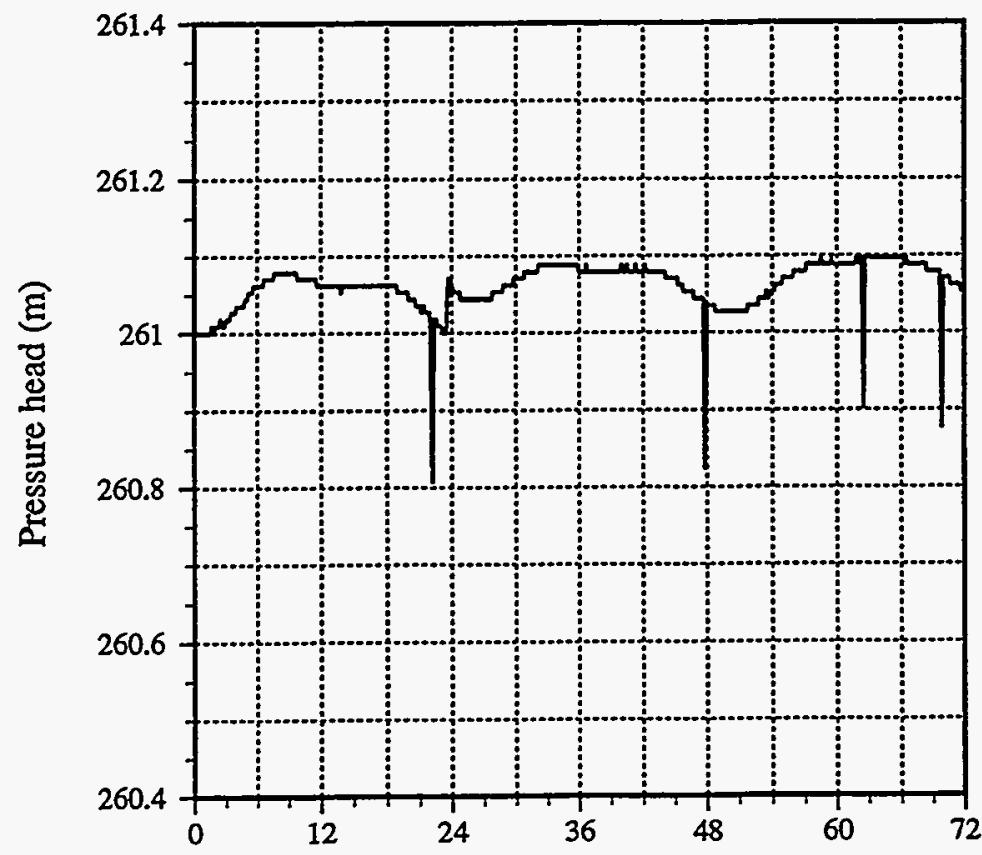

Hours (from midnight, October 10)

Figure C-13. Groundwater pressure history for Zone 1, October 11 through 13, 1991

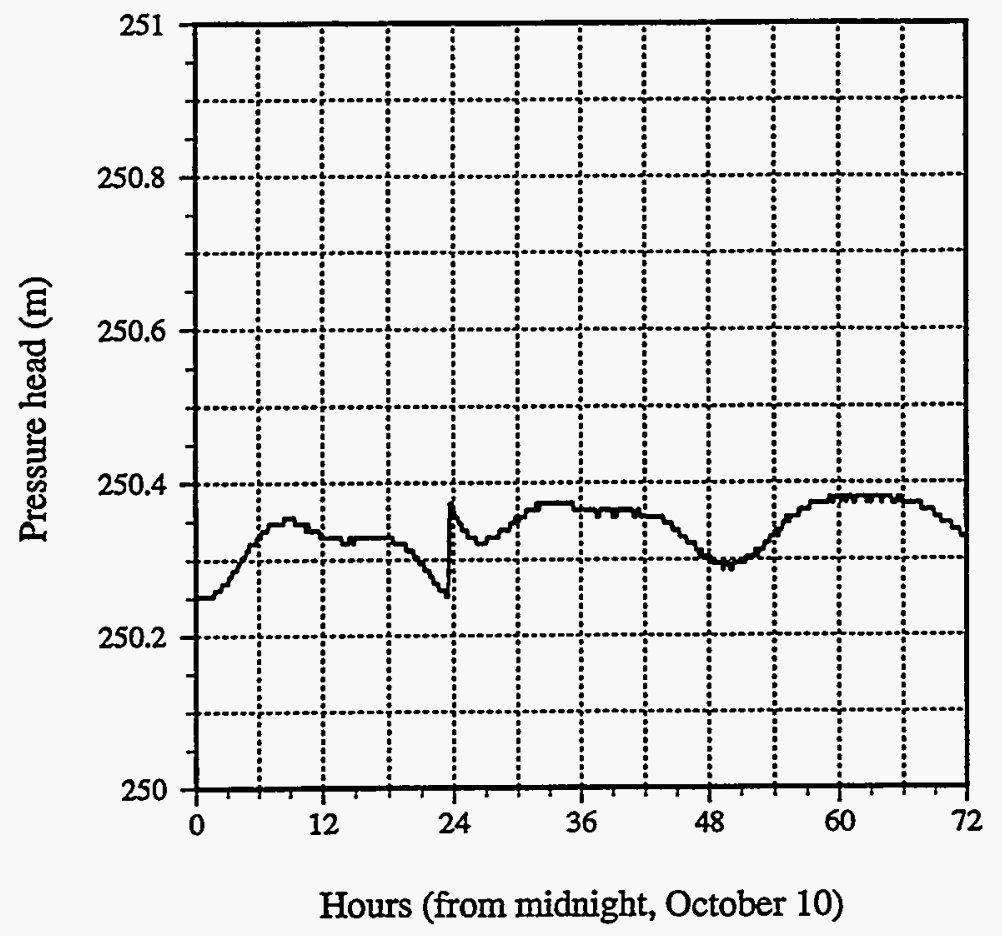

Figure C-14. Groundwater pressure history for Zone 2, October 11 through 13, 1991

C-7

NUREG/CR-6283 


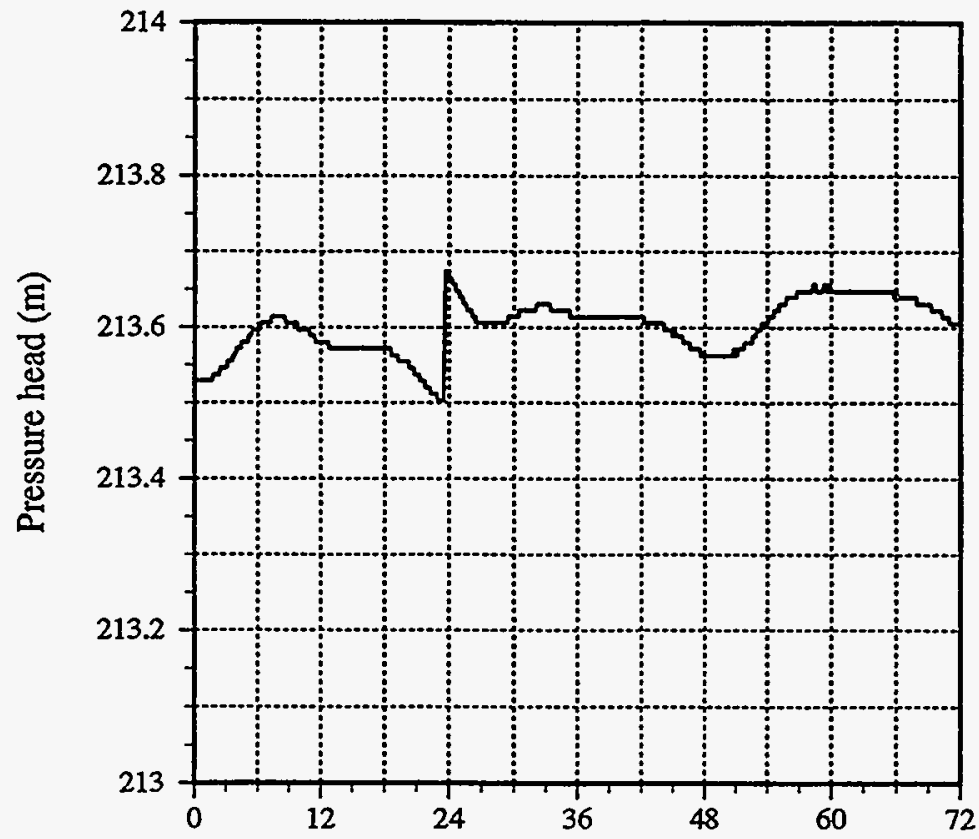

Hours (from midnight, October 10)

Figure C-15. Groundwater pressure history for Zone 3, October 11 through 13, 1991

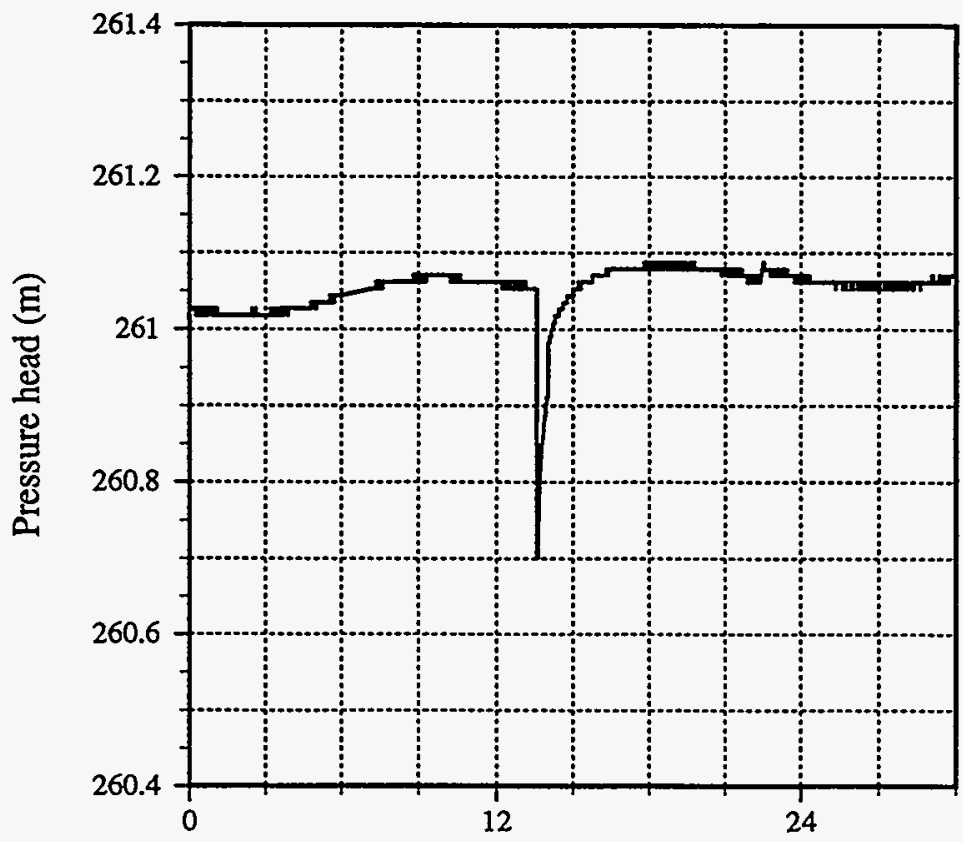

Hours (from midnight, December 10)

Figure C-16. Groundwater pressure history for Zone 1, December 11 through 13, 1991 


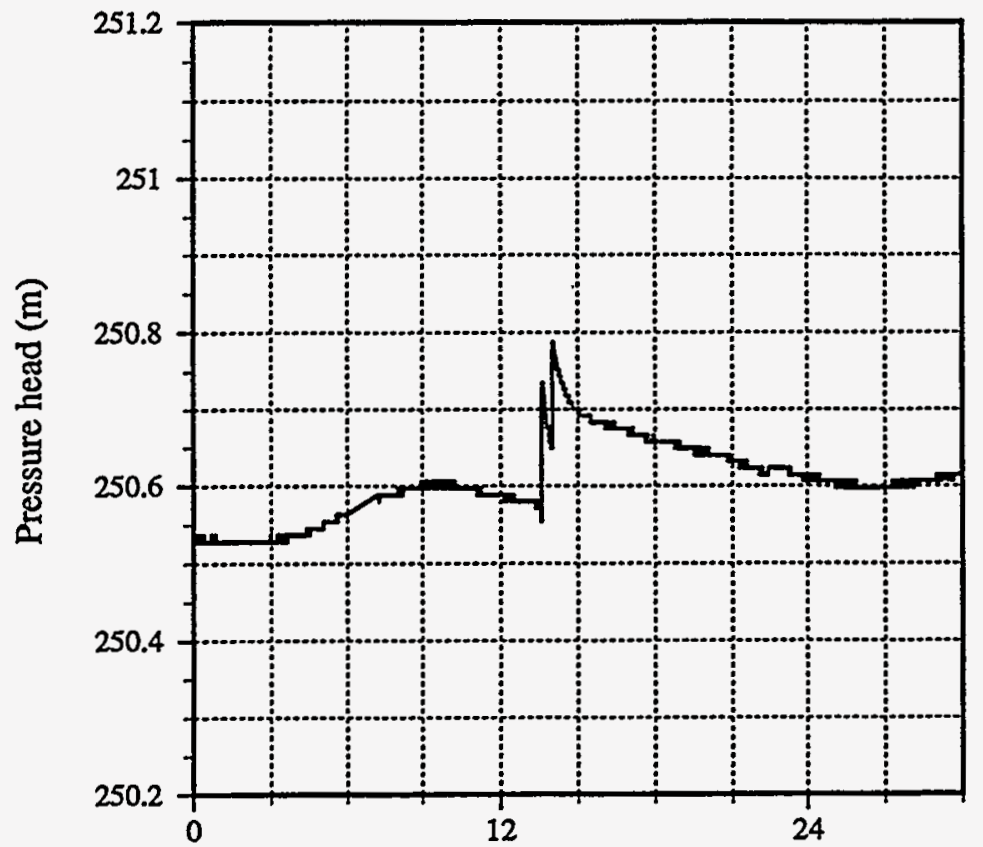

Hours (from midnight, December 10)

Figure C-17. Groundwater pressure history for Zone 2, December 11 through 13, 1991

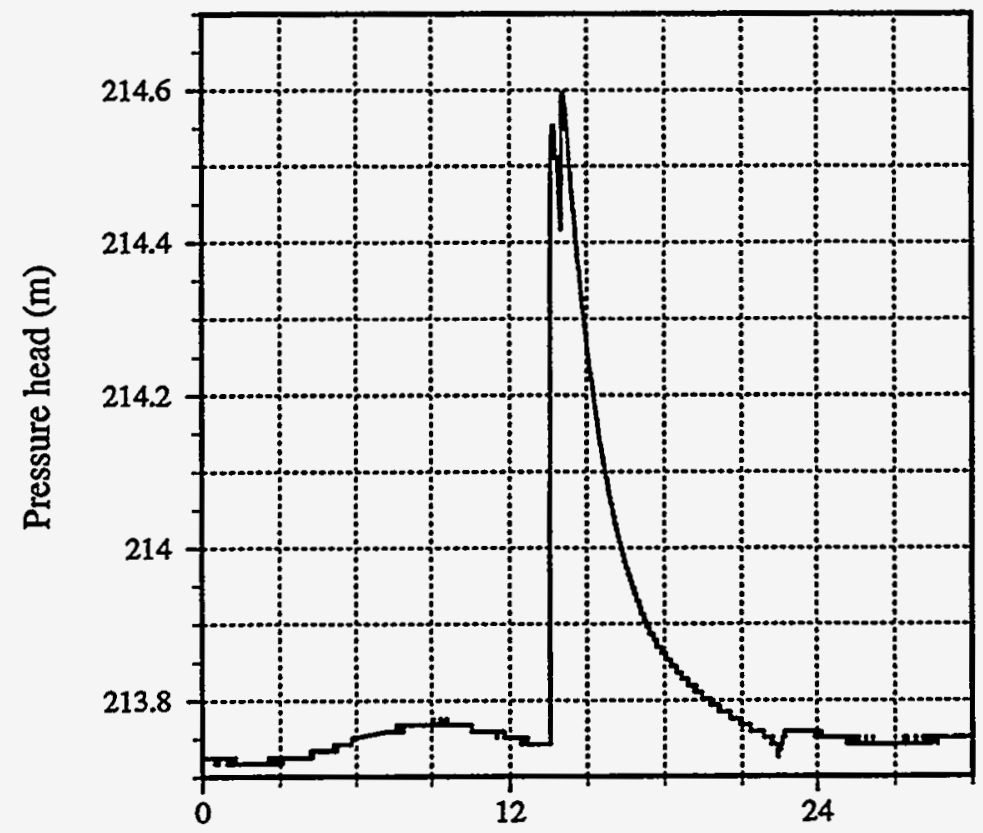

Hours (from midnight, December 10)

Figure C-18. Groundwater pressure history for Zone 3, December 11 through 13, 1991 


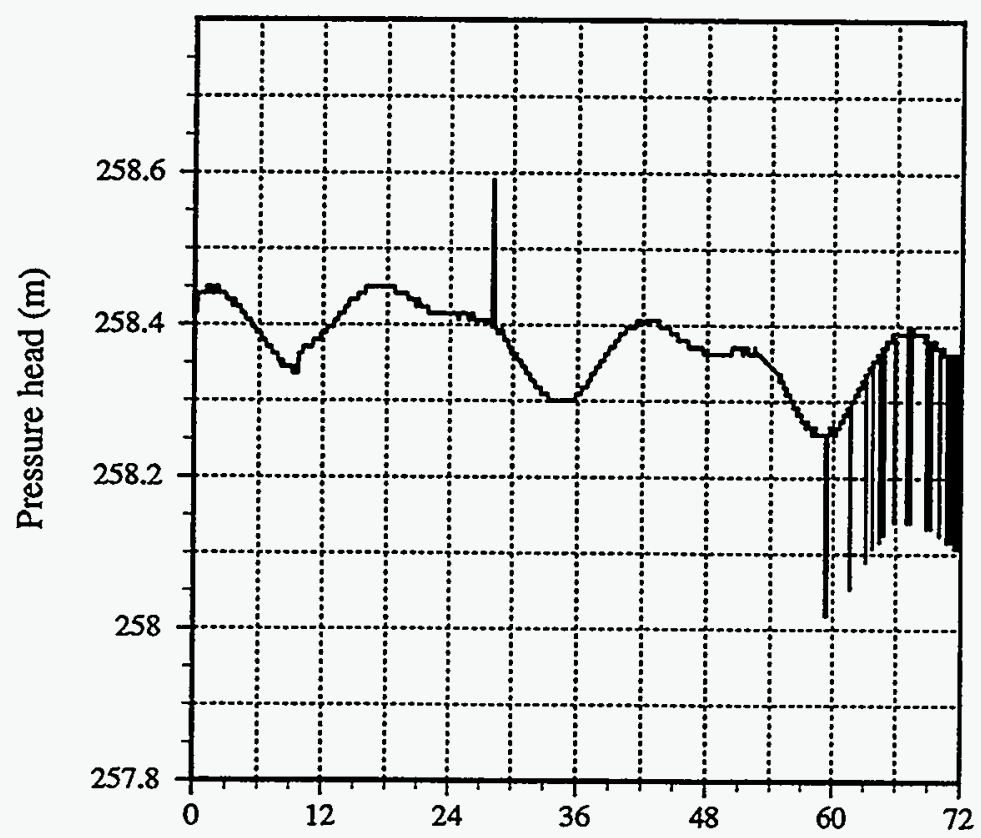

Hours (from midnight, June 26)

Figure C-19. Groundwater pressure history for Zone 1, June 27 through 29, 1992

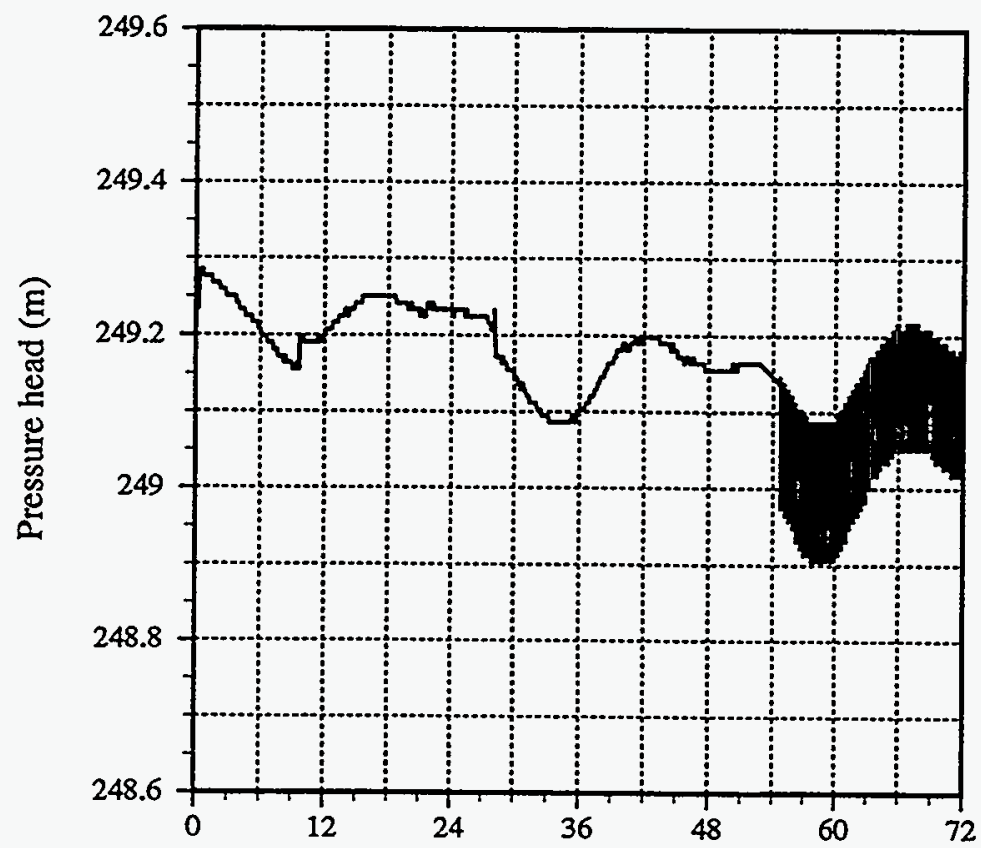

Hours (from midnight, June 26)

Figure C-20. Groundwater pressure history for Zone 2, June 27 through 29, 1992 


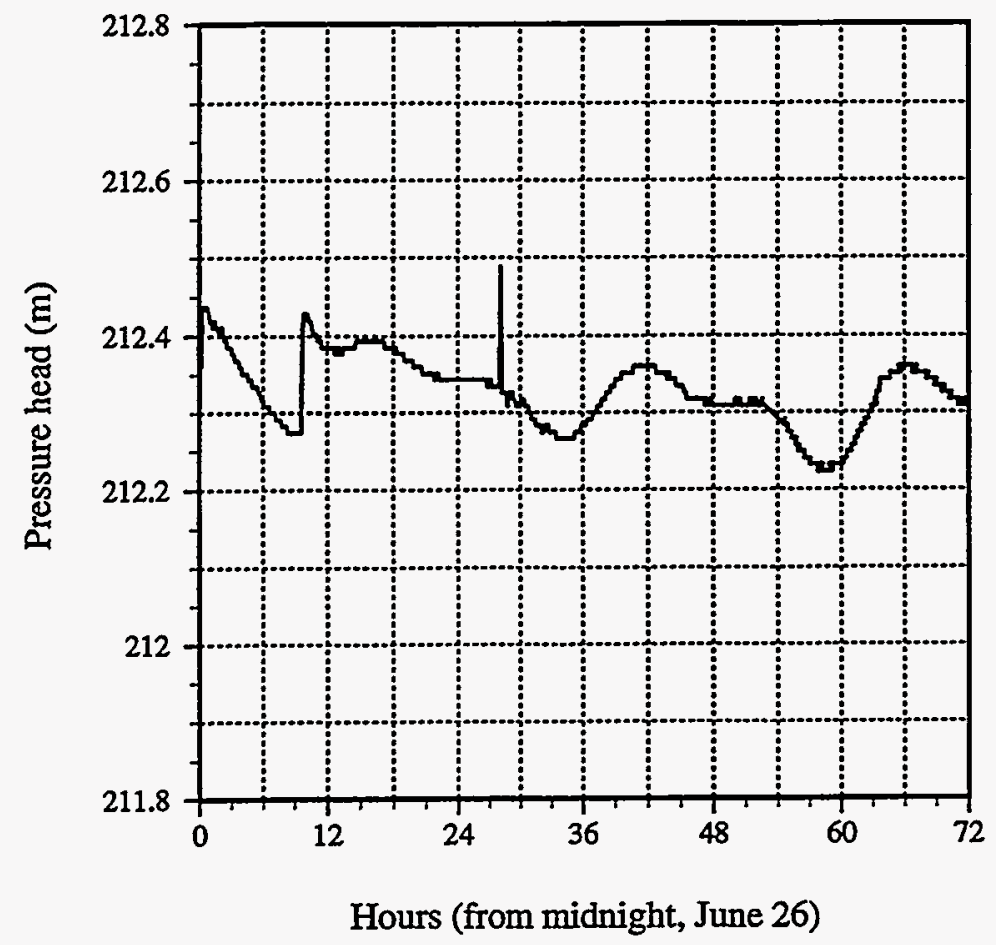

Figure C-21. Groundwater pressure history for Zone 3, June 2' through 29, 1992

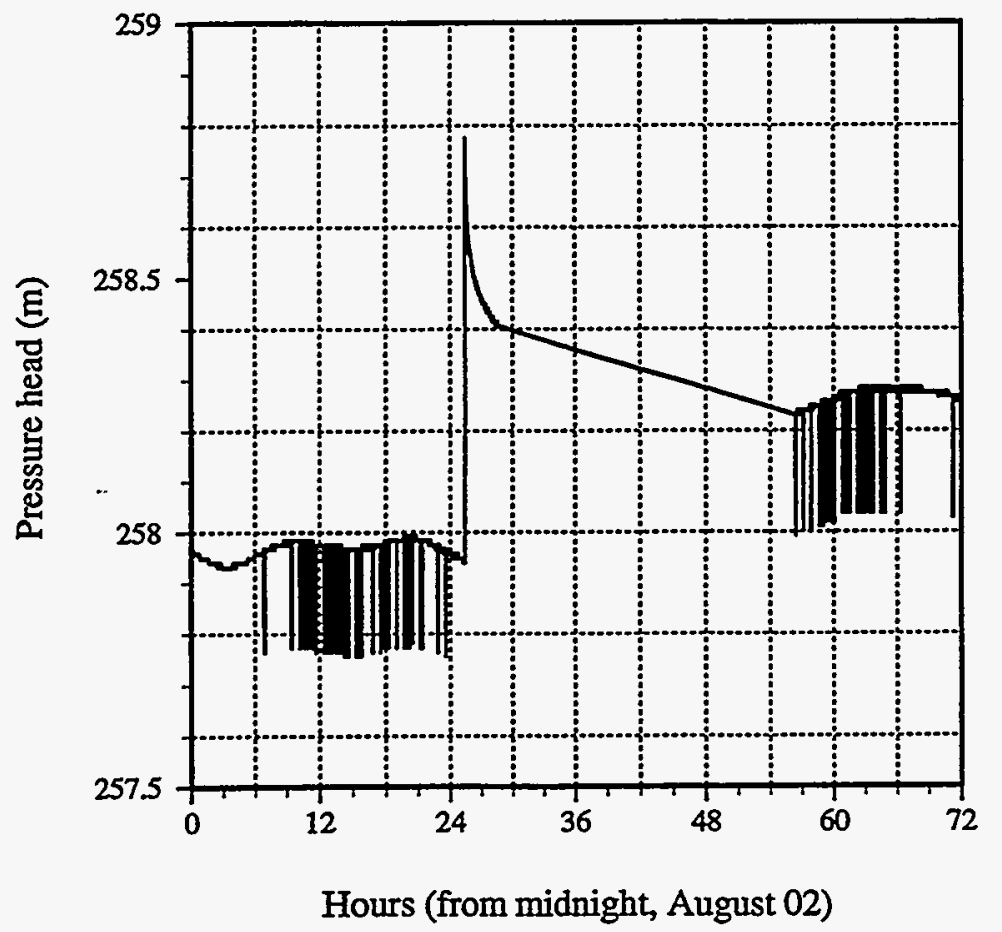

Figure C-22. Groundwater pressure history for Zone 1, August 3 through 5, 1992 


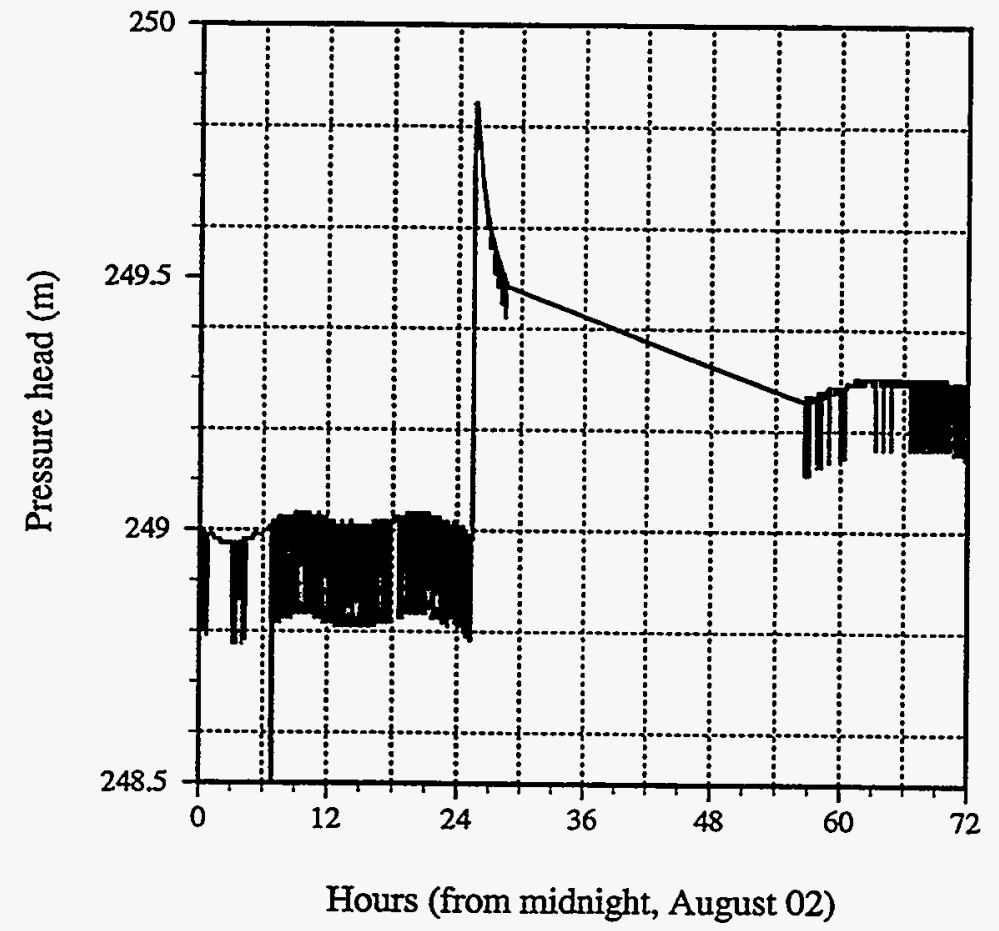

Figure C-23. Groundwater pressure history for Zone 2, August 3 through 5, 1992

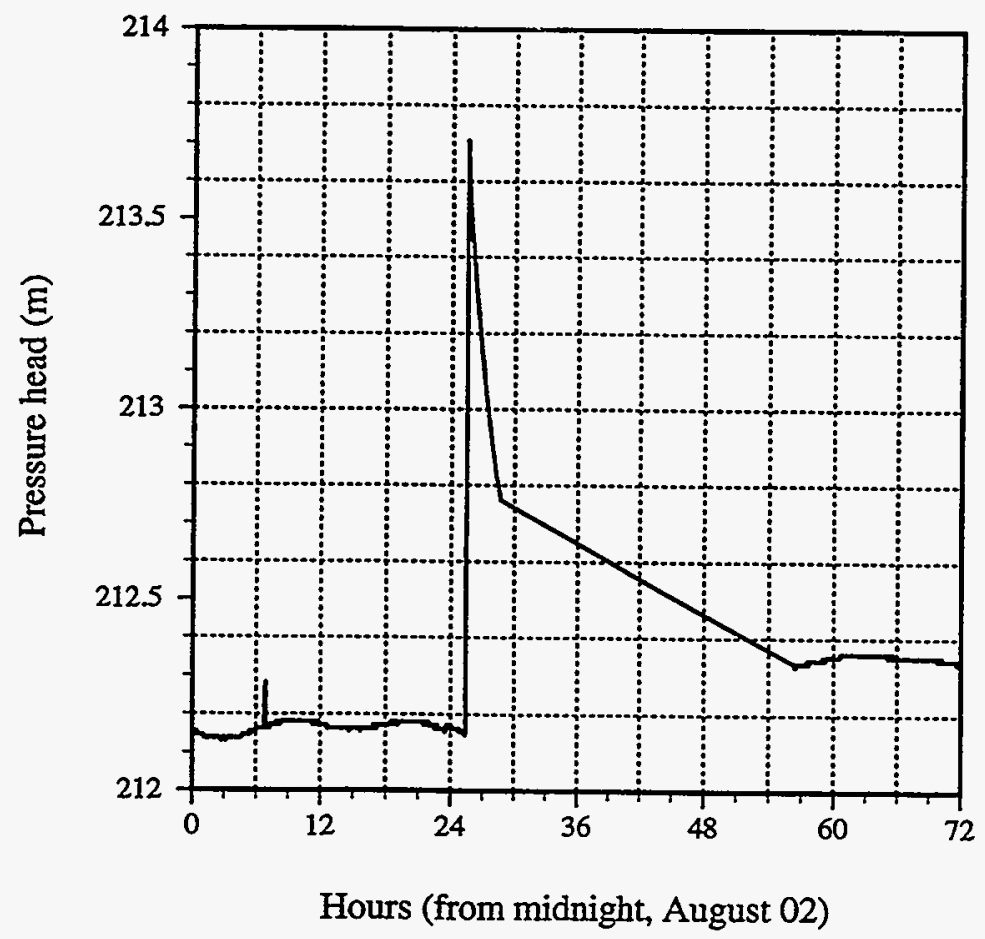

Figure C-24. Groundwater pressure history for Zone 3, August 3 through 5, 1992 


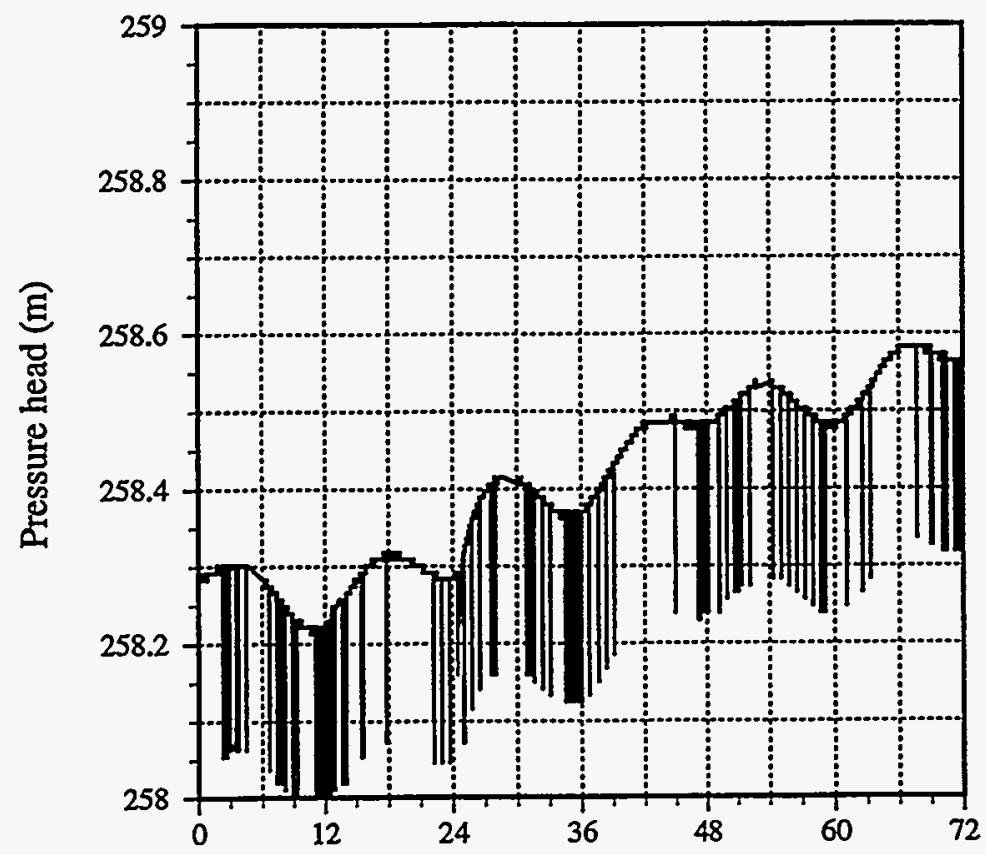

Hours (from midnight, August 10)

Figure C-25. Groundwater pressure history for Zone 1, August 11 through 13, 1992

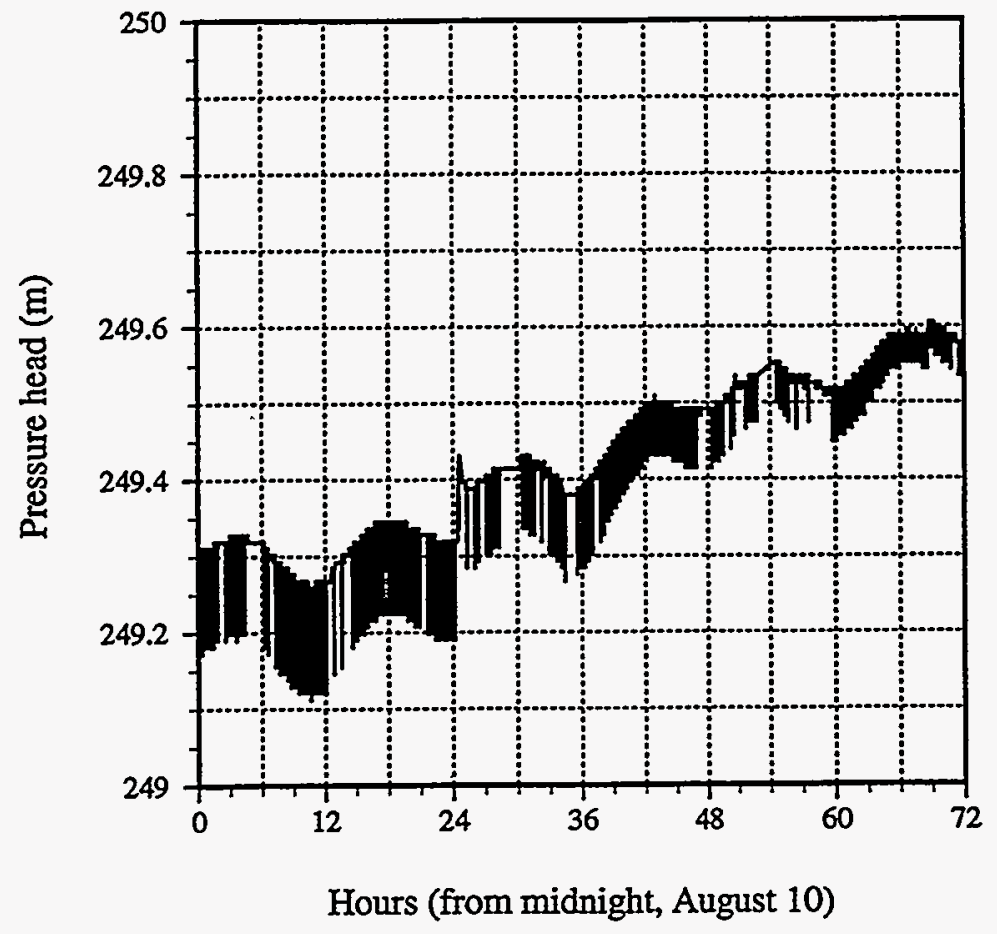

Figure C-26. Groundwater pressure history for Zone 2, August 11 through 13, 1992 


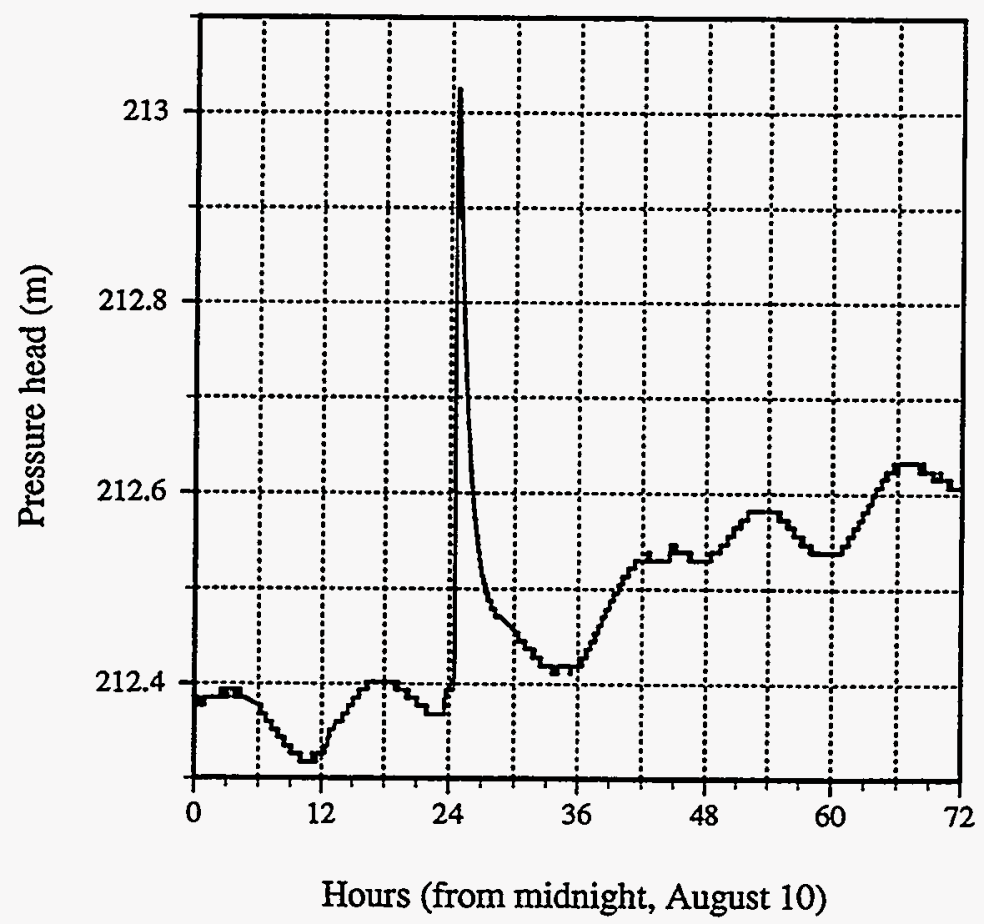

Figure C-27. Groundwater pressure history for Zone 3, August 11 through 13, 1992

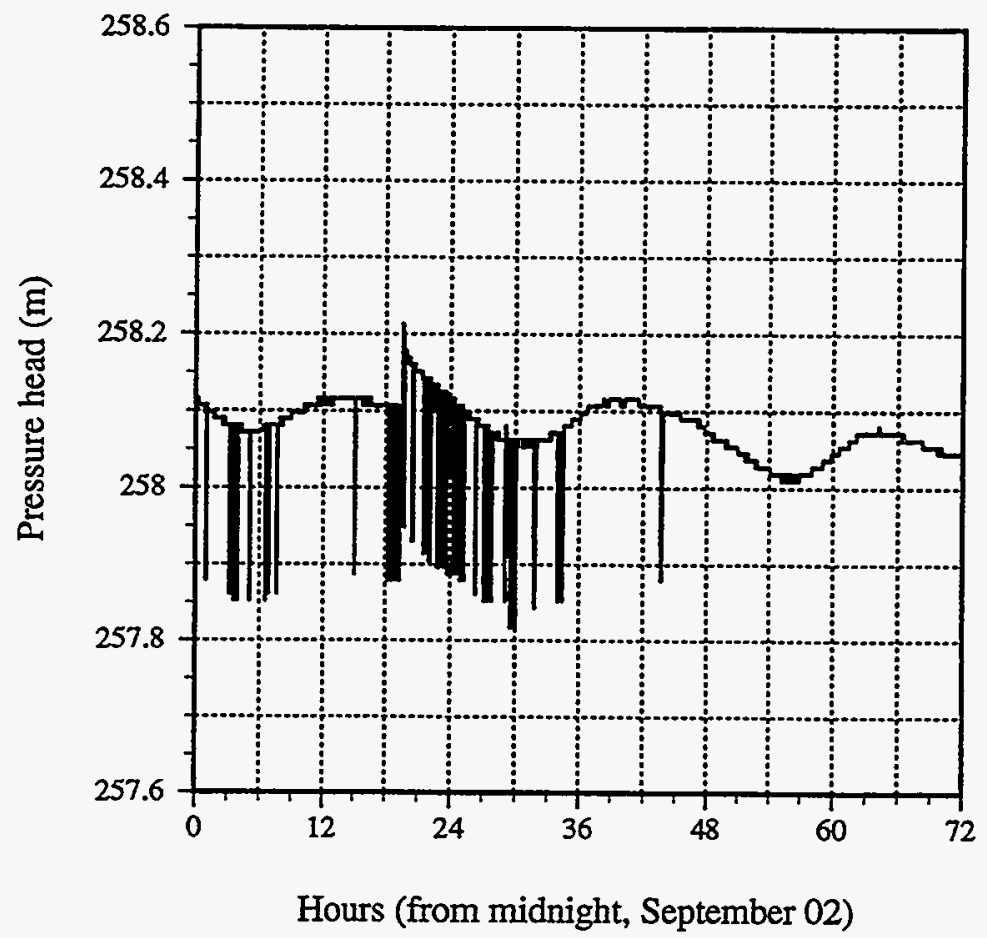

Figure C-28. Groundwater pressure history for Zone 1, September 3 through 5, 1992 


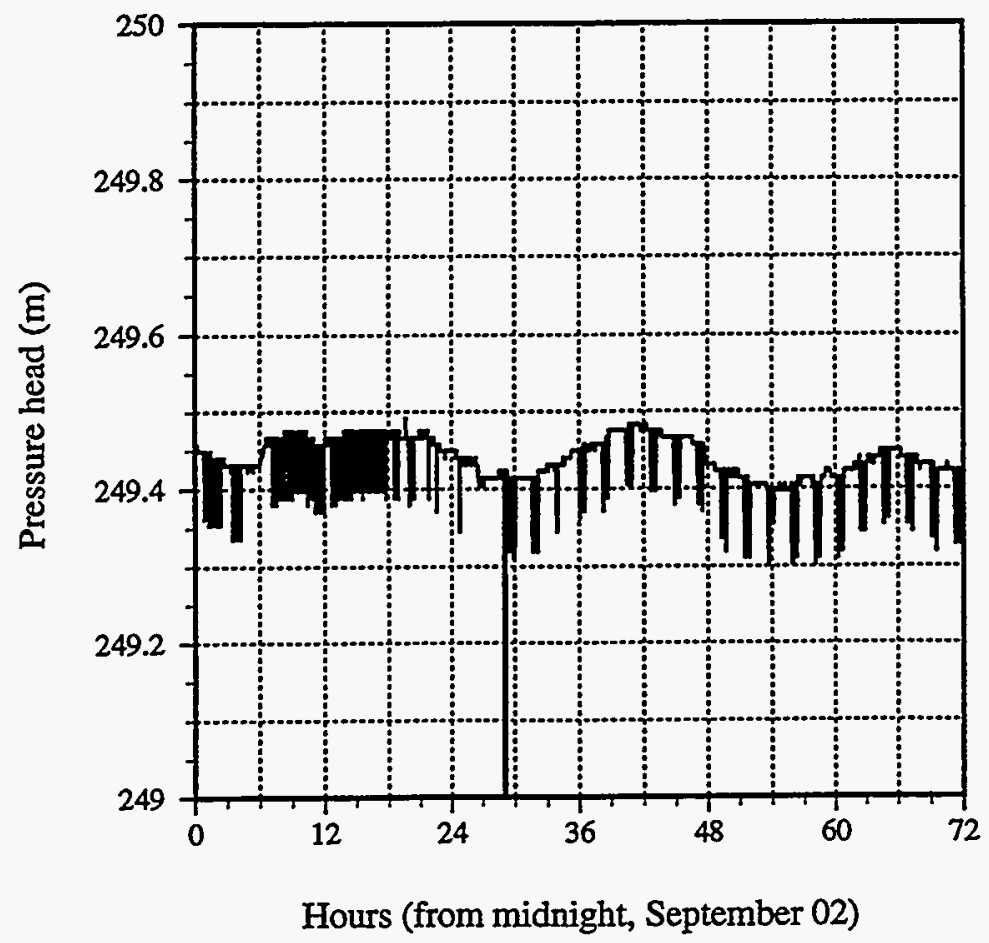

Figure C-29. Groundwater pressure history for Zone 2, September 3 through 5, 1992

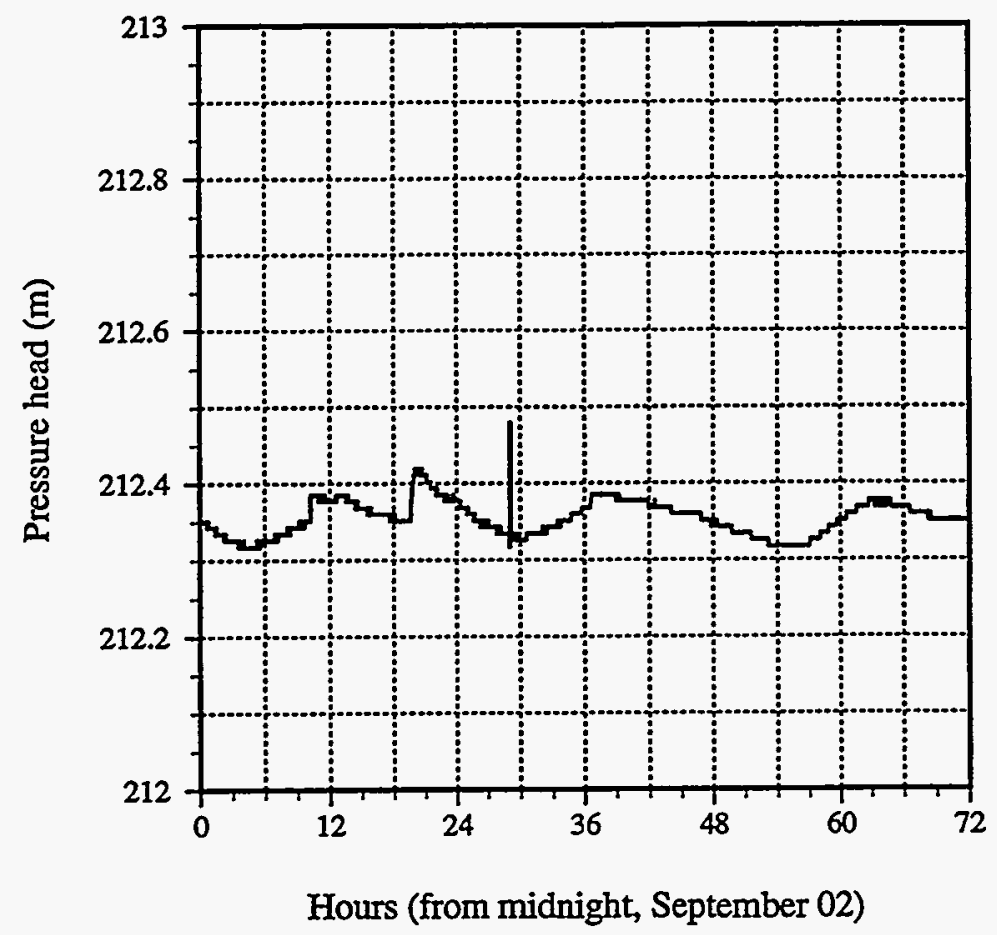

Figure C-30. Groundwater pressure history for Zone 3, September 3 through 5, 1992 


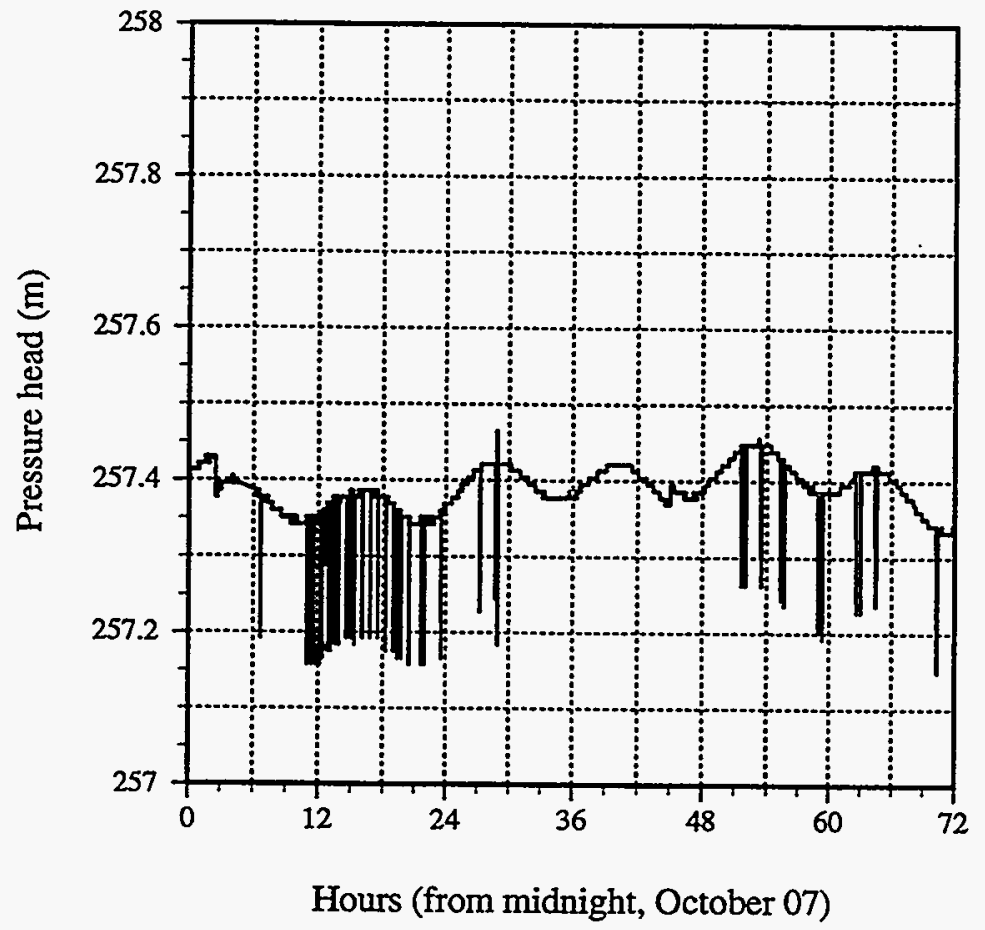

Figure C-31. Groundwater pressure history for Zone 1, October 8 through 10, 1992

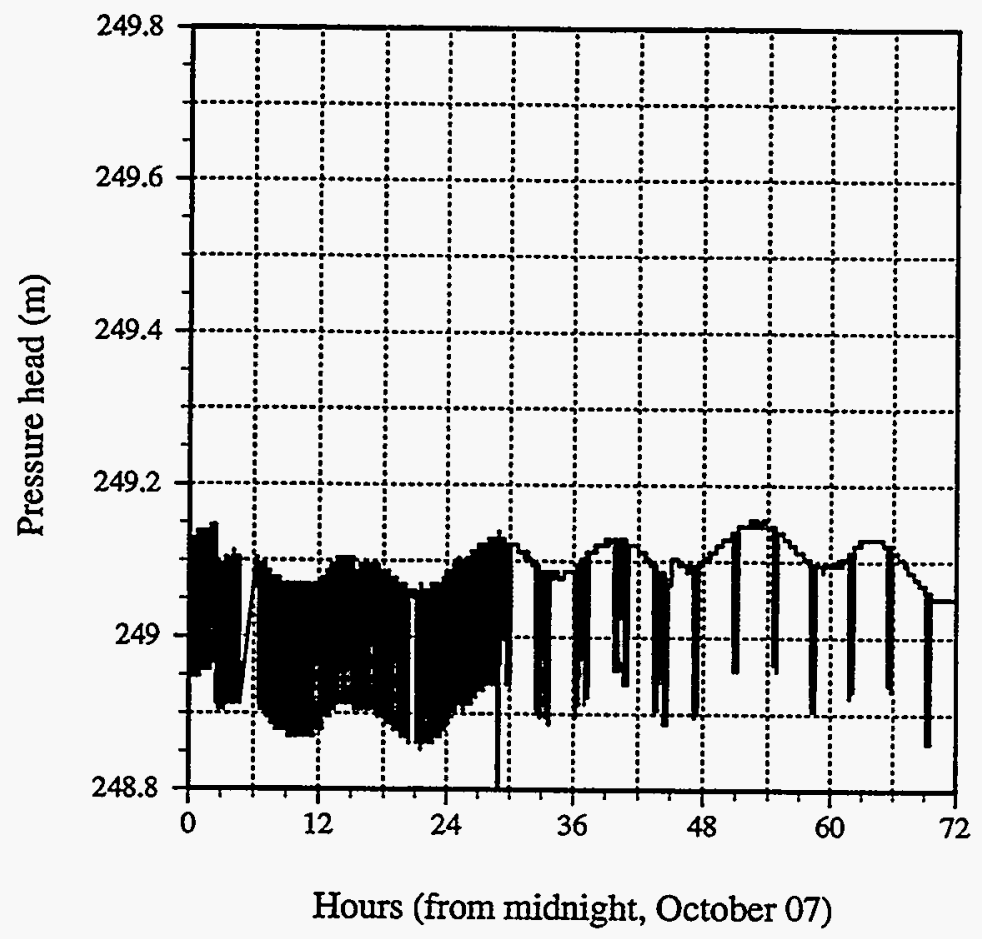

Figure C-32. Groundwater pressure history for Zone 2, October 8 through 10, 1992 


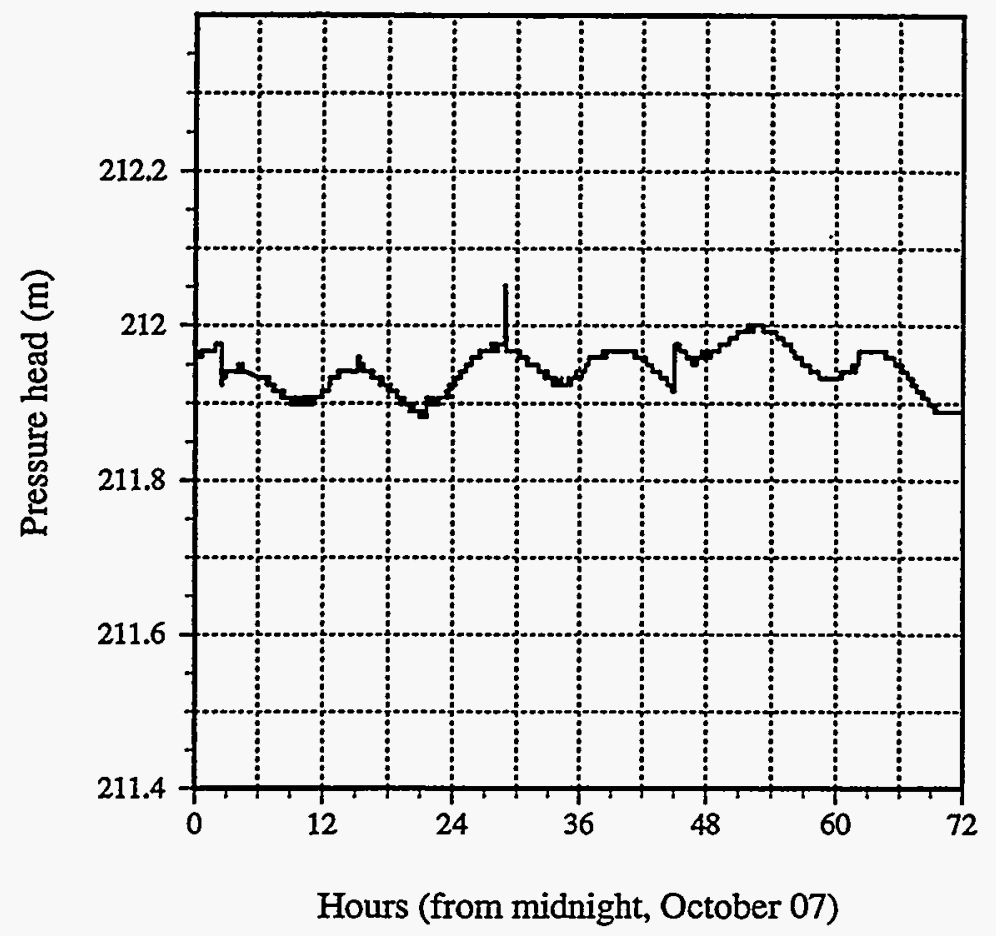

Figure C-33. Groundwater pressure history for Zone 3, October 8 through 10, 1992

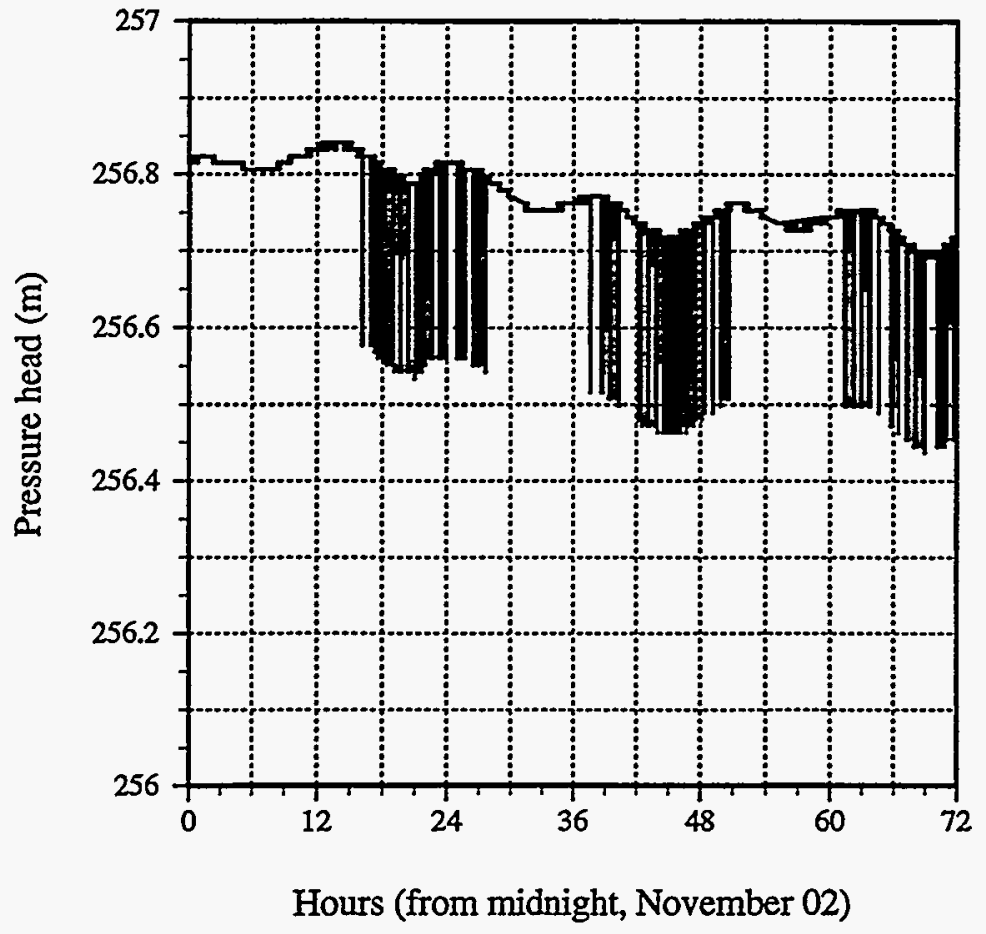

Figure C-34. Groundwater pressure history for Zone 1, November 3 through 5, 1992 


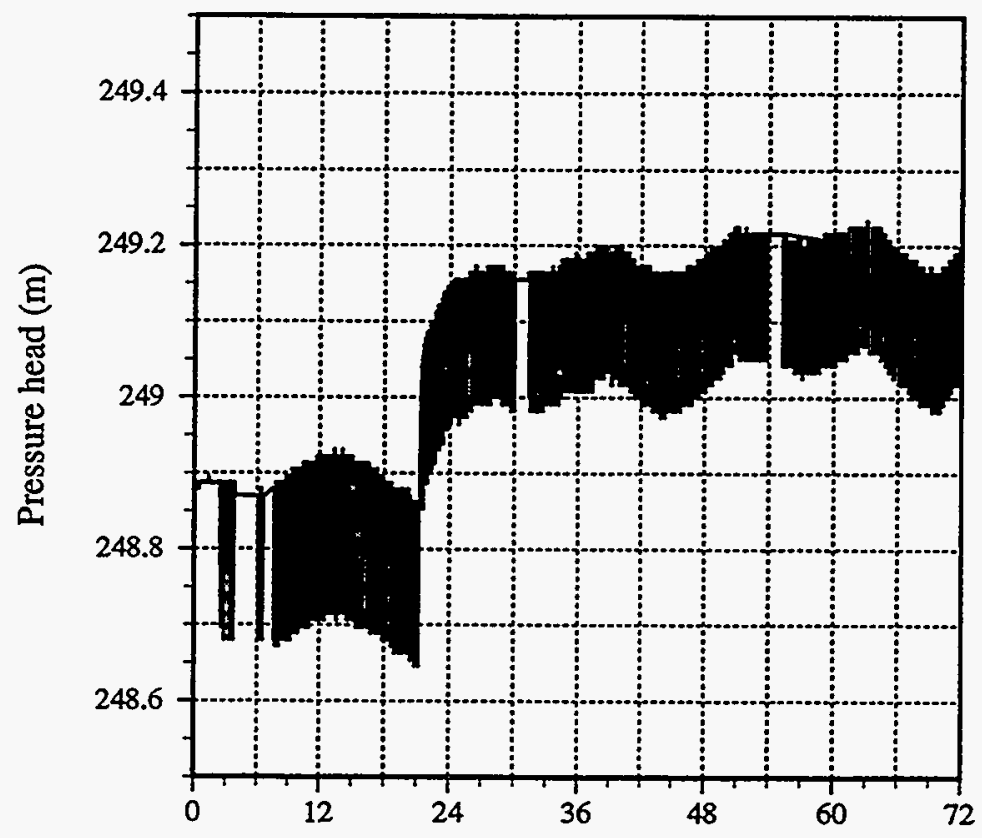

Hours (from midnight, November 02)

Figure C-35. Groundwater pressure history for Zone 2, November 3 through 5, 1992

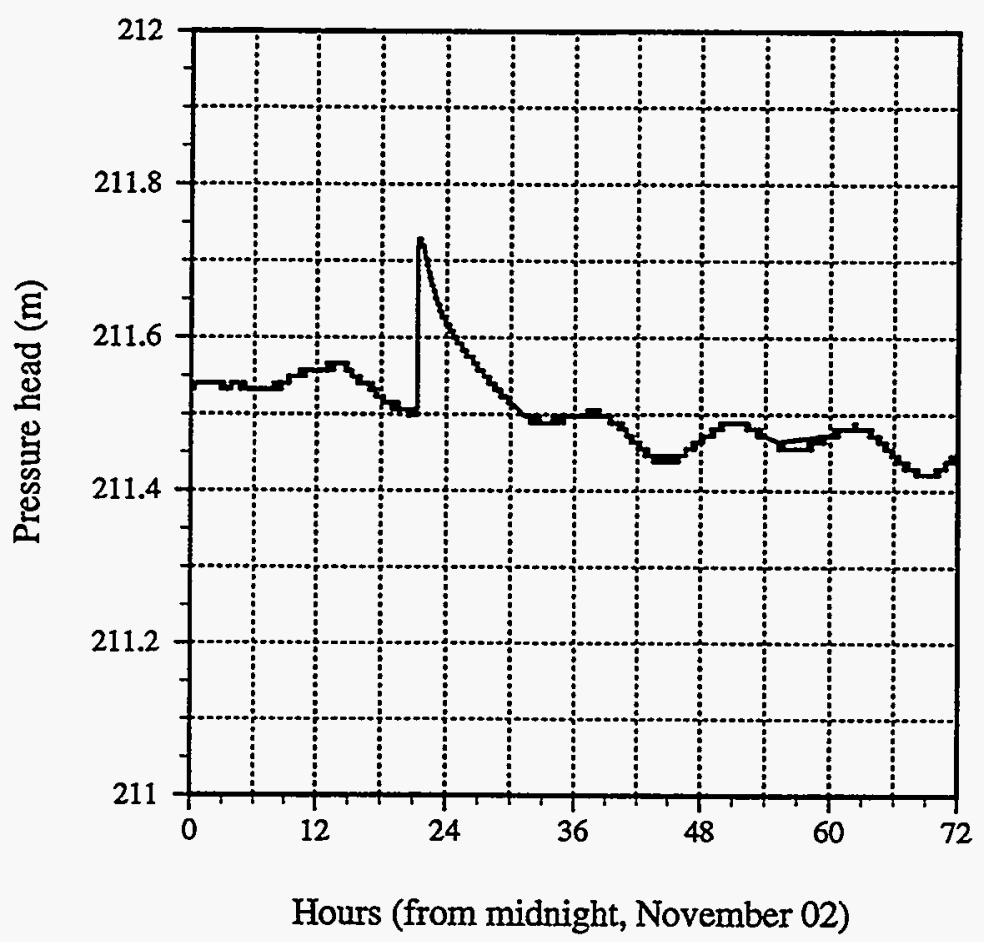

Figure C-36. Groundwater pressure history for Zone 3, November 3 through 5, 1992 


\begin{tabular}{|c|c|}
\hline $\begin{array}{l}\text { NRC FORM } 335 \\
\text { (2.89) } \\
\text { NRCM 1102. } \\
3201,3202\end{array}$ & $\begin{array}{l}\text { U.S. NUCLEAR REGULATORY COMMISSION } \\
\text { BIBLIOGRAPHIC DATA SHEET } \\
\text { (See instructions on the reverse) }\end{array}$ \\
\hline
\end{tabular}

2. TITLE AND SUBTITLE
1. REPORT NUMBER

(Assigned by NRC. Add Vol.s Susp., Rev., and Addendum Numbers, if any.)

NUREG/CR-6283

CNWRA 94-017

FIELD SITE INVESTIGATION: EFFECT OF MINE SEISMICITY ON GROUNDWATER HYDROLOGY

5. AUTHOR(S)

Goodluck I. Ofoegbu, Sui-Min Hsiung, Asadul H. Chowdlumry (CNWRA) and Jacob Philip (NRC)
3.

DATE REPORT PUBLISHED

Apri 7

4. FIN OR GRANT NUMBER

FINB6643

6. TYPE OF REPORT

Technical
7. PERIOD COVERED /Inclusive DatesI

B. PERFORMING ORGANIZATION - NAME AND ADDRESS IIf NRC, provide Division, Office or Region, U.S. Nuclear Regulatory Commission, and mailing address; if contractor, provide name and malling address)

Center for Nuclear Waste ReguTatory Analyses

6220 Culebra Road

San Antonio, TX 78238-5166

9. SPONSORING ORGANIZATION - NAME AND ADDRESS IIf NRC, type "Same as above"; if contractor, provide NRC Division, Office or Region, U.S. Nuclear Regulatory Commission, and malling address.)

Division of Regulatory Applications, RES

U.S. Nuclear Regulatory Commission

Washington, DC 20555 - 0001

\section{SUPPLEMENTARY NOTES}

\section{ABSTRACT (200 words or less)}

The results of a field investigation on the groundwater-hydrologic effect of mining-induced earthquakes are presented. The investigation was conducted at the Lucky Friday Mine ldaho. the groundwater pressure in three fracture zones was monitored over a 24-mo period. The magnitude, source location. and associated ground motions of mining-induced seismic events were also monitored.

Several seismic events of magnitude 1.0 or larger were recorded, many of which caused a change in the groundwater pressure. The magnitude of groundwater-pressure change varied with the seismic-event magnitude and source distance. The data was examined using regression analysis. The statistical models obtained predicted the effects of small-magnitude seismic events more satisfactorily than those of larger ones. The observed change in groundwater pressure due to seismic events of magnitude 3.0 or more were larger than those predicted using the statistical models.

Based on these results, it is suggested that the effect of earthquakes on groundwater flow may be better understood through mechanistic modeling. The mechanical processes and material behavior that would need to be incorporated in such a model are examined. They include a description of the effect of stress change on the perneability and water storage capacity of a fractured rock mass; transient fluid flow; and the generation and transmission of seismic waves through the rock mass.

\begin{tabular}{|c|}
\hline $\begin{array}{l}\text { 13. AVAILABILITY STATEMENT } \\
\text { Unl imited }\end{array}$ \\
\hline 14. SECURITY CLASSIFICATION \\
\hline $\begin{array}{l}\text { (This Pagel } \\
\text { Unclassified }\end{array}$ \\
\hline $\begin{array}{l}\text { (This Report } \\
\text { Uniclassified }\end{array}$ \\
\hline 15. NUMBER OF PAGES \\
\hline 16. PRICE \\
\hline
\end{tabular}

